\title{
New and little known taxa of Platerotini, with a note on biogeography of the tribe (Coleoptera: Lycidae)
}

\author{
Новые и малоизвестные таксоны Platerotini, с замечанием \\ по биогеографии трибы (Coleoptera: Lycidae)
}

\author{
Sergey V. Kazantsev \\ С.В.Казанцев
}

Insect Centre, Donetskaya 13-326, Moscow 109651, Russia

Инсект-центр, ул. Донецкая 13-326, Москва, 109651, Россия, e-mail: kazantss@mail.ru

KEY WORDS: Coleoptera, Lycidae, Platerotini, Paraplateros, Plateros, new species, synonymy, taxonomy. КЛЮЧЕВЫЕ СЛОВА: Coleoptera, Lycidae, Platerotini, Paraplateros, Plateros, новые виды, синонимия, таксономия.

ABSTRACT. A new genus, Euplateros gen.n., and sixty nine new species are described in Platerotini: Euplateros viridimontis, E. poasensis, E. guanacastensis, Teroplas montiviridis, T. tishechkini, T. petrovi, Paraplateros metagalpaensis, Cavoplateros victoriensis (Central and South America), Falsotrichalus bukitensis, F. haedus, F. luchti, F. slametensis (Great Sunda Islands), Plateros nantouensis, P. obrienorum (Taiwan), P. bengalensis, P. burmensis, P. karnaliensis, $P$. myanmarensis, $P$. putaoensis, $P$. weigeli (Himalayas), P. belokobylskyi, $P$. cinis, $P$. cochinensis, $P$. deinceps, P. dulcis, P. faber, P. fedorenkoi, P. igneus, $P$. innitidus, $P$. integer, $P$. kabakovi, $P$. kradungensis, P. laocaensis, $P$. loeiensis, $P$. merulus, $P$. nanensis, $P$. nemo, $P$. nonus, $P$. orlovi, $P$. pulverulentus, $P$. subplanatus, $P$. tenebrosus (Indochina), $P$. bruggei, $P$. grootaerti, $P$. holynskiorom, $P$. indentatus, $P$. madangensis, $P$. makarovi, $P$. novaguineensis, $P$. papuaensis, P. rufosuturalis, P. villosopenis (New Guinea), P. cacaophilus, $P$. cerberus, $P$. nigripennis, $P$. papilio, $P$. parallelipennis, $P$. hephaestus (Costa Rica), P. amazonensis, $P$. lugubris, $P$. mosolovi, $P$. nautaensis, $P$. piger, $P$. pirana, $P$. speciosus, $P$. tartarus, $P$. tiputiniensis, $P$. yasuniensis and $P$. zakharovi (Ecuador and Peru), spp.n. Paraplateros Zaragoza, 1999, stat.n. is raised to the genus level. Euplateros calanticatoides (Kazantsev, 2005), comb.n. and E. discolor (Kazantsev, 2005), comb.n. are transferred to Euplateros gen.n. from Plateros Bourgeois, 1879. Plateros hoanus (Pic, 1926), syn.n. and P. pallidus (Pic, 1921), syn.n. are synonymized with $P$. planatus Waterhouse, 1879, and P. rocioae Zaragoza, 1999, syn.n. - with $P$. tumacacori Green, 1953. The following replacement names are proposed in Plateros: P. afroguineensis nom.n. pro $P$. guineensis Kazantsev, 1997, nec P. guineensis (Pic, 1921); $P$. alitecostatus nom.n. pro $P$. diversecostatus Pic, 1942, nec $P$. diversecostatus (Pic, 1922); P. angus nom.n. pro $P$. angustatus (Pic, 1939), nec $P$. angustatus (Pic, 1926); P. antennifer nom.n. pro P. antennalis
Kleine 1930, nec $P$. antennalis Bourgeois, 1882; $P$. atrosuturalis nom.n. pro $P$. nigrosuturalis (Kleine, 1931), nec P. nigrosuturalis (Pic, 1921); P. balabacensis nom.n. pro $P$. balabacanus (Pic, 1929), nec $P$. balabacanus (Pic, 1921); P. bicoloricrus nom.n. pro $P$. bicoloripes Pic, 1943, nec P. bicoloripes (Pic, 1923); P. bocakovae nom.n. pro P. prominens (Bocakova, 1997), nec $P$. prominens Kleine, 1940; P. brunneorufus nom.n. pro $P$. rufobrunneus (Gorham, 1882), nec $P$. rufobrunneus (Gorham, 1881); P. caballeroi nom.n. pro $P$. aterrimus Zaragoza, 1999, nec $P$. aterrimus (Gorham, 1884); P. ciceroi nom.n. pro P. tonkineus (Pic, 1931), nec $P$. tonkineus Pic, 1926; $P$. constantini nom.n. pro $P$. marseuli (Pic, 1934), nec P. marseuli Pic, 1923; $P$. cristifer nom.n. pro $P$. pectinicornis (Pic, 1932), nec $P$. pectinicornis Pic, 1923; P. curtilinaris nom.n. pro $P$. curtelineatus (Pic, 1934), nec P. curtelineatus Pic, 1926; P. duomaculatus nom.n. pro P. bimaculatus Pic, 1922, nec $P$. bimaculatus (Kirsch, 1873); P. elegans nom.n. pro $P$. mundus Kleine, 1949, nec $P$. mundus (Kleine, 1931); P. gorhamianus nom.n. pro $P$. gorhami Zaragoza, 1999, nec P. gorhami (Pic, 1921); P. fuliganus nom.n. pro $P$. fuliginosus (Pic, 1934), nec $P$. fuliginosus Kleine, 1930; P. hoabinhensis nom.n. pro P. binhanus Pic, 1925, nec P. binhanus (Pic, 1925); P. laditatus nom.n. pro $P$. dilatatus (Bocakova, 1997), nec $P$. dilatatus (Pic, 1926); P. maculaticrus nom.n. pro $P$. maculatipes (Pic, 1934), nec P. maculatipes (Pic, 1926); $P$. mauricei nom.n. pro $P$. donckieri (Pic, 1934), nec $P$. donckieri (Pic, 1923); P. miladae nom.n. pro P. gressitti (Bocakova, 1997), nec P. gressitti Nakane, 1971; P. nakanei nom.n. pro $P$. latevittatus Nakane, 1983, nec P. latevittatus (Pic, 1934); P. nigrosutus nom.n. pro $P$. nigrosuturalis Kleine, 1939, nec $P$. nigrosuturalis (Pic, 1921); P. parabolus nom.n. pro P. parallelus (Pic, 1928), nec P. parallelus Gorham, 1880; P. pullatus nom.n. pro $P$. nigricolor Pic, 1943 , nec $P$. nigricolor (Pic, 1932); P. reductefasciatus nom.n. pro P. subfasciatus (Pic, 1934), nec P. subfasciatus (Pic, 1930); P. 
semang nom.n. pro P. malaccanus (Pic, 1928), nec $P$. malaccanus (Pic, 1921); P. simulus nom.n. pro $P$. simulator Kazantsev, 2005, nec $P$. simulator Kleine, 1929; P. subductor nom.n. pro P. subreductus (Pic, 1942), nec P. subreductus (Pic, 1934); P. sumatrensis nom.n. pro $P$. longipennis (Pic, 1926), nec P. longipennis (Pic, 1921); P. suturalissimus nom.n. pro P. longesuturalis (Pic, 1932), nec P. longesuturalis (Pic, 1921); $P$. villosus nom.n. pro $P$. pilosus (Pic, 1934), nec $P$. pilosus Kleine, 1926 and $P$. zaragozai nom.n. pro $P$. falcatus Zaragoza, 1999, nec P. falcatus (Bocakova, 1997). Lectotypes are designated for Plateros bifoveiceps (Pic, 1921), P. donckieri (Pic, 1923), P. hoanus (Pic, 1926), P. nathani Pic, 1943, P. nitidus Pic, 1938 and P. pallidus (Pic, 1921).

РЕЗЮМЕ. В статье описывается новый род, Euplateros gen.n., и шестьдесят девять новых видов краснокрылов из трибы Platerotini: Euplateros viridimontis, E. poasensis, E. guanacastensis, Teroplas montiviridis, T. tishechkini, T. petrovi, Paraplateros metagalpaensis, Cavoplateros victoriensis (Центральная и Южная Америка), Falsotrichalus bukitensis, F. haedus, F. luchti, F. slametensis (Большие Зондские острова), Plateros nantouensis, P. obrienorum (Тайвань), $P$. bengalensis, $P$. burmensis, $P$. karnaliensis, $P$. myanmarensis, $P$. putaoensis, $P$. weigeli (Гималаи), $P$. belokobylskyi, $P$. cinis, $P$. cochinensis, $P$. deinceps, $P$. dulcis, $P$. faber, $P$. fedorenkoi, $P$. igneus, $P$. innitidus, P. integer, P. kabakovi, P. kradungensis, P. laocaensis, P. loeiensis, $P$. merulus, $P$. nanensis, $P$. nemo, $P$. nonus, $P$. orlovi, $P$. pulverulentus, $P$. subplanatus, $P$. tenebrosus (Индокитай), P. bruggei, P. grootaerti, P. holynskiorum, $P$. indentatus, $P$. madangensis, $P$. makarovi, $P$. novaguineensis, $P$. papuaensis, $P$. rufosuturalis, $P$. villosopenis (Новая Гвинея), P. cacaophilus, P. cerberus, $P$. nigripennis, $P$. papilio, $P$. parallelipennis, $P$. hephaestus (Коста-Рика), P. amazonensis, P. lugubris, P. mosolovi, P. nautaensis, $P$. pirana, $P$. piger, $P$. speciosus, $P$. tartarus, $P$. tiputiniensis, $P$. yasuniensis и $P$. zakharovi (Эквадор и Перу) spp.n. Повышается статус Paraplateros Zaragoza, 1999, stat.n. до родового уровня. Euplateros calanticatoides (Kazantsev, 2005), comb.n. и E. discolor (Kazantsev, 2005), comb.n. переносятся в Euplateros gen.n. из Plateros Bourgeois, 1879. Plateros hoanus (Pic, 1926), syn.n. и P. pallidus (Pic, 1921), syn.n. сводятся в синонимы к P. planatus Waterhouse, 1879, а $P$. rocioae Zaragoza, 1999, syn.n. - к P. tumacacori Green, 1953. В роде Plateros предлагаются замещающие названия: P. afroguineensis nom.n. pro $P$. guineensis Kazantsev, 1997, nec P. guineensis (Pic, 1921); $P$. alitecostatus nom.n. pro $P$. diversecostatus Pic, 1942, nec $P$. diversecostatus (Pic, 1922); P. angus nom.n. pro $P$. angustatus (Pic, 1939), nec $P$. angustatus (Pic, 1926); P. antennifer nom.n. pro P. antennalis Kleine 1930, nec $P$. antennalis Bourgeois, 1882; $P$. atrosuturalis nom.n. pro $P$. nigrosuturalis (Kleine, 1931), nec P. nigrosuturalis (Pic, 1921); P. balabacensis nom.n. pro P. balabacanus (Pic, 1929), nec P. balabacanus (Pic, 1921); P. bicoloricrus nom.n. pro $P$. bicoloripes Pic, 1943, nec P. bicoloripes (Pic, 1923); P. bocakovae nom.n. pro P. prominens (Bocakova, 1997), nec $P$. prominens Kleine, 1940; $P$. brunneorufus nom.n. pro $P$. rufobrunneus (Gorham, 1882), nec $P$. rufobrunneus (Gorham, 1881); P. caballeroi nom.n. pro $P$. aterrimus Zaragoza, 1999, nec $P$. aterrimus (Gorham, 1884); P. ciceroi nom.n. pro P. tonkineus (Pic, 1931), nec P. tonkineus Pic, 1926; P. constantini nom.n. pro $P$. marseuli (Pic, 1934), nec P. marseuli Pic, 1923; P. cristifer nom.n. pro P. pectinicornis (Pic, 1932), nec $P$. pectinicornis Pic, 1923; P. curtilinaris nom.n. pro $P$. curtelineatus (Pic, 1934), nec $P$. curtelineatus Pic, 1926; P. duomaculatus nom.n. pro $P$. bimaculatus Pic, 1922, nec P. bimaculatus (Kirsch, 1873); P. elegans nom.n. pro P. mundus Kleine, 1949, nec $P$. mundus (Kleine, 1931); P. gorhamianus nom.n. pro $P$. gorhami Zaragoza, 1999, nec P. gorhami (Pic, 1921); P. fuliganus nom.n. pro P. fuliginosus (Pic, 1934), nec $P$. fuliginosus Kleine, 1930; $P$. hoabinhensis nom.n. pro $P$. binhanus Pic, 1925, nec $P$. binhanus (Pic, 1925); P. laditatus nom.n. pro P. dilatatus (Bocakova, 1997), nec P. dilatatus (Pic, 1926); $P$. maculaticrus nom.n. pro P. maculatipes (Pic, 1934), nec P. maculatipes (Pic, 1926); P. mauricei nom.n. pro P. donckieri (Pic, 1934), nec P. donckieri (Pic, 1923); P. miladae nom.n. pro P. gressitti (Bocakova, 1997), nec $P$. gressitti Nakane, 1971; $P$. nakanei nom.n. pro $P$. latevittatus Nakane, 1983, nec P. latevittatus (Pic, 1934); $P$. nigrosutus nom.n. pro $P$. nigrosuturalis Kleine, 1939, nec P. nigrosuturalis (Pic, 1921); P. parabolus nom.n. pro $P$. parallelus (Pic, 1928), nec $P$. parallelus Gorham, 1880; P. pullatus nom.n. pro $P$. nigricolor Pic, 1943, nec $P$. nigricolor (Pic, 1932); $P$. reductefasciatus nom.n. pro $P$. subfasciatus (Pic, 1934), nec $P$. subfasciatus (Pic, 1930); P. semang nom.n. pro $P$. malaccanus (Pic, 1928), nec P. malaccanus (Pic, 1921); $P$. simulus nom.n. pro P. simulator Kazantsev, 2005, nec $P$. simulator Kleine, 1929; $P$. subductor nom.n. pro P. subreductus (Pic, 1942), nec P. subreductus (Pic, 1934); P. sumatrensis nom.n. pro P. longipennis (Pic, 1926), nec $P$. longipennis (Pic, 1921); P. suturalissimus nom.n. pro $P$. longesuturalis (Pic, 1932), nec $P$. longesuturalis (Pic, 1921); P. villosus nom.n. pro P. pilosus (Pic, 1934), nec P. pilosus Kleine, 1926 и P. zaragozai nom.n. pro P. falcatus Zaragoza, 1999, nec P. falcatus (Bocakova, 1997). Обозначаются лектотипы для Plateros bifoveiceps (Pic, 1921), P. donckieri (Pic, 1923), P. hoanus (Pic, 1926), P. nathani Pic, 1943, $P$. nitidus Pic, 1938 и $P$. pallidus (Pic, 1921).

\section{Introduction}

Quite a number of papers dealing with the Platerotini fauna of various regions were published recently [e.g., Bocáková, 1997a, 1997b, 2001; Zaragoza, 1999; Kazantsev, 1991, 1997, 2000, 2001, 2004, 2005a, 2005b, $2006 \mathrm{a}, 2006 \mathrm{~b}$, etc.], bringing the number of species described in Plateros Bourgeois, 1879 alone to over 800. Despite this, every new entomological expedition to primary forests in tropical lands seems to bring more 
new forms than already known ones. Descriptions of some of these new taxa, as well as certain taxonomic notes are presented below.

The following acronyms are used in the paper: AMNH - American Museum of Natural History, New York; ICCM - Insect Center Collection, Moscow; IRSN - Institut Royal de Sciences naturelles de Belgique, Bruxelles; LSAM — Louisiana State University Arthropod Museum, Baton Rouge; MNHN — Muséum national d'Histoire naturelle, Paris; NKME - Naturkundemuseum, Erfurt; ZMAU — Zoological Museum of Amsterdam University.

\section{Taxonomy}

\section{Euplateros Kazantsev gen.n.}

Type species: Plateros calanticatoides Kazantsev, 2005

DESCRIPTION. Male. Elongate. Head transverse. Fastigium acute. Labrum transverse, rectangular, slightly emarginate medially. Eyes moderately large, spherical. Mandibles small, strongly curved inwards. Maxillary and labial palps slender, with ultimate palpomeres widened and convex distally. Gena absent. Antennal prominence conspicuous, contiguous, antennal sockets separated by minute lamina. Antennae 11-segmented, moderately long, attaining to elytral two thirds, antennomeres 3-11 flattened, but nearly parallelsided (Figs 1, 5-6); antennomere 3 more than 2 times shorter than antennomere 4; pubescence of antennomeres 3-11 uniform, dense and erect.

Pronotum transverse, short, with prominent, produced latero-posteriorly posterior angles, smooth, with dense vestiture (Figs 1, 5-6). Prosternum short, triangular, concave anteriorly. Mesothoracic spiracles well developed, but not protruding beyond propleuron. Mesosternum transverse, with concave anterior margin. Mesepimeron narrow, only slightly shorter than mesepisternum. Postnotal plate of scutellum small, elongate, nearly parallel-sided. Elytra long, flattened and conspicuously widened behind shoulders, separately rounded at apices, with four equally developed primary costae, except conspicuously elevated near humerus costa 4; interstices with irregular double rows of cells; pubescence short and erect. Discrimen (metasternal suture) long, almost attaining to mesoventrite. Metathoracic wing $C u$ veins connected to $M$; wedge cell absent; cu-a brace below $\mathrm{Cu}$ veins fork.

Mesocoxae subquadrate, separated. Legs moderately long; trochanters elongate, distally straight; femurs and tibiae flattened; tibiae straight, only slightly convex proximally, with a pair of minute spurs. Tarsi small, tarsomeres 1 and 2 narrow, not lobed, with apical plantar pad; all claws simple. Abdomen with eight ventrites; terminal ventrite symmetric. Abdominal spiracles located dorsally at the edge of sternite. Aedeagus with elongate straight median lobe; parameres absent; phallobase broad, roundish, not compressed laterally, without visible sutures (Figs 3-4, 7-11).

Female. Similar to male, but eyes somewhat smaller and antennomeres 3-10 somewhat wider. Abdomen with seven ventrites. Genitalia with two accessory glands; styli, coxites and valvifers sclerotised; styli noticeably shorter than coxites; coxites and valvifers slender, rigidly attached to each other; spermatheca long, strongly curved twice (Fig. 4).

DIAGNOSIS. Euplateros gen.n. is readily distinguishable from Plateros by the flattened and broadened elytra with conspicuously raised fourth (humeral) costa and irregular rows of cells in the interstices (Figs 1, 5-6), as well as by the roundish and not compressed laterally phallobase of the aedeagus (Figs 3-4, 7-11) and slender coxites and valvifers and long, strongly curved spermatheca of the female genitalia (Fig. 4).

ETYMOLOGY. The name is derived from the Latin for "good" and "Plateros", the name of a genus, with which the new taxon has resemblance, alluding to its much smaller number of species. Gender masculine.

DISTRIBUTION. Central America. So far known only from Costa Rica, where, in addition to the three species described below, there also occur E. calanticatoides (Kazantsev, 2005), comb.n. (Figs 1-4), the type species of the genus, and E. discolor (Kazantsev, 2005), comb.n. (Fig. 5), previously listed in Plateros.

\section{Euplateros viridimontis Kazantsev sp.n. Figs 6-8}

MATERIAL: Holotype, $\sigma^{7}$, Costa Rica, Monteverde, 15001800 m, 15-20.IV.2003, S. Kazantsev leg. (ICCM); paratype, +, same label (ICCM).

DESCRIPTION. Male. Black. Lateral margins of pronotum broadly ochre.

Head dorsally coarsely and densely punctured, with small triangular impression behind antennal prominence, antennal sockets separated by minute lamina. Eyes small (separated medially above by about 2.7 times their radius). Ultimate maxillary palpomere small, elongate, almost parallel-sided, convex at apex. Antennae narrow, extending to over two thirds of elytra, from antennomere 3 flattened, but parallelsided; antennomere 3 about 1.25 times longer than antennomere 2 and 3 times shorter than antennomere 4; antennomeres 3-11 with short erect pubescence and several long distal bristles.

Pronotum transverse, trapezoidal, 1.6 times wider than long, with rounded anterior and prominent rounded posterior angles; anterior margin almost straight; posterior margin bisinuate (Fig. 6). Scutellum elongate, narrowing distally, slightly emarginate at apex.

Elytra long, 3.3 times as long as wide humerally and 5.9 times longer than pronotum, widest in middle, with four equally developed, except at humerus, primary costae; interstices with double rows of irregular cells (Fig. 6). Pubescence uniform, short and dense.

Aedeagus with straight, narrow, widened distally median lobe (Figs 7-8).

Female. Similar to male, but somewhat broader, antennomeres slightly wider.

Length: 9.2-10.8 mm. Width (humerally): $2.3-3.1 \mathrm{~mm}$; (at elytral middle): $3.8-4.7 \mathrm{~mm}$.

ETYMOLOGY. The name of the new species is derived from the Latin for Monteverde, the area in Puntarenas, Costa Rica, where the type series was collected.

DIAGNOSIS. E. viridimontis sp.n. is similar to $E$. discolor, distinguishable by the black pronotal disk (Fig. 6), as well as by the more widened distally median lobe of the aedeagus (Figs 7-8).

\section{Euplateros poasensis Kazantsev sp.n. Figs $8-10$}

MATERIAL: Holotype, $\sigma^{\top}$, Costa Rica, Vulcan Poas, 23002400 m, 7-12.IV.2003, S. Kazantsev leg. (ICCM).

DESCRIPTION. Male. Black. Lateral margins of pronotum broadly ochre.

Head dorsally coarsely and densely punctured, with prominent triangular impression behind antennal prominence, antennal sockets separated by minute lamina. Eyes small (separated 

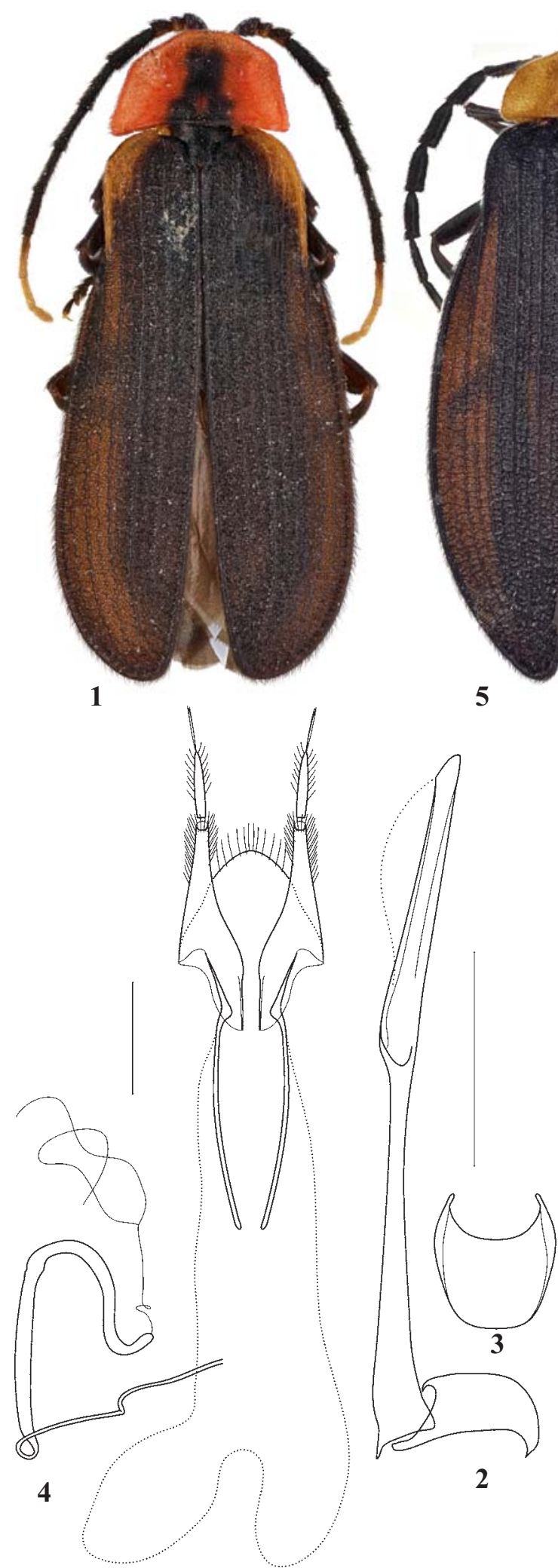

2

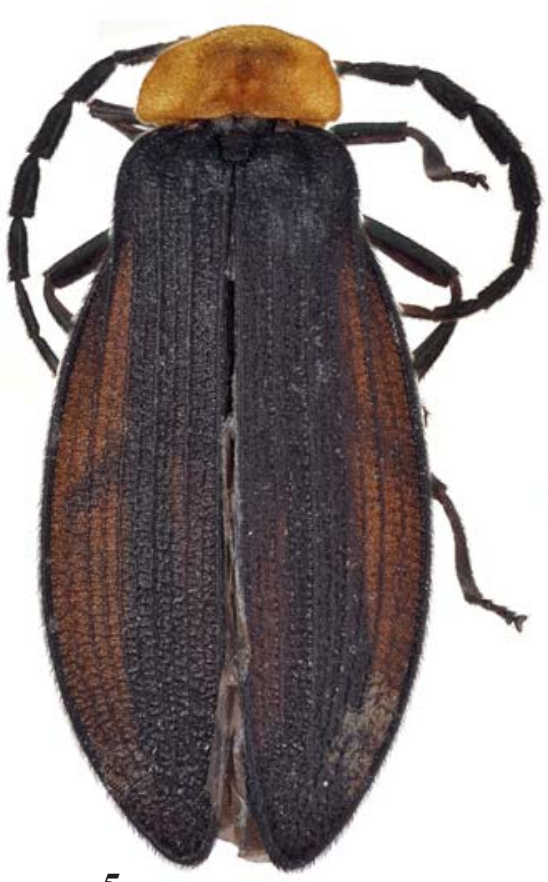

5

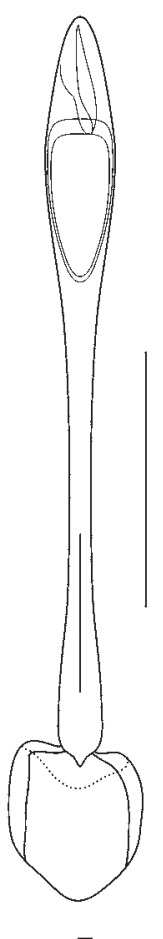

7

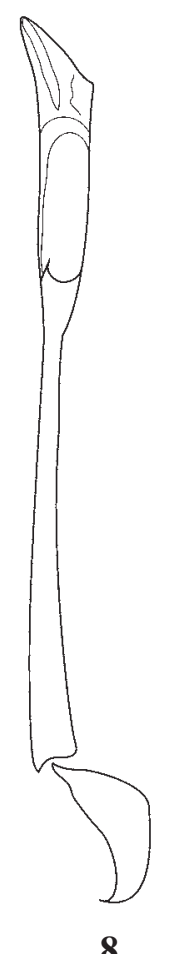

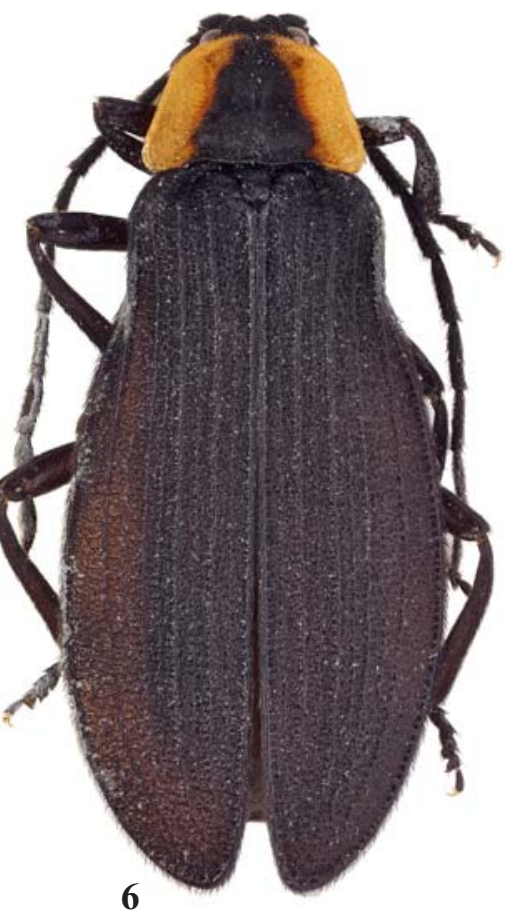

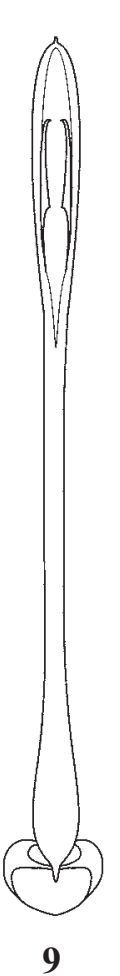

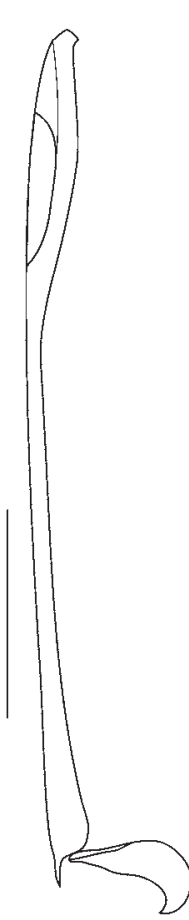

10

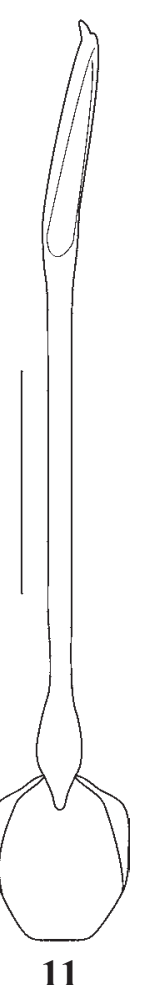

11

Figs 1-11. General view and aedeagi of Euplateros gen.n. spp.: $1-4-$ E. calanticatoides $(1=8.0 \mathrm{~mm}) ; 5-E$. discolor $(1=10.2 \mathrm{~mm}) ; 6-$ $8-$ E. viridimontis sp.n. $(1=10.7 \mathrm{~mm}) ; 8-10-$ E. poasensis sp.n.; $11-$ E. guanacastensis sp.n.; $1,5-6-$ general view; $2,7-11-$ aedeagus; 3 - phallobase; 4 - female genitalia; 1, 4-6 - paratypes females; 2-3, 7-8 - paratypes males; 8-11 - holotypes males. Scale bar: 5 mm.

Рис. 1-11. Общий вид и эдеагусы Euplateros gen.n. spp.: 1-4-E. calanticatoides $(1=8.0$ мм $)$; 5 - E. discolor $(1=10.2$ мм); 6-8 E. viridimontis sp.n. $(1=10.7$ мм $) ; 8-10-$ E. poasensis sp.n.; $11-$ E. guanacastensis sp.n.; 1, 5-6- общий вид; 2, 7-11 - эдеагус; 3 фаллобаза; 4 - женские гениталии; 1, 4-6 - паратипы, самки; 2-3, 7-8 - паратипы, самцы; 8-11 - голотипы, самцы. Масштабная линейка: 5 мм. 
medially above by about 2.6 times their radius). Ultimate maxillary palpomere small, elongate, slightly widening distally, convex at apex. Antennae narrow, extending to over two thirds of elytra, from antennomere 3 flattened, but parallel-sided; antennomere 3 about 1.5 times longer than antennomere 2 and 2.5 times shorter than antennomere 4; antennomeres 3-11 with short erect pubescence and several longer distal bristles.

Pronotum transverse, trapezoidal, 1.6 times wider than long, with rounded anterior and prominent rounded posterior angles; posterior margin bisinuate. Scutellum elongate, nearly parallel-sided, slightly emarginate at apex.

Elytra long, 3.3 times as long as wide humerally and 6.5 times longer than pronotum, widest in middle, with four equally developed, except at humerus, primary costae; interstices with double rows of irregular cells. Pubescence uniform, short and dense.

Aedeagus with straight, narrow, slightly widened distally median lobe (Figs 8-10).

Length: $9.7 \mathrm{~mm}$. Width (humerally): $2.5 \mathrm{~mm}$; (at elytral middle): $4.2 \mathrm{~mm}$.

Female. Unknown.

ETYMOLOGY. The name of the new species is derived from Poas, a volcano in Costa Rica, in the upper forest belt of which the unique type specimen was collected.

DIAGNOSIS. E. poasensis sp.n. is similar to E. viridimontis sp.n., distinguishable by the slenderer median lobe of the aedeagus with less widened distal portion (Figs 8-10).

\section{Euplateros guanacastensis Kazantsev sp.n.} Fig. 11

MATERIAL: Holotype, $\mathrm{O}^{7}$, Costa Rica, Guanacaste, Rio San Lorenzo, 1000 m, 5.IV.2003, S. Kazantsev leg. (ICCM).

DESCRIPTION. Male. Black. Labial palps, maxillary palpomeres 1-3, antennomeres 10-11, lateral and anterior margins of pronotum yellow.

Head dorsally with conspicuous triangular impression behind antennal prominence, antennal sockets almost contiguous. Eyes relatively small (separated medially above by about 2.2 times their radius). Ultimate maxillary palpomere relatively small, only slightly longer than wide, almost parallel-sided, convex at apex. Antennae from antennomere 3 flattened, but nearly parallel-sided, extending to two thirds of elytra; antennomere 3 about twice as long as antennomere 2 and nearly 2.5 times shorter than antennomere 4 ; antennomeres 3-11 with short erect pubescence and several long distal bristles.

Pronotum transverse, trapezoidal, 1.6 times wider than long, with rounded anterior and acute prominent posterior angles; anterior margin widely rounded; posterior margin bisinuate. Scutellum elongate, narrowing distally, truncate at apex.

Elytra long, 3 times as long as wide humerally and 6 times longer than pronotum, widest in middle, with four equally developed, except at humerus, primary costae; interstices with double rows of mostly irregular cells. Pubescence uniform, short and dense.

Aedeagus with straight, slender, not widened distally median lobe (Fig. 11).

Length: $8.3 \mathrm{~mm}$. Width (humerally): $2.3 \mathrm{~mm}$; (at elytral middle): $3.5 \mathrm{~mm}$.

Female. Unknown.

ETYMOLOGY. The name of the new species is derived from Guanacaste, a province in Costa Rica, where the unique type specimen was collected.

DIAGNOSIS. E. guanacastensis sp.n., appearing similar to $E$. viridimontis sp.n., differs by the mostly yellow palps and two distal antennomeres, as well as by the slenderer and not widened distally median lobe of the aedeagus (Fig. 11).

\section{Teroplas montiviridis Kazantsev sp.n. Figs 12-14}

MATERIAL: Holotype, $\sigma^{7}$, Costa Rica, Monteverde, 1500-1800 m, 15-20.IV.2003, S. Kazantsev leg. (ICCM); paratypes: $\sigma^{7}$ and 2 +9 , same label (ICCM); $0^{7}$, C[osta] R[ica], Puntarenas, Monteverde, 26.V-3.VI.1984, E. Riley, D. Rider \& D. LeDoux (LSAM).

DESCRIPTION. Male. Black. Pronotal lateral and anterior margins and shoulders ochre.

Head dorsally with noticeable roundish impression behind antennal prominence, antennal sockets almost contiguous. Eyes large (separated medially above by their radius). Ultimate maxillary palpomere slightly longer than wide, widest at apex. Antennae from antennomere 3 conspicuously flattened, but almost parallel-sided, extending to three fourths of elytra; antennomere 3 thrice as long as antennomere 2 and 1.2 times shorter than antennomere 4 (Fig. 12); antennomeres 3-11 with short erect pubescence and relatively short distal bristles.

Pronotum transverse, 1.4 times wider than long, with rounded anterior margin and laterally produced acute posterior angles (Fig. 12). Scutellum square, triangularly emarginate at apex.

Elytra long (3.75 times as long as wide humerally), 6.7 times longer than pronotum, widest in posterior two thirds, with four equally developed primary and almost similarly developed secondary costae; interstices with transverse even cells. Pubescence uniform, short and relatively dense.

Aedeagus symmetric, with robust parameres, narrow, ventrally hooked laterophyses and long sclerotized dorsal hook of inner sack of the median lobe (Figs 13-14).

Female. Similar to male, but eyes considerably smaller, antennae somewhat shorter and elytra less conspicuously widened in posterior two thirds elytra.

Length: $8.3-8.8 \mathrm{~mm}$. Width (humerally): $1.8-2.0 \mathrm{~mm}$.

ETYMOLOGY. The name of the new species is derived from the Latin for Monteverde, the area in Puntarenas, Costa Rica, where the type series was collected.

DIAGNOSIS. T. montiviridis sp.n. appears to be related to T. talamancaensis Kazantsev, 2005, easily distinguishable by the shape of pronotum, with much longer posterior angles (Fig. 12), as well as by the more robust parameres and differently shaped laterophyses of the aedeagus (Figs 13-14).

\section{Teroplas tishechkini Kazantsev sp.n. Figs 15-17}

MATERIAL: Holotype, $\sigma^{7}$, Ecuador, Orellana, Yasuni Reserve Stn, 11-26.VII.2008, A. Tishichkin leg. (ICCM); paratypes: $2 \sigma^{7} \sigma^{\top}$, same label; $2 \sigma^{\top} \sigma^{\Upsilon}$, Ecuador, Orellana, Tipuni Biol. Stn, 28.VII3.VIII.2008, A. Tishichkin leg. (ICCM).

DESCRIPTION. Male. Black. Antennomere 11, pronotal lateral margins, elytral margins from humeri to elytral half, trochanters and femurs basally ochre.

Head dorsally with transverse impression behind antennal prominence, antennal sockets separated by minute lamina. Eyes small (separated medially above by ca. 3 times their radius). Ultimate maxillary palpomere slightly longer than wide, widest at apex. Antennae from antennomere 3 conspicuously flattened and slightly serrate, extending to three fourths of elytra; antennomere 3 twice as long as antennomere 2 and 1.7 times shorter than antennomere 4 (Fig. 15); antennomeres 3-11 with short sub-erect pubescence and long isolated, mostly distal, bristles.

Pronotum transverse, 1.6 times wider than long, with rounded anterior and latero-posterioly produced acute poste- 

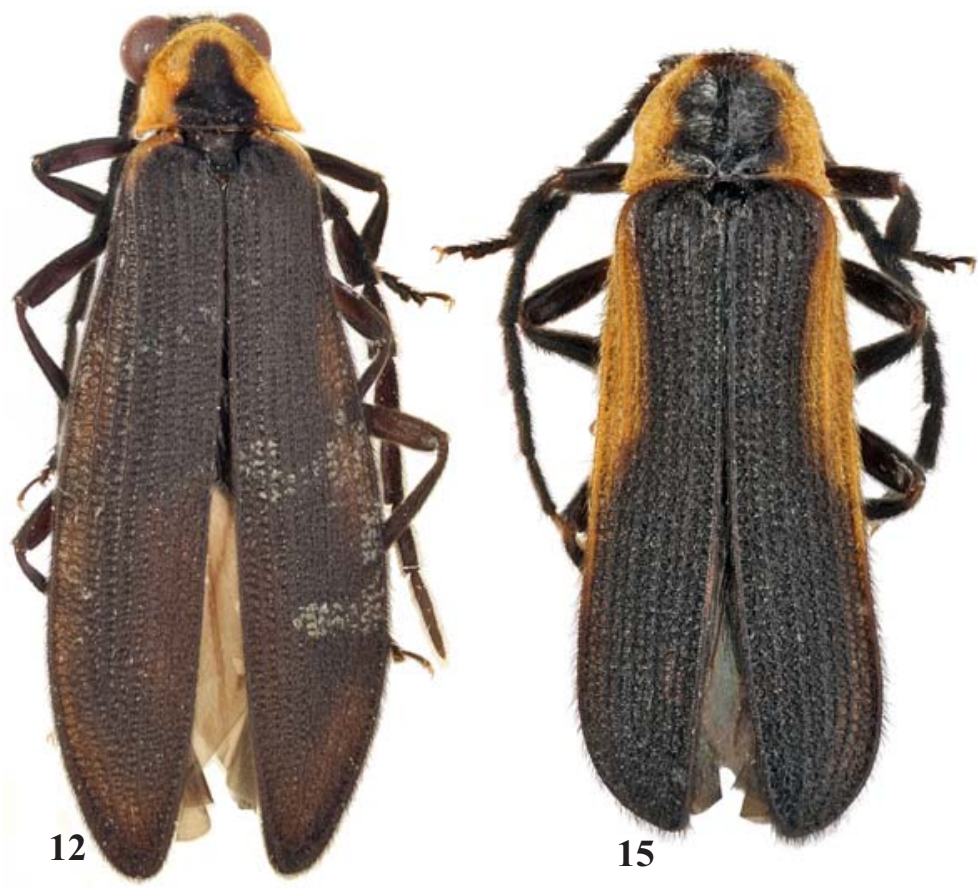

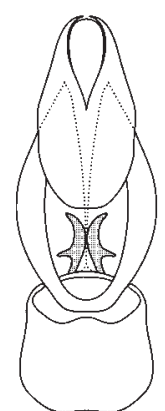

13
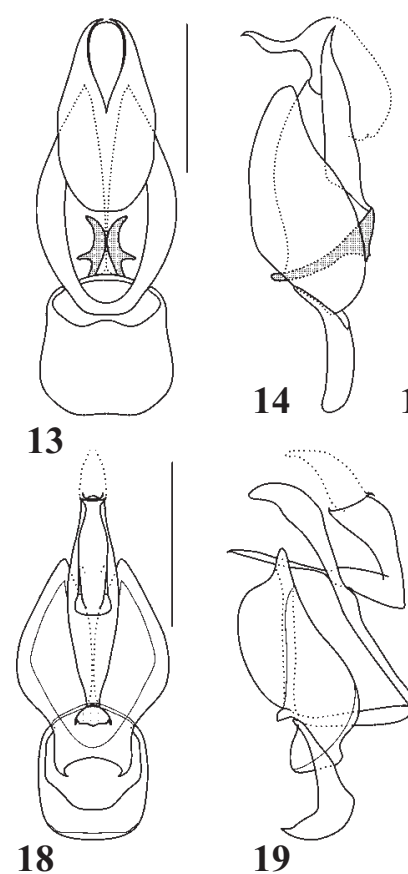

16
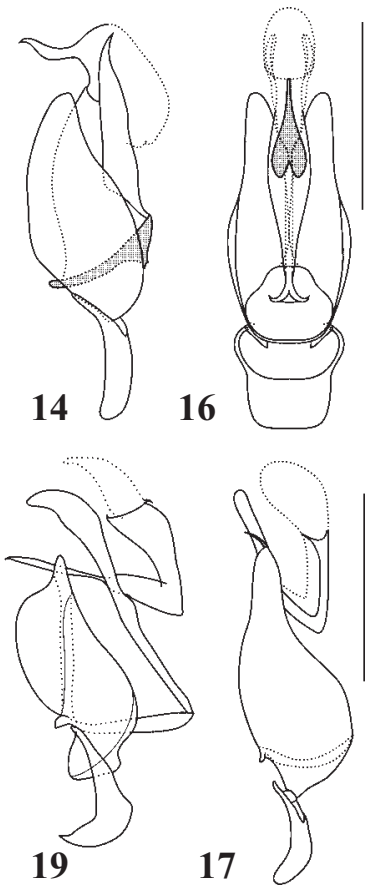

Figs 12-19. General view and aedeagi of Teroplas spp., holotypes males: $12-14-$ T. montiviridis sp.n. $(1=8.8$ mm); $15-17-T$. tishechkini sp.n. $(1=6.7 \mathrm{~mm})$; $18-19-$ T. petrovi sp.n.; $12,15-$ general view; $13-14,16-19-$ aedeagus. Scale bar: 5 mm.

Рис. 12-19. Общий вид и эдеагусы Teroplas spp., голотипы, самцы: $12-14-$ T. montiviridis sp.n. $(1=8.8$ mm); $15-17-$ T. tishechkini sp.n. $(1=6.7$ mm); 18-19 - T. petrovi sp.n.; 12, 15 - общий вид; 13-14, 16-19 — эдеагус. Масштабная линейка: 5 мм.

rior angles (Fig. 15). Scutellum square, inconspicuously emarginate at apex.

Elytra long (3.1 times as long as wide humerally), 4.6 times longer than pronotum, almost parallel-sided, with primary costa 4 conspicuously elevated in proximal half; otherwise primary costae equally developed; secondary costae weaker; interstices with roundish or elongate even cells. Pubescence uniform, short and relatively dense.

Aedeagus with distally constricted parameres and by the curved apex of the median lobe (Figs 16-17).

Length: $6.6-6.8 \mathrm{~mm}$. Width (humerally): $1.8-2.0 \mathrm{~mm}$.

Female. Unknown.

ETYMOLOGY. The new species is named after Dr. A. Tishechkin, who collected the type series.

DIAGNOSIS. T. tishechkini sp.n. may be placed near $T$. montiviridis sp.n., but is easily distinguishable by the more parallel-sided elytra with ochre humeral stripe (Fig. 15), as well as by the distally constricted parameres and by the curved apex of the median lobe of the aedeagus (Figs 16-17).

VARIATION. In one of the paratypes two distal antennomeres are yellow; in two paratypes, from each of the two type localities, the black coloration of elytra is interrupted by an ochre band in the middle.

\section{Teroplas petrovi Kazantsev sp.n.}

Figs 18-19

MATERIAL: Holotype, $\sigma^{7}$, Peru, Loreto, R. Amazon, 68 km SW Iquitos (to Nauta), R. Itaya, $4^{\circ} 11^{\prime}$ S $73^{\circ} 26^{\prime} \mathrm{W}, 120$ m, 1-9.II.2007, A. Petrov leg. (ICCM).

DESCRIPTION. Male. Black. Antennomere 2 and antennomere 3 internally, pronotal lateral margins, elytral margins from humeri to elytral two thirds and stripe at elytral two thirds ochre.

Head dorsally with roundish impression behind antennal prominence, antennal sockets separated by minute lamina.
Eyes small (separated medially above by ca. 2 times their radius). Ultimate maxillary palpomere slightly longer than wide, widest at apex. Antennae from antennomere 3 conspicuously flattened and slightly serrate, extending to three fourths of elytra; antennomere 31.4 times longer than antennomere 2 and 2 times shorter than antennomere 4; antennomeres 3-11 with short sub-erect pubescence and longer isolated, mostly distal, bristles.

Pronotum transverse, 1.3 times wider than long, with rounded anterior and small latero-posterioly produced acute posterior angles. Scutellum square, inconspicuously emarginate at apex.

Elytra long, 2.9 times as long as wide humerally and 4.5 times longer than pronotum, almost parallel-sided, with primary costa 4 conspicuously elevated in proximal half; otherwise primary costae equally developed; secondary costae weaker; interstices with roundish cells. Pubescence uniform, short and relatively dense.

Aedeagus with relatively short and broad parameres and broad phallobase (Figs 18-19).

Length: $6.4 \mathrm{~mm}$. Width (humerally): $1.7 \mathrm{~mm}$.

Female. Unknown.

ETYMOLOGY. The new species is named after Dr. A. Petrov, who collected the type specimen.

DIAGNOSIS. T. petrovi sp.n. is similar to T. tishechkini sp.n. and apparently closely related to it, distinguishable by the black antennal apices and legs, as well as by the shorter, broader and more roundish parameres and broad phallobase of the aedeagus (Figs 18-19).

REMARKS. New species of Teroplas Gorham, 1884 from Ecuador and Peru represent a considerable extension of distribution of the genus, which previously was known only in Mesoamerica [Kazantsev, 2006b]. At the same time it should noted that $T$. tishechkini sp.n. and $T$. petrovi sp.n. occupy a somewhat intermediate position between Teroplas 

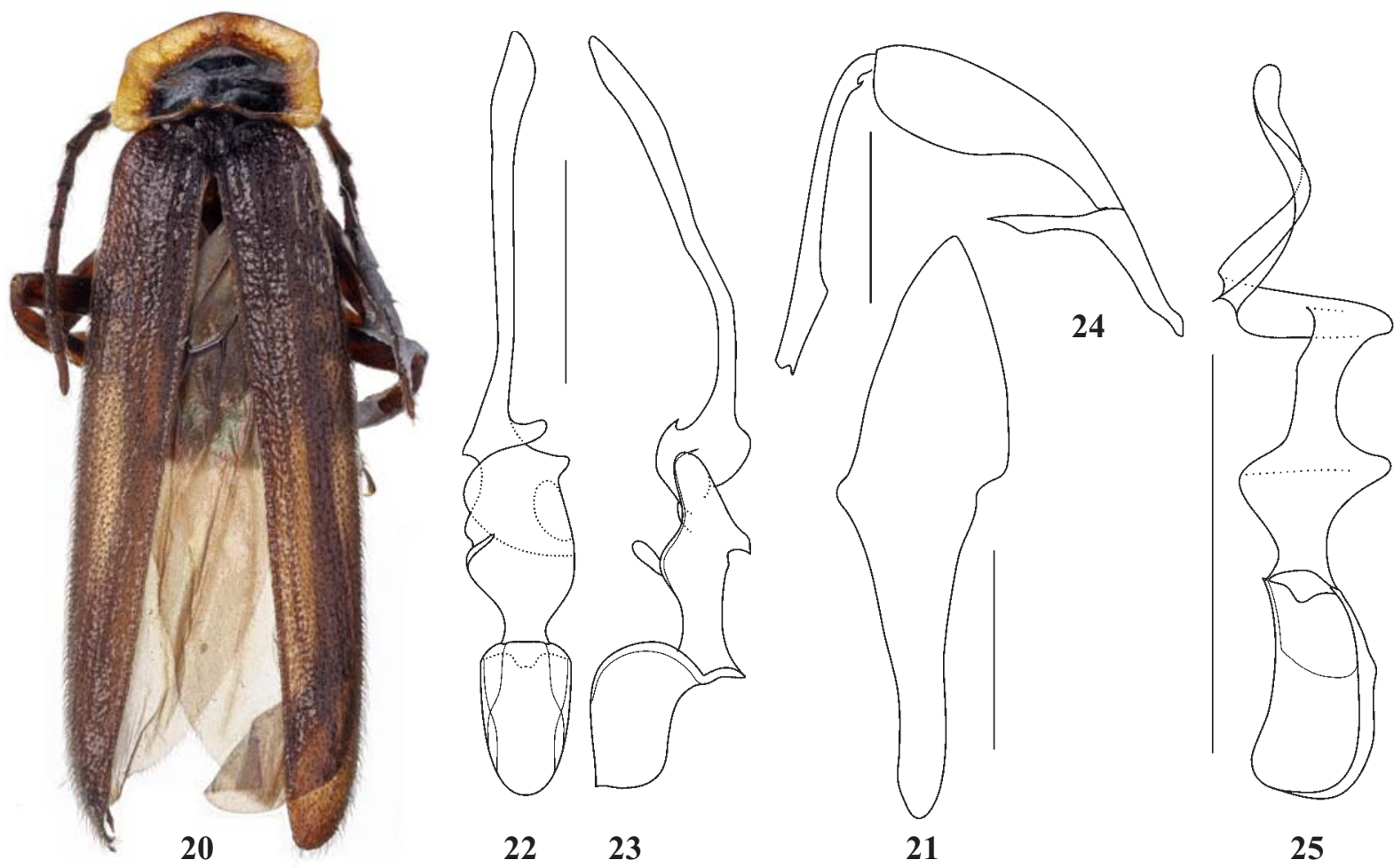

Figs 20-25. General view and aedeagi of Paraplateros and Cavoplateros spp., holotypes males: 20-23 - P. metagalpaensis sp.n.; 24-25 C. victoriensis sp.n.; 20 - general view $(1=7.0 \mathrm{~mm}) ; 21$ — terminal ventrite; 24 — hind leg; $22-23$, 25 — aedeagus. Scale bar: 5 mm.

Рис. 20-25. Общий вид и эдеагусы Paraplateros and Cavoplateros spp., голотипы, самцы: 20-23 - P. metagalpaensis sp.n.; $24-$ 25 - C. victoriensis sp.n.; 20 - общий вид $(1=7.0 \mathrm{~mm}) ; 21$ - вершинный вентрит; 24 - задняя нога; $22-23,25-$ эдеагус. Масштабная линейка: 5 мм.

and Microlycus Pic, 1922, possessing almost parallel-sided elytra with proximally elevated fourth costa (Fig. 15), more characteristic of Microlycus, on the one hand, and long and not pointed distally parameres of the aedeagus (Figs 16-19), characteristic of Teroplas, on the other. Details of female genitalia [discussed in Kazantsev, 2005], which might have brought greater clarity to the systematic position of these two species, are unavailable, as specimens of this gender have not been discovered yet.

\section{Paraplateros metagalpaensis Kazantsev sp.n.}

Figs 20-23

MATERIAL: Holotype, $0^{7}$, Nicaragua, Metagalpa, Rt 8 , 10.VIII.1985 (ICCM).

DESCRIPTION. Male. Black. Lateral and anterior margins of pronotum ochre.

Head dorsally with noticeable impression behind antennal prominence, antennal sockets separated by relatively prominent lamina. Eyes small (separated medially above by about 4 times their radius). Ultimate maxillary palpomere small, elongate, widest at apex. Antennae from antennomere 3 flattened, serrate, not attaining middle of elytra; antennomere 3 about twice as long as antennomere 2 and 1.6 times shorter than antennomere 4; antennomeres 3-11 with short semi-erect pubescence and isolated longer bristles on external surface.

Pronotum almost square, only 1.1 times wider than long, with straight sides, noticeable anterior and small acute posterior angles; shining, with raised lateral and anterior margins (Fig. 20). Scutellum square, truncate at apex.
Elytra long (3.6 times as long as wide humerally), parallel-sided, with four noticeable primary costae; interstices coarsely punctured (Fig. 20). Pubescence uniform, short, relatively scarce. Terminal sternite asymmetric (Fig. 21).

Aedeagus with slender and slightly bent in lateral view median lobe (Figs 22-23).

Length: $7.0 \mathrm{~mm}$. Width (humerally): $1.6 \mathrm{~mm}$.

Female. Unknown.

ETYMOLOGY. The name of the new species is derived from Metagalpa, the area in Nicaragua, where the unique type specimen was collected.

DIAGNOSIS. P. metagalpaensis sp.n. is similar to $P$. parallelus (Gorham, 1880), distinguishable by the black elytral shoulders and legs, as well as by the much slenderer median lobe of the aedeagus (Figs 22-23).

REMARKS. Paraplateros Zaragoza, 1999, stat.n., proposed as a subgenus of Plateros [Zaragoza, 1999], is readily differentiated from it by the non-reticulated elytra, with the elytral interstices, instead of bearing a row/rows of cells, just densely punctured (Fig. 20), and asymmetric terminal sternite (Fig. 21), and is hereby raised to the genus level, as the importance of the above-mentioned characters is clearly of generic value in this lineage of net-winged beetles.

\section{Cavoplateros victoriensis Kazantsev sp.n.} Figs 24-25

MATERIAL: Holotype, $0^{7}$, Mexico, $25 \mathrm{~km}$ SW Col. Victoria, Madrono, 1200 m, oak-palm forest, 3.IV.2002, D. Kasparyan leg. (ICCM). 


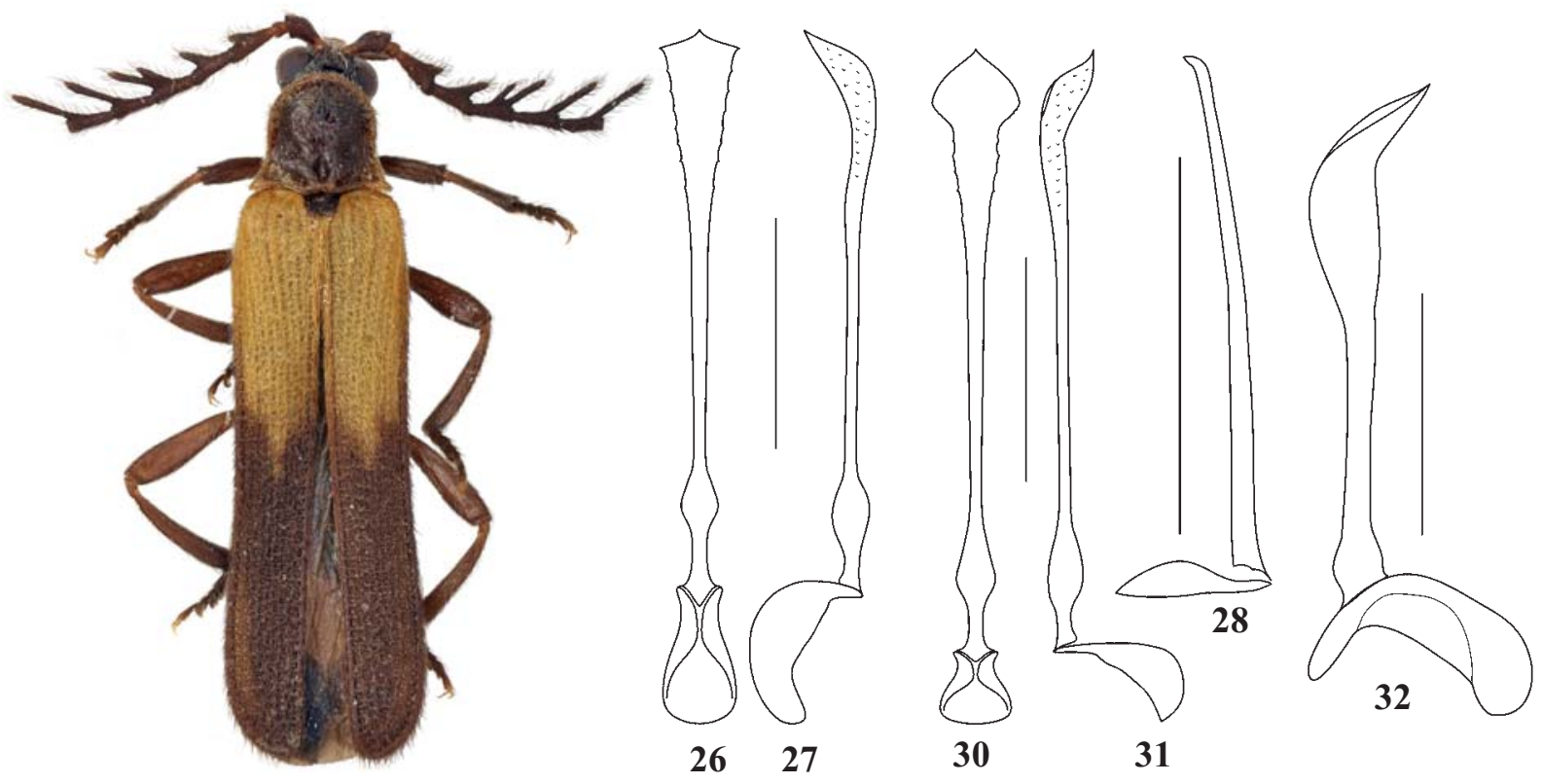

29

Figs 26-32. General view and aedeagi of Falsotrichalus spp., holotypes males: 26-27 - F. bukitensis sp.n.; $28-F$. haedus sp.n.; 2931 - F. luchti sp.n.; $32-F$. slametensis sp.n.; 29 - general view $(1=5.3 \mathrm{~mm})$; 26-28, 30-32 — aedeagus. Scale bar: 5 mm.

Рис. 26-32. Общий вид и эдеагусы Falsotrichalus spp., голотипы, самцы: 26-27 — F. bukitensis sp.n.; 28 - F. haedus sp.n.; 2931 - F. luchti sp.n.; 32 - F. slametensis sp.n.; 29 - общий вид (1=5.3 мм); 26-28, 30-32 - эдеагус. Масштабная линейка: 5 мм.

DESCRIPTION. Male. Dark brown. Sides of pronotum and elytral shoulders ochre.

Head dorsally with small roundish impression behind antennal prominence, antennal sockets almost contiguous. Eyes relatively large (separated medially above by about 1.2 times their radius). Ultimate maxillary palpomere relatively small, elongate, almost parallel-sided, obliquely cut at apex. Antennae from antennomere 3 flattened, nearly parallelsided, extending to middle of elytra; antennomere 3 about twice as long as antennomere 2 and 1.3 times shorter than antennomere 4; antennomeres 3-11 with short semi-erect pubescence and numerous longer bristles.

Pronotum transverse, 1.3 times wider than long, with straight sides, noticeable anterior and acute prominent posterior angles, anterior margin triangularly produced forward. Scutellum square, truncate at apex.

Elytra long (3.7 times as long as wide humerally), parallel-sided, with four equally developed primary costae; interstices with double rows of small round cells. Pubescence uniform, relatively dense and erect. Metatrochanter with prominent acute distal appendage received by metatibial groove (Fig. 24).

Aedeagus with spirally bent distal portion of median lobe (Fig. 25).

Length: $5.2 \mathrm{~mm}$. Width (humerally): $1.2 \mathrm{~mm}$.

Female. Unknown.

ETYMOLOGY. The name of the new species is derived from Col. Victoria, the area in Mexico, where the unique type specimen was collected.

DIAGNOSIS. C. victoriensis sp.n. is habitually similar to $C$. dentatus Pic, 1922, but is easily distinguishable by the broader pronotum, as well as by the absence of an apical hook of median lobe of the aedeagus (Fig. 25). Also, unlike in the other species of Cavoplateros Pic, 1913, in C. victoriensis sp.n. it is not the metafemur, but the metatrochanter that bears a prominent acute distal appendage received by a groove in the metatibia (Fig. 24).

\section{Falsotrichalus bukitensis Kazantsev sp.n.} Figs 26-27

MATERIAL: Holotype, $\mathrm{O}^{7}$, S Sumatra, Lampung, Bukit Barisan Selatan N.P., $5 \mathrm{~km}$ SW Liwa, 5 ${ }^{\circ}$ 'S $104^{\circ} 4^{\prime} \mathrm{E}, 600 \mathrm{~m}$, 717.II.2000, D. Hauck leg. (ICCM); paratype, O ${ }^{\top}$, [S Sumatra], Oosthaven, III.1950, C.v. Nidek (ZMAU).

DESCRIPTION. Male. Black. Pronotum, except narrow margins, and elytra, except narrow margins and longitudinal patches at basal fourth, dark brown; pronotal and elytral margins and longitudinal patches at elytral basal fourth light brown.

Head dorsally with conspicuous roundish impression behind antennal prominence, antennal sockets separated by minute lamina. Eyes moderately large (separated medially above by about 1.1 times their radius). Ultimate maxillary palpomere relatively small, narrow, elongate, almost parallel-sided, oblique and convex at apex. Antennae from antennomere 4 flabellate, extending to elytral two thirds; antennomere 3 about 4 times longer than antennomere 2 and subequal in length to antennomere 4; antennomeres 3-11 with long erect bristling pubescence.

Pronotum transverse, 1.3 times wider than long, with noticeable anterior and acute posterior angles, anterior margin convex; posterior margin bisinuate. Scutellum square, parallel-sided, slightly emarginate at apex.

Elytra long (3.5 times as long as wide humerally), conspicuously narrowed distally, with four well developed primary costae; interstices with double rows of small cells. Pubescence double, short, dense and decumbent, partially hiding elytral reticulation, and longer and sparser scattered bristling hairs.

Aedeagus with straight widened distally median lobe, with laterally dentate apex (Figs 26-27). 
Length: $5.4-5.9 \mathrm{~mm}$. Width (humerally): $1.3-1.4 \mathrm{~mm}$. Female. Unknown.

ETYMOLOGY. The name of the new species is derived from the Indonesian for "national park", alluding to the place where one the type specimens was collected.

DIAGNOSIS. F. bukitensis sp.n. is apparently close to $F$. luchti sp.n., distinguishable by the bicoloured elytra, with ochre proximal half, as well as by the gradually widened median lobe of the aedeagus (Figs 26-27).

VARIATION. In the paratype the elytra are uniformly dark brown.

\section{Falsotrichalus haedus Kazantsev sp.n.} Fig. 28

MATERIAL: Holotype, $0^{\top}$, E Malaysia, Sabah, Poring Hot Springs, 500-600 m, 8-15.IVI.2002, S. Kurbatov \& S. Zimina leg. (ICCM).

DESCRIPTION. Male. Dark brown. Pronotal lateral margins posteriorly, elytra in basal fourth and elytral margins in basal half, trochanters bases of femurs ochre.

Head dorsally with two small longitudinal impressions behind antennal prominence, antennal sockets separated by narrow lamina. Eyes small (separated medially above by about 2.8 times their radius). Ultimate maxillary palpomere small, narrow, elongate, glabrous and pointed at apex. Antennae from antennomere 3 serrate, extending to elytral half; antennomere 3 about 2.3 times longer than antennomere 2 and 1.1 times shorter than antennomere 4; antennomeres 3 11 with long erect bristling pubescence.

Pronotum transverse, 1.2 times wider than long, with straight sides, noticeable anterior and small acute posterior angles, anterior margin convex; posterior margin slightly bisinuate. Scutellum transverse, parallel-sided, very slightly emarginate at apex.

Elytra long (3.2 times as long as wide humerally), conspicuously narrowed in posterior half, with four well developed primary costae; interstices with double rows of irregular cells. Pubescence uniform, relatively short, dense and sub-erect.

Aedeagus with straight simple median lobe (Fig. 28).

Length: $3.5 \mathrm{~mm}$. Width (humerally): $0.8 \mathrm{~mm}$.

Female. Unknown.

ETYMOLOGY. The name of the new species is derived from the Latin for "kid", alluding to the small size of the unique type specimen.

DIAGNOSIS. F. haedus sp.n. differs from all male congenerics by the small eyes, simple, not flabellate, antennae and straight simple median lobe of the aedeagus (Fig. 28).

\section{Falsotrichalus luchti Kazantsev sp.n.} Figs 29-31

MATERIAL: Holotype, $0^{7}$, Java, K.O. Blavan, Idjen Plateau, 900-1500 m, XII.[19]38, H. Lucht leg. (ZMAU); paratype, ㅇ, same label (ICCM)

DESCRIPTION. Male. Dark brown. Narrow pronotal margins light brown; prpoximal half of elytra ochre.

Head dorsally with two small longitudinal impressions behind antennal prominence, antennal sockets separated by minute lamina. Eyes relatively large (separated medially above by about 2 times their radius). Ultimate maxillary palpomere relatively small, narrow, elongate, almost parallel-sided, oblique and convex at apex. Antennae from antennomere 3 flabellate; antennomere 3 about 2.8 times longer than antennomere 2 and 1.1 times longer than antennomere 4 ; antennomeres 3-11 with long erect bristling pubescence (Fig. 29).

Pronotum almost square, only 1.1 times wider than long, with long acute posterior angles and anteriorly produced rounded anterior margin; posterior margin bisinuate (Fig. 29). Scutellum square, almost parallel-sided, slightly emarginate at apex.

Elytra long (3.5 times as long as wide humerally), slightly narrowed distally, with four well developed primary costae; interstices with double rows of small cells. Pubescence double, short, dense and decumbent, partially hiding elytral reticulation, and longer and sparser scattered bristling hairs.

Aedeagus with straight, abruptly widened distally median lobe and laterally dentate apex (Figs 30-31).

Female. Similar to male, but more robust, eyes somewhat smaller, antennomeres 3-10 only serrate. Genitalia with separated robust sclerotised coxites and valvifers; accessory gland single, large, pear-shaped; seminal duct short, spermatheca relatively short, oval.

Length: $5.3-7.1 \mathrm{~mm}$. Width (humerally): $1.2-1.6 \mathrm{~mm}$.

ETYMOLOGY. The new species is named after Mr. H. Lucht, who collected the type series.

DIAGNOSIS. F. luchti sp.n. resembles $F$. gracilicornis Pic, 1921, illustrated in a recent paper [Kazantsev, 2005a], but may be distinguished by the straight median lobe of the aedeagus, with numerous minute apical teeth (Figs 30-31). Unlike in F. lankaensis Kazantsev, 2006, the other Falsotrichalus Pic, 1921 species where a female is known, the coxites and valvifers of female genitalia of $F$. luchti sp.n. are not fused, and in this respect it resembles Plateros. Although the accessory gland of the internal female genitalia of the new species is single, whereas in Plateros it is a paired organ [e.g., Bocáková, 2001], it seems that to clarify the taxonomic status of this genus, which was revalidated from synonymy with Plateros [Kazantsev, 2005b], additional studies are needed.

VARIATION. Antennomere 5 of both antennae of the holotype of F. luchti sp.n. has two flabellae (Fig. 29), which appears to be due to teratology.

\section{Falsotrichalus slametensis Kazantsev sp.n.} Fig. 32

MATERIAL: C Java, Gunung Slamet, S slopes, 21-25.II.1996, V. Sinyaev leg. (ICCM).

DESCRIPTION. Male. Black. Pronotum, except narrow margins, and elytra, except basal fourth and lateral margins at basal two thirds, dark brown; pronotal margins, elytral basal fourth and lateral margins at basal two thirds ochre.

Head dorsally with two roundish impressions behind antennal prominence, antennal sockets separated by minute lamina. Eyes small (separated medially above by about 2.3 times their radius). Ultimate maxillary palpomere relatively small, narrow, elongate, almost parallel-sided, oblique and convex at apex. Antennae from antennomere 4 flabellate, extending to elytral two thirds; antennomere 3 about 2.5 times longer than antennomere 2 and subequal in length to antennomere 4; antennomeres 3-11 with long erect bristling pubescence.

Pronotum almost square, only 1.1 times wider than long, with noticeable anterior and acute posterior angles, anterior margin convex; posterior margin bisinuate. Scutellum transverse, parallel-sided, slightly emarginate at apex.

Elytra long (3.4 times as long as wide humerally), slightly narrowed distally, with four well developed primary costae; interstices with double rows of small cells. Pubescence double, short, dense and decumbent, partially hiding elytral reticulation, and longer and sparser scattered bristling hairs.

Aedeagus with narrow proximally and conspicuously flattened and widened and slightly curved distally median lobe (Fig. 32).

Length: $5.9 \mathrm{~mm}$. Width (humerally): $1.5 \mathrm{~mm}$.

Female. Unknown. 


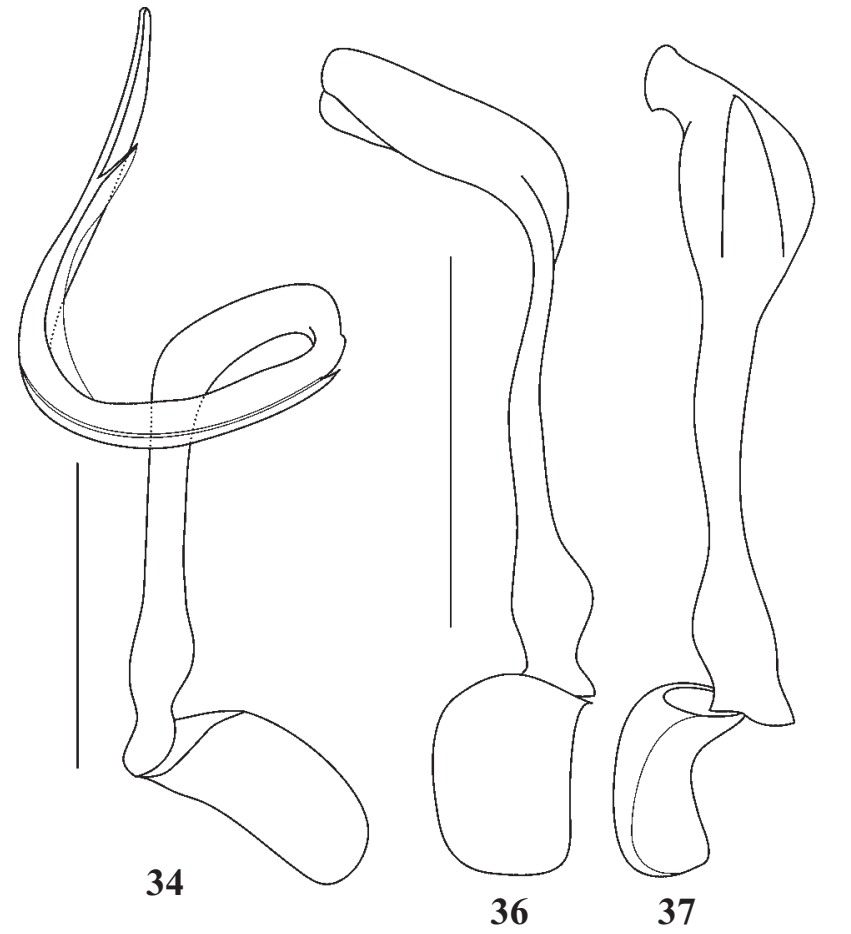

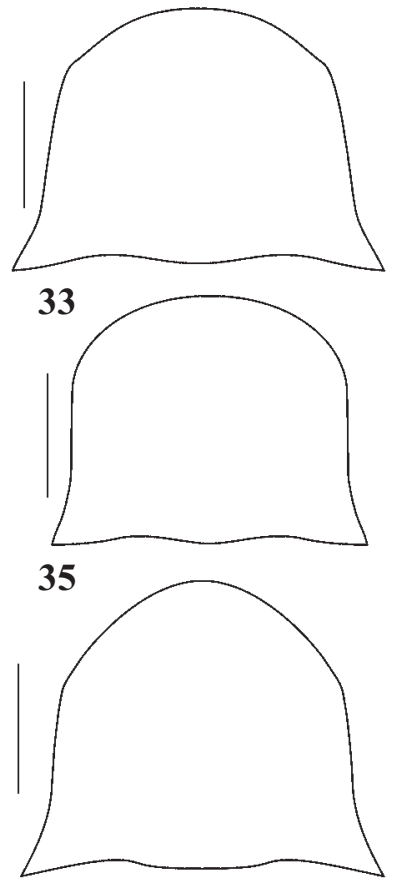

38

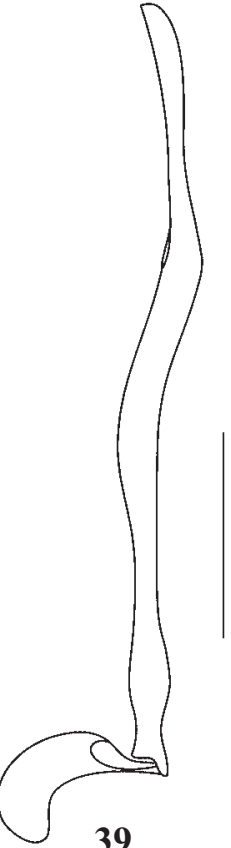

39

40
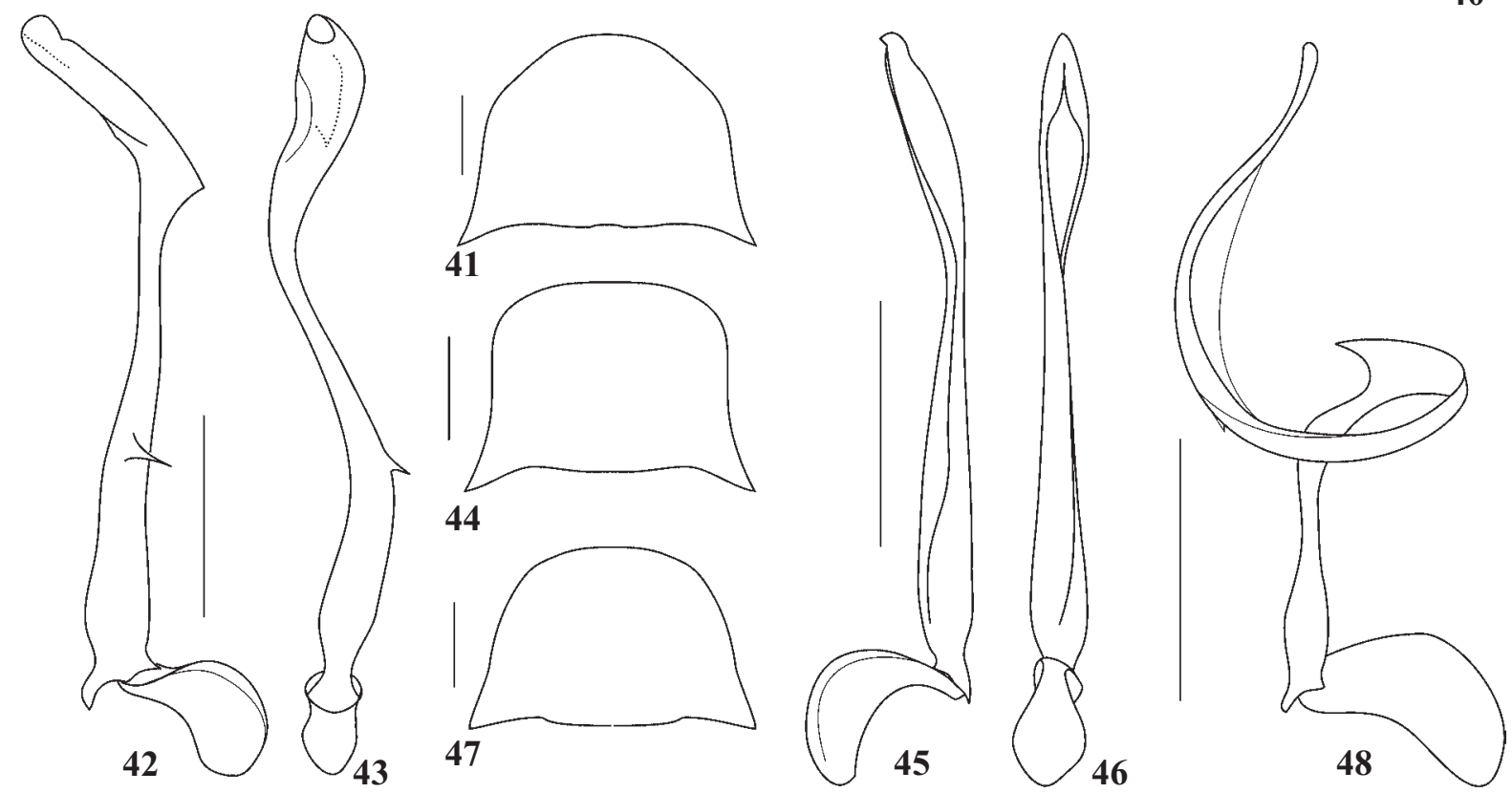

Figs 33-48. Details of Plateros spp., holotypes males: 33-34 - P. nantouensis sp.n.; 35-37 - P. obrienorum sp.n.; 38-40 - P. bengalensis sp.n.; 41-43-P. burmensis sp.n.; 44-46-P. karnaliensis sp.n.; 47-48 - P. myanmarensis sp.n.; 33, 35, 38, 41, 44, 47 pronotum; 34, 36-37, 38-40, 42-43, 45-46, 48 - aedeagus. Scale bar: $5 \mathrm{~mm}$.

Рис. 33-48. Детали строения Plateros spр., голотипы, самцы: 33-34 - P. nantouensis sp.n.; 35-37 — P. obrienorum sp.n.; 38-40 P. bengalensis sp.n.; 41-43 — P. burmensis sp.n.; 44-46 - P. karnaliensis sp.n.; 47-48 — P. myanmarensis sp.n.; 33, 35, 38, 41, 44, 47 — переднеспинка; 34, 36-37, 38-40, 42-43, 45-46, 48 - эдеагус. Масштабная линейка: 5 мм.

ETYMOLOGY. The name of the new species is derived from Gunung Slamet, an area in central Java, where the unique type specimen was collected.

DIAGNOSIS. F . slametensis sp.n. seems to be related to F. gracilicornis, distinguishable by the distally black, without testaceous margins, elytra, as well as by the distally less curved median lobe of the aedeagus (Fig. 32).

\section{Plateros nantouensis Kazantsev sp.n.} Figs 33-34

MATERIAL: Holotype, $\sigma^{7}$, Taiwan, Nantou Co., Huisun For. Rec. Area, 919 m, 20-21.V.1999, blacklight trap, C.W. \& L.B. O’Brien leg. (ICCM).

DESCRIPTION. Male. Dark brown. Pronotum, except at disk, and elytra reddish testaceous. 
Head dorsally with conspicuous roundish impression behind antennal prominence, antennal sockets separated by minute lamina. Eyes moderately large (separated medially above by about their radius). Ultimate maxillary palpomere relatively small, only slightly longer than wide, widest at middle, convex at apex. Antennae from antennomere 3 flattened, strongly serrate, extending to elytral two thirds; antennomere 3 about 2.2 longer than antennomere 2 and 1.1 times shorter than antennomere 4; antennomeres 3-11 with long curly erect pubescence.

Pronotum transverse, trapezoidal, 1.6 times wider than long, with noticeable anterior and acute prominent posterior angles, anterior margin almost triangularly produced forward (Fig. 33). Scutellum square, truncate at apex.

Elytra long (3.1 times as long as wide humerally), parallel-sided, only slightly widened behind shoulders, with four equally developed primary costae; interstices with double rows of square cells. Pubescence uniform, relatively dense, short and decumbent.

Aedeagus with spiral and narrowed distally median lobe; preapical tooth absent (Fig. 34).

Length: $6.6 \mathrm{~mm}$. Width (humerally): $1.8 \mathrm{~mm}$.

Female. Unknown.

ETYMOLOGY. The name of the new species is derived from the county in central Taiwan, where the unique type specimen was collected.

DIAGNOSIS. $P$. nantouensis sp.n. is similar to $P$. laticeps (Pic, 1921), also characterized by the spiral median lobe of the aedeagus, but differs by the reddish elytra, as well as by the absence of a preapical tooth and narrower distal portion of the median lobe of the aedeagus (Fig. 34).

\section{Plateros obrienorum Kazantsev sp.n.} Figs 35-37

MATERIAL: Holotype, $0^{7}$, Taiwan, Nantou Co., Huisun For. Rec. Area, 919 m, 20-21.V.1999, blacklight trap, C.W. \& L.B. O'Brien leg. (ICCM).

DESCRIPTION. Male. Black. Narrow pronotal margins, trochanters and femurs at base testaceous.

Head dorsally with shallow roundish impression behind antennal prominence, antennal sockets separated by minute lamina. Eyes relatively small (separated medially above by about 2 times their radius). Ultimate maxillary palpomere small, elongate, parallel-sided, convex at apex. Antennae from antennomere 3 flattened, nearly parallel-sided, extending to two thirds of elytra; antennomere 3 about twice as long as antennomere 2 and 1.3 times shorter than antennomere 4 ; antennomeres 3-11 with short erect pubescence.

Pronotum transverse, with almost straight sides, 1.4 times wider than long, with rounded anterior and acute prominent posterior angles, anterior margin evenly rounded (Fig. 35). Scutellum elongate, nearly parallel-sided, slightly emarginate at apex.

Elytra long (3.5 times as long as wide humerally), parallel-sided, with four equally developed primary costae; interstices with double rows of small subquadrate cells. Pubescence uniform, sub-erect, short and relatively scarce.

Aedeagus with widened and inclined distally median lobe (Figs 36-37)

Length: $5.8 \mathrm{~mm}$. Width (humerally): $1.4 \mathrm{~mm}$.

Female. Unknown.

ETYMOLOGY. The new species is named after Dr. C.W. O'Brien and his wife, L.B. O'Brien, who collected the type specimen.

DIAGNOSIS. $P$. obrienorum $\mathbf{s p . n . ~ i s ~ p o s s i b l y ~ r e l a t e d ~ t o ~} P$. maculatithorax (Pic, 1921), having somewhat similar male genitalia, but is easily distinguishable by the black elytra and less curved distally median lobe of the aedeagus (Figs 36-37).

\section{Plateros bengalensis Kazantsev sp.n. Figs 38-40}

MATERIAL: Holotype, $\sigma^{\top}$, India, West Bengalen, Distr. Darjeeling, Kurseong, Golma Forest, 1330 m, 22.VII.1987, H. Dangal leg. (NKME)

DESCRIPTION. Male. Black. Pronotum, scutellum and elytra dull testaceous.

Head dorsally with two conspicuous elongate impressions behind antennal prominence, antennal sockets separate by minute lamina. Eyes relatively small (separated medially above by about 1.7 times their radius). Ultimate maxillary palpomere small, elongate, slightly widening distally, convex at apex. Antennae from antennomere 3 flabellate, flabellae in antennomeres 3-10 conspicuously longer than antennomeres; antennomere 3 about 3.6 times longer than antennomere 2 and 1.2 times longer than antennomere 4; antennomeres 3-11 with long erect pubescence.

Pronotum transverse, slightly trapezoidal, 1.3 times wider than long, with rounded anterior and long acute posterior angles (Fig. 38). Scutellum square, slightly emarginate at apex.

Elytra long (3.75 times as long as wide humerally), parallel-sided, with four equally developed primary costae; interstices with double rows of small roundish cells. Pubescence uniform, dense, concealing elytral reticulation.

Aedeagus with straight narrowed distally median lobe (Figs 38-40).

Length: $7.6 \mathrm{~mm}$. Width (humerally): $1.8 \mathrm{~mm}$.

Female. Unknown.

ETYMOLOGY. The name of the new species is derived from the province in northeast India, where the type specimen was collected.

DIAGNOSIS. P. bengalensis sp.n. is somewhat similar to $P$. assamensis (Pic, 1928), easily distinguishable by the uniformly testaceous pronotum and straight median lobe of the aedeagus (Figs 38-40).

\section{Plateros burmensis Kazantsev sp.n.} Figs 41-43

MATERIAL: Holotype, $\sigma^{7}, \mathrm{~N}$ Myanmar (Burma), $65 \mathrm{~km} \mathrm{NW}$ Putao, Zi Var Dam, 1250 m, 18-21.V.1998, S. Murzin leg. (ICCM); paratype, $q$, same label (ICCM).

DESCRIPTION. Male. Black. Pronotum and scutellum orange; elytra bright red.

Head dorsally with small round impression behind antennal prominence, antennal sockets almost contiguous. Eyes small (separated medially above by about 2.2 times their radius). Ultimate maxillary palpomere small, elongate, slightly widening distally, convex at apex. Antennae from antennomere 3 flattened, broad, strongly serrate, extending to middle of elytra; antennomere 3 about twice as long as antennomere 2 and 1.8 times shorter than antennomere 4; antennomeres $3-$ 11 with relatively long decumbent pubescence.

Pronotum transverse, trapezoidal, 1.5 times wider than long, with rounded anterior and long acute posterior angles, anterior margin relatively rounded (Fig. 41). Scutellum square, truncate at apex.

Elytra long (3.2 times as long as wide humerally), flattened, slightly widening behind shoulders, with four equally developed primary costae; interstices with double rows of quadrate cells. Pubescence uniform, dense and short.

Aedeagus slender, with slightly widened distally median lobe, provided with spines in central and preapical portions (Figs 42-43). 
Female. Similar to male, but larger and broader, antennae less serrate.

Length: 7.8-10.2 mm. Width (humerally): $2.0-3.7 \mathrm{~mm}$.

ETYMOLOGY. The name of the new species is derived from the old name of the country, where the type series was collected.

DIAGNOSIS. P. burmensis sp.n., being quite unlike the other Himalayan Plateros due to its bicoloured bright red and orange coloration of the upperside, is also easily distinguishable by the male genital structures (Figs 42-43).

\section{Plateros karnaliensis Kazantsev sp.n.} Figs 44-46

MATERIAL: Holotype, $0^{7}$, Nepal, prov. Karnali, distr. Humla, $500 \mathrm{~m}$ W Simikot, terrace fields, $29^{\circ} 58^{\prime} \mathrm{N} 81^{\circ} 49^{\prime} \mathrm{E}, 16-17 . \mathrm{VI} .2001$, A. Kopetz leg. (NKME); paratypes: $\sigma^{\prime}$, Nepal, prov. Karnali, distr. Humla, $18 \mathrm{~km}$ WNW Simikot, Chumsa Khola (bridge), $30^{\circ} 02^{\prime} \mathrm{N}$ 8139'E, river valley, 2950 m, 20-22.VI.2001, A. Kopetz leg.; O', Nepal, distr. Humla, $18 \mathrm{~km}$ NW Simikot, Brücke am Chumsa Khola $30^{\circ} 02^{\prime} 25^{\prime \prime} \mathrm{N} \mathrm{81}{ }^{\circ} 39^{\prime} 06^{\prime \prime} \mathrm{E}, 2950 \mathrm{~m}, 20-22$.VI.2001, F. Creutzburg leg.; $\sigma^{7}$, Nepal, Karnali/Humla, 18 km WNW Simikot, Chumsa

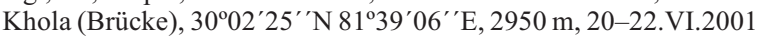
A. Weigel leg.; $\mathrm{O}^{7}$, Nepal, Karnali/Humla, 13 km S Simikot, NE Malikasthan, $29^{\circ} 51^{\prime} \mathrm{N} 81^{\circ} 51^{\prime} \mathrm{E}, 3800-3400 \mathrm{~m}$, coniferous-oak forest, 8.VII.2001, A. Weigel leg.; + , Nepal, Karnali, Jumla to Sisne Himal, 5000 m, 6-20.VI.1995, J. Kolibac leg. (ICCM and NKME).

DESCRIPTION. Male. Black. End elytra testaceous.

Head dorsally with conspicuous roundish impression behind antennal prominence, antennal sockets almost contiguous. Eyes small (separated medially above by about 3 times their radius). Ultimate maxillary palpomere small, elongate, slightly widening distally, convex at apex. Antennae from antennomere 3 flattened, slightly serrate, extending to elytral two thirds; antennomere 3 about thrice as long as antennomere 2 and 1.2 times shorter than antennomere 4; antennomeres 3-11 with short erect pubescence.

Pronotum transverse, trapezoidal, 1.7 times wider than long, almost rectangular, with prominent rounded anterior and acute posterior angles, anterior margin little produced forward (Fig. 44). Scutellum narrowed distally, triangularly emarginate at apex.

Elytra long (3.5 times as long as wide humerally), parallel-sided, with four equally developed primary costae; interstices with double rows of subquadrate cells. Pubescence uniform, relatively dense and decumbent.

Aedeagus with almost straight, slightly widened and bent distally median lobe (Figs 45-46).

Female. Similar to male, but slightly larger and broader. Length: $5.5-8.4 \mathrm{~mm}$. Width (humerally): $1.3-2.1 \mathrm{~mm}$.

ETYMOLOGY. The name of the new species is derived from the province in Nepal, where the type series was collected.

DIAGNOSIS. P. karnaliensis sp.n. is somewhat similar to $P$. planatus Waterhouse, 1879 , easily distinguishable by the uniformly black pronotum and differently shaped aedeagus, with less widened distally median lobe (Figs 45-46).

\section{Plateros myanmarensis Kazantsev sp.n.} Figs 47-48

MATERIAL: Holotype, $\mathrm{O}^{7}$, N Myanmar (Burma), $40 \mathrm{~km} \mathrm{~N}$ Myitkyina, Chanc Kand, 235 m, 23-24.IV.1998, S. Murzin leg. (ICCM).

DESCRIPTION. Male. Black. Pedicel distally brownish.

Head dorsally with two elongate impressions behind antennal prominence, antennal sockets almost contiguous. Eyes small (separated medially above by about 2 times their radius). Ultimate maxillary palpomere relatively small, elongate, parallel-sided, convex at apex. Antennae from antenno- mere 3 flabellate, extending to elytral two thirds; flabellae of antennomeres 4-6 about as long as antennomeres, flabellae of antennomeres 3 and 7-10 shorter than antennomeres; antennomere 3 about thrice as long as antennomere 2 and 1subequal in length to antennomere 4; antennomeres 3-11 with long, erect, curly pubescence.

Pronotum transverse, trapezoidal, 1.5 times wider than long, with rounded anterior and acute posterior angles, anterior margin rounded (Fig. 47). Scutellum square, slightly emarginate at apex.

Elytra long (3.1 times as long as wide humerally), parallel-sided, with four equally developed primary costae; interstices with double rows of quadrate cells. Pubescence double, dense, short and decumbent, and scarcer, longer and suberect.

Aedeagus with spiral narrowed distally median lobe, forming complete regular circle by spiral part, with prominent tooth at base of apical portion (Fig. 48).

Length: $6.8 \mathrm{~mm}$. Width (humerally): $1.8 \mathrm{~mm}$.

Female. Unknown.

ETYMOLOGY. The name of the new species is derived from the country where the type specimen was collected.

DIAGNOSIS. P. myanmarensis sp.n. belongs to the same group as $P$. assamensis (Pic, 1921), easily distinguishable by the uniformly black body and much slenderer median lobe of the aedeagus, with a more prominent preapical spine (Fig. 48).

\section{Plateros putaoensis Kazantsev sp.n. Figs 48-51}

MATERIAL: Holotype, Or, N Myanmar (Burma), $25 \mathrm{~km} \mathrm{E}$ Putao, env. Nam Sa Bon, 800 m, 6-9.V.1998, S. Murzin leg. (ICCM); paratype, + , N Myanmar (Burma), 65 km NW Putao, Zi Var Dam, 1250 m, 18-21.V.1998, S. Murzin leg. (ICCM). brown.

DESCRIPTION. Male. Black. Narrow pronotal margin

Head dorsally with small roundish impression behind antennal prominence, antennal sockets almost contiguous. Eyes large (separated medially above by about their radius). Ultimate maxillary palpomere relatively small, elongate, widening and convex distally. Antennae from antennomere 3 slightly flattened, weakly serrate, extending to elytral two thirds; antennomere 3 about 1.5 times longer than antennomere 2 and 1.7 times shorter than antennomere 4; antennomeres 3-11 with relatively short erect pubescence and longer distal bristles.

Pronotum transverse, 1.2 times wider than long, with almost parallel sides, blunt anterior and acute posterior angles, anterior margin conspicuously produced forward (Fig. 49). Scutellum small, transverse, slightly emarginate at apex.

Elytra long (3.5 times as long as wide humerally), parallel-sided, with four equally developed primary costae; interstices with double rows of small subquadrate cells. Pubescence uniform, short and sub-erect.

Aedeagus with slender, slightly bent distally median lobe, with long needle-shaped tip (Figs 50-51).

Female. Similar to male, but eyes smaller and antennae somewhat shorter.

Length: $6.2-6.7 \mathrm{~mm}$. Width (humerally): $1.35-1.40 \mathrm{~mm}$.

ETYMOLOGY. The name of the new species is derived from the township in northern Myanmar, where the type series was collected.

DIAGNOSIS. P. putaoensis sp.n. is somewhat similar to $P$. planatus Waterhouse, 1879 , easily distinguishable by the black pronotum and much shorter distal portion of the median lobe of the aedeagus, with a long needle-shaped tip (Figs $50-51)$. 

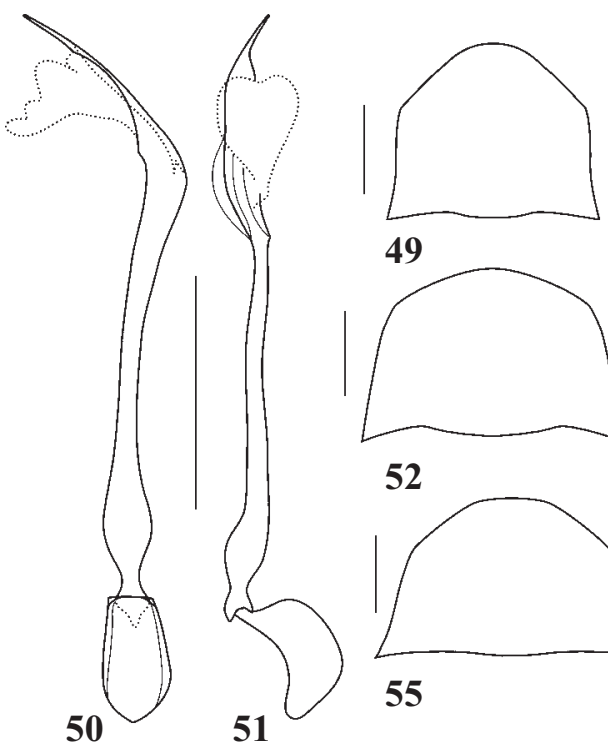

49

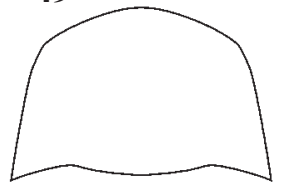

52

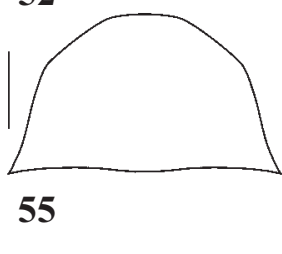

53

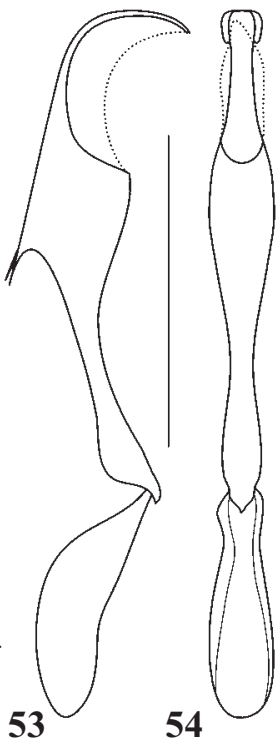

54

56
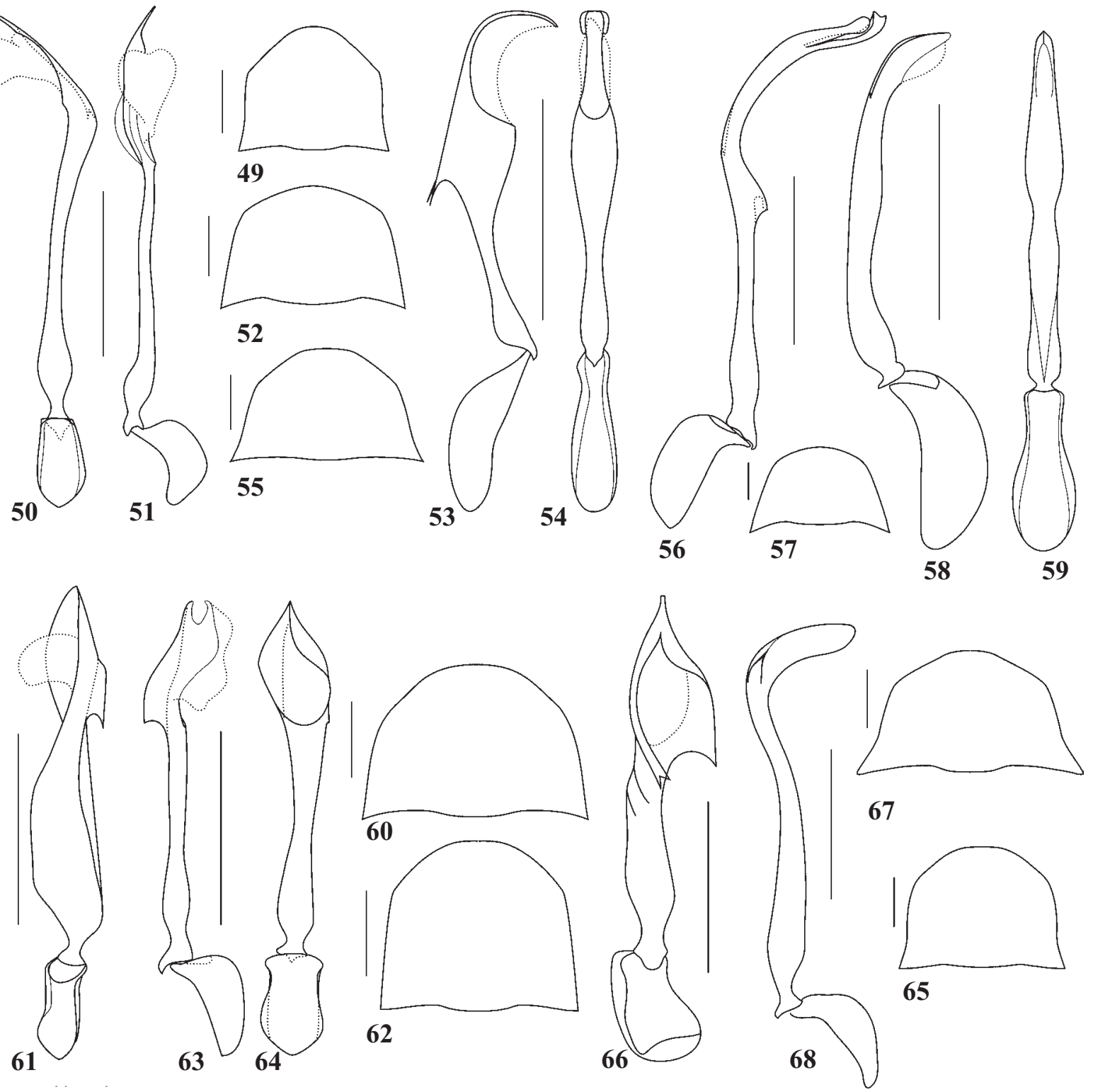

67

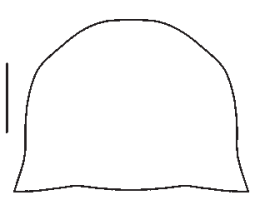

65

Figs 48-68. Details of Plateros spp., holotypes males: 48-51 - P. putaoensis sp.n.; 52-54 - P. weigeli sp.n.; 55-56-P. belokobylskyi sp.n.; 57-59- P. cinis sp.n.; 60-61 - P. cochinensis sp.n.; 62-64-P. deinceps sp.n.; 65-66 - P. dulcis sp.n.; 67-68 - P. faber sp.n.; 49, 52, 55, 57, 60, 62, 65, 67 - pronotum; 50-51, 53-54, 56, 58-59, 61, 63-64, 66, 68 — aedeagus. Scale bar: 5 mm.

Рис. 48-68. Детали строения Plateros spp., голотипы, самцы: 48-51 - P. putaoensis sp.n.; 52-54 - P. weigeli sp.n.; 55-56 - P. belokobylskyi sp.n.; 57-59 — P. cinis sp.n.; 60-61 - P. cochinensis sp.n.; 62-64 - P. deinceps sp.n.; 65-66 - P. dulcis sp.n.; 67-68 P. faber sp.n.; 49, 52, 55, 57, 60, 62, 65, 67 - переднеспинка; 50-51, 53-54, 56, 58-59, 61, 63-64, 66, 68 - эдеагус. Масштабная линейка: 5 мм.

\section{Plateros weigeli Kazantsev sp.n.}

Figs 52-54

MATERIAL: Holotype, $\bigcirc^{7}$, Nepal, Prov. Bheri, 15 km W Kusum, $28^{\circ} 02^{\prime} 15^{\prime \prime} \mathrm{N} \mathrm{81}{ }^{\circ} 57^{\prime} 16^{\prime \prime} \mathrm{E}$, deciduous forest, 13.VII.2001, A. Kopetz leg. (NKME); + , Nepal, Prov. Bheri, $15 \mathrm{~km}$ W Kusum, $28^{\circ} 02^{\prime} 15^{\prime \prime} \mathrm{N}$ $81^{\circ} 57^{\prime} 16^{\prime \prime} \mathrm{E}$, deciduous forest, $150 \mathrm{~m}, 13$.VII.2001, A. Weigel leg. (NKME).

DESCRIPTION. Male. Black. Pedicel brown; elytral proximal half (insignificantly extended along suture) testaceous.

Head dorsally with inconspicuous roundish impression behind antennal prominence, antennal sockets almost contiguous. Eyes relatively small (separated medially above by about 1.6 times their radius). Ultimate maxillary palpomere only slightly longer than wide, widest at middle. Antennae from antennomere 3 flattened, serrate, extending to elytral two thirds; antennomere 3 about 3.5 times longer than antennomere 2 and 1.2 times shorter than antennomere 4; antennomeres 3-11 with short erect pubescence.

Pronotum transverse, trapezoidal, 1.6 times wider than long, with noticeable anterior and acute posterior angles, anterior margin rounded, posterior margin conspicuously bisinuate (Fig. 52). Scutellum square, truncate at apex.

Elytra moderately long (2.75 times as long as wide humerally), slightly widened behind shoulders, with primary costa 4 more prominent in proximal third, otherwise primary 
costae hardly distinguishable from secondary ones; interstices with double rows of small roundish cells. Pubescence uniform, short and decumbent.

Aedeagus with widened distally median lobe, paired spine at base of preapical portion and paired curved dent at apex (Figs 53-54).

Female. Similar to male, but eyes smaller and antennae less serrate.

Length: 5.8-6.4 mm. Width (humerally): $1.7-1.9 \mathrm{~mm}$.

ETYMOLOGY. The new species is named after Mr. A Weigel, who collected one of the specimens of the type series.

DIAGNOSIS. $P$. weigeli sp.n. is similar to $P$. imitator Kleine, 1929, distinguishable by the black pronotum and differently arranged apex of the aedeagus (Figs 53-54).

\section{Plateros belokobylskyi Kazantsev sp.n.}

Figs 55-56

MATERIAL: Holotype, $\sigma^{7}$, Vietnam, Hoa Binh Prov., Yen Thai Distr., Lac Thinh, Cue Phuong N.P., 300 m, 20²3'N 105³4'E, 12.V.2002, S. Belokobylsky leg. (ICCM); paratypes: $\sigma^{7}$, Vietnam Hoa Binh Prov., Yen Thai Distr., Lac Thinh, Cue Phuong N.P., 300 m, 20²3'N 105³4'E, 5-6.V.2002, S. Belokobylsky leg.; $0^{\circ}$, Vietnam, Nin Binh Prov., Cue Phuong N.P., $200 \mathrm{~m}, 20^{\circ} 21^{\prime} \mathrm{N} 105^{\circ} 36^{\prime} \mathrm{E}$ 5-6.V.2002, S. Belokobylsky leg. (ICCM).

DESCRIPTION. Male. Black. Broad pronotal margins orange testaceous; elytra red.

Head dorsally with two inconspicuous impressions behind antennal prominence, antennal sockets separated by narrow lamina. Eyes relatively small (separated medially above by about 2 times their radius). Ultimate maxillary palpomere elongate, widest at middle, convex at distal margin. Antennae from antennomere 3 flattened, strongly serrate, extending to elytral middle; antennomere 3 about 3 times longer than antennomere 2 and 1.3 times shorter than antennomere 4; antennomeres 3-11 with short sub-erect pubescence and longer distal bristles.

Pronotum transverse, trapezoidal, 1.6 times wider than long, with obscure anterior and acute posterior angles, anterior margin rounded, posterior margin bisinuate (Fig. 55) Scutellum narrowed distally, feebly emarginate at apex.

Elytra long (3.25 times as long as wide humerally), parallel-sided, with primary costae 2 and 4 more prominent in proximal third; interstices with double rows of small roundish cells. Pubescence uniform, short, dense and decumbent.

Aedeagus with narrow bent distally median lobe, provided with dent in preapical portion (Fig. 56).

Length: $6.2-8.5 \mathrm{~mm}$. Width (humerally): $1.7-2.6 \mathrm{~mm}$.

Female. Unknown.

ETYMOLOGY. The new species is named after Dr. S. Belokobylsky, who collected the type series.

DIAGNOSIS. $P$. belokobylskyi sp.n. is similar to $P$. hoabinhensis Kazantsev, nom.n. or P. robustithorax Pic, 1923, distinguishable by the mostly infuscate or black pronotum and differently arranged median lobe of the aedeagus (Fig. 56)

VARIATION. In one of the paratypes the pronotum is entirely black.

\section{Plateros cinis Kazantsev sp.n.}

Figs 57-59

MATERIAL: Holotype, $\sigma^{7}$, Vietnam, Nin Binh Prov., Cue Phuong N.P., $200 \mathrm{~m}, 20^{\circ} 21^{\prime} \mathrm{N} 105^{\circ} 36^{\prime} \mathrm{E}, 5-6 . V .2002$, S. Belokobylsky leg. (ICCM); paratypes: $2 \sigma^{\top} \sigma^{\top}$, same label (ICCM); $\sigma^{7}$, "IndoChine, Pa-Kha, 1914, Dussault coll.” (MNHN); O', N Vietnam, Lao Cai Prov., Huang Lien Son Nat. Reservat, 1250 m, 15.VI.1998, A. Napolov leg. (NKME); , N Vietnam, N Hanoi, env. Sa Pa, Hoang Lien Son Nat. Park, 1250 m, 5-9.VI.1998, A. Napolov leg. (NKME).
DESCRIPTION. Male. Black. Pedicel distally brownish.

Head dorsally with inconspicuous roundish impression behind antennal prominence, antennal sockets separated by minute lamina. Eyes relatively small (separated medially above by about 2 times their radius). Ultimate maxillary palpomere elongate, slightly narrowing distally, convex at apex. Antennae from antennomere 3 flattened, narrow, slightly serrate, extending to elytral three fourths; antennomere 3 about 4 times longer than antennomere 2 and 1.25 times shorter than antennomere 4; antennomeres 3-11 with moderately long erect pubescence.

Pronotum transverse, trapezoidal, 1.6 times wider than long, with noticeable anterior and prominent acute posterior angles, posterior margin conspicuously bisinuate (Fig. 57). Scutellum square, truncate at apex.

Elytra moderately long (2.8 times as long as wide humerally), slightly widened behind shoulders, with primary costa 4 more prominent in proximal third; interstices with double rows of small subquadrate cells. Pubescence uniform, short and decumbent.

Aedeagus with slender median lobe of the aedeagus, constricted near apical part and curved near apex (Figs 58-59).

Female. Similar to male, but eyes smaller and antennae less serrate.

Length: 5.4-6.5 mm. Width (humerally): 1.3-1.9 mm.

ETYMOLOGY. The name of the new species is derived from the Latin for "cinder", alluding to its black coloration.

DIAGNOSIS. P. cinis sp.n. is similar to P. nitidus Pic, 1938, distinguishable by the prominent acute posterior pronotal angles and slenderer median lobe of the aedeagus, with a constriction near apical part and a more curved apex (Figs 58-59).

\section{Plateros cochinensis Kazantsev sp.n. Figs 60-61}

MATERIAL: Holotype, $\sigma^{7}$, S Vietnam, Gialai-Contum Prov., 8 km N Kon-Hanung, tropical forest, 23.VI.1983, L. Medvedev leg.

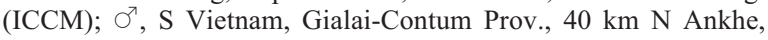
tropical forest, 30-31.X.1979, L. Medvedev leg. (ICCM).

DESCRIPTION. Male. Dark brown. Pedicel and elytral margins, including distal half of suture, light brown.

Head dorsally with two inconspicuous impressions behind antennal prominence, antennal sockets almost contiguous. Eyes moderately large (separated medially above by about 1.5 times their radius). Ultimate maxillary palpomere elongate, parallel-sided, oblique and convex at apex. Antennae from antennomere 3 flattened, flabellate, extending to elytral three fifths; antennomere 3 about 3.75 times longer than antennomere 2 and subequal in length to antennomere 4; antennomeres 3-11 with long sub-erect pubescence and longer distal bristles.

Pronotum transverse, trapezoidal, 1.6 times wider than long, with rounded anterior margin and acute posterior angles, posterior margin conspicuously bisinuate (Fig. 60). Scutellum square, very feebly emarginate at apex.

Elytra moderately long (3.125 times as long as wide humerally), parallel-sided, with primary costae 2 and 4 slightly more prominent in proximal fifth; interstices with double rows of small subquadrate cells. Pubescence double, sparser, short and decumbent and denser, longer and erect.

Aedeagus with robust median lobe constricted near apex and provided with dent in apical part (Fig. 61).

Length: 6.6-6.8 mm. Width (humerally): 1.5-1.6 mm.

Female. Unknown.

ETYMOLOGY. The name of the new species is derived from the old name of the area, where the type series was collected. 
DIAGNOSIS. $P$. cochinensis sp.n. is similar to $P$. limbatus (Pic, 1926), distinguishable by the less transverse pronotum (Fig. 60) and flabellate antennae.

\section{Plateros deinceps Kazantsev sp.n. \\ Figs 62-64}

MATERIAL: Holotype, $\sigma^{7}$, Vietnam, Hoa Binh Prov., Mai Chan Distr., Pa Co, 1100-1200 m, 20 $0^{\circ} 45^{\prime} \mathrm{N} 104^{\circ} 54^{\prime} \mathrm{E}, 27-$ 28.IV.2002, S. Belokobylsky leg. (ICCM); paratype, $0^{7}$, Vietnam, Hoa Binh Prov., Mai Chan Distr., Hang Kia, 1300 m, 204 $44^{\prime} \mathrm{N}$ 104'53'E, 25-26.IV.2002, S. Belokobylsky leg. (ICCM).

DESCRIPTION. Male. Black. Narrow anterior pronotal margin light brown.

Head dorsally with conspicuous roundish impression behind antennal prominence, antennal sockets separated by minute lamina. Eyes relatively large (separated medially above by about 1.25 times their radius). Ultimate maxillary palpomere elongate, parallel-sided, oblique and convex at apex. Antennae from antennomere 3 slightly flattened, parallel-sided, extending to elytral two thirds; antennomere 3 about 1.5 times longer than antennomere 2 and 1.8 times shorter than antennomere 4; antennomeres 3-11 with short erect pubescence and longer distal bristles.

Pronotum transverse, trapezoidal, 1.3 times wider than long, with obscure anterior and small acute posterior angles, anterior margin roundly produced forward, posterior margin inconspicuously bisinuate (Fig. 62). Scutellum square, truncate at apex.

Elytra moderately long (3.6 times as long as wide humerally), parallel-sided, with four equally developed primary costa; interstices with double rows of small roundish cells. Pubescence uniform, short and erect.

Aedeagus with almost straight and widened distally median lobe (Figs 63-64).

Length: $5.8-6.1 \mathrm{~mm}$. Width (humerally): $1.4-1.5 \mathrm{~mm}$.

Female. Unknown.

ETYMOLOGY. The name of the new species is derived from the Latin for "next", alluding to its similarity to $P$. integer sp.n.

DIAGNOSIS. $P$. deinceps sp.n. is fairly similar to $P$. integer sp.n., distinguishable by the slightly lightened pronotal margins and more robust median lobe of the aedeagus (Figs 63-64).

\section{Plateros dulcis Kazantsev sp.n.}

Figs 65-66

MATERIAL: Holotype, $0^{7}$, N Vietnam, Hoa Binh (ICCM).

DESCRIPTION. Male. Dark brown. Pedicel distally and narrow pronotal margins light brown; elytra red.

Head dorsally with inconspicuous roundish impression behind antennal prominence, antennal sockets separated by minute lamina. Eyes small (separated medially above by about 2.5 times their radius). Ultimate maxillary palpomere only slightly longer than wide, widest near distal margin. Antennae from antennomere 3 flabellate, extending to elytral two thirds; flabellae of antennomeres 4-10 conspicuously longer than antennomeres; antennomere 3 about 4 times longer than antennomere 2 and 1.25 times shorter than antennomere 4; antennomeres 3-11 with long erect curly pubescence.

Pronotum transverse, trapezoidal, 1.2 times wider than long, with noticeable anterior and small acute posterior angles, anterior margin rounded, posterior margin almost straight (Fig. 65). Scutellum square, truncate at apex.

Elytra long (3.7 times as long as wide humerally), parallel-sided, with four equally developed primary costae; interstices with double rows of small subquadrate cells. Pubes- cence uniform, dense, short and decumbent.

Aedeagus with robust, widened distally median lobe, provided with screw structures in preapical part (Fig. 66).

Length: $7.5 \mathrm{~mm}$. Width (humerally): $1.9 \mathrm{~mm}$.

Female. Unknown.

ETYMOLOGY. The name of the new species is derived from the Latin for "nice", alluding to its vivid coloration.

DIAGNOSIS. $P$. dulcis sp.n. is similar to $P$. hoabinhensis Kazantsev, nom.n. (= binhanus Pic, 1925, homonym), distinguishable by the flabellate antennae and only marginally light brownish pronotum.

\section{Plateros faber Kazantsev sp.n. Figs 67-68}

MATERIAL: Holotype, $0^{7}$, N Vietnam, Lai Cai Prov., $28 \mathrm{~km} \mathrm{~W}$ $\mathrm{Sa} \mathrm{Pa}, 1600$ m, 2.VII.1997, C.-F. Lee leg. (ICCM); paratype, o", same label (ICCM)

DESCRIPTION. Male. Black. Pedicel distally light brown

Head dorsally with roundish impression behind antennal prominence, antennal sockets nearly contiguous. Eyes relatively large (separated medially above by about their radius). Ultimate maxillary palpomere elongate, almost parallel-sided, truncate at apex. Antennae from antennomere 3 flabellate, extending to elytral three fourths; flabellae of antennomeres 4-10 subequal in length to antennomeres; antennomere 3 about 3.2 times longer than antennomere 2 and 1.25 times shorter than antennomere 4; antennomeres 3-11 with long erect curly pubescence.

Pronotum strongly transverse, 1.9 times wider than long, trapezoidal, with noticeable anterior and acute posterior angles, anterior margin almost triangularly produced forward, posterior margin bisinuate (Fig. 67). Scutellum square, truncate at apex.

Elytra long (3.3 times as long as wide humerally), parallel-sided, with four equally developed primary costae; interstices with double rows of small subquadrate cells. Pubescence uniform, short and decumbent.

Aedeagus with conspicuously curved apex of median lobe (Fig. 68).

Length: 7.2-7.3 mm. Width (humerally): $1.75-1.8 \mathrm{~mm}$.

Female. Unknown.

ETYMOLOGY. The name of the new species is derived from the Latin for "blackmith", alluding to its uniformly black coloration.

DIAGNOSIS. $P$. faber sp.n. is somewhat similar to $P$. nitidus Pic, 1938 or $P$. cinis sp.n., distinguishable by the flabellate antennae and more curved apex of the aedeagus (Fig. 68).

\section{Plateros fedorenkoi Kazantsev sp.n. Figs 68-70}

MATERIAL: Holotype, $\sigma^{\top}, \mathrm{S}$ Vietnam, Lam Dong Prov., Bi Doup-Nui Da Reserve, $12^{\circ} 10^{\prime} 44^{\prime \prime} \mathrm{N} 108^{\circ} 40^{\prime} 44^{\prime \prime} \mathrm{E}, 1400-1600 \mathrm{~m}$, at light, IV.2008, D. Fedorenko leg. (ICCM).

DESCRIPTION. Male. Black. Elytra with broad testaceous band in posterior two thirds (Fig. 69).

Head dorsally with broad roundish impression behind antennal prominence, antennal sockets almost contiguous. Eyes moderately large (separated medially above by about their radius). Ultimate maxillary palpomere elongate, almost parallel-sided, convex at apex. Antennae from antennomere 3 flattened, narrow, serrate, extending to elytral two thirds; antennomere 3 about 3 times longer than antennomere 2 and 1.3 times shorter than antennomere 4; antennomeres 3-11 with moderately long erect pubescence (Fig. 69). 


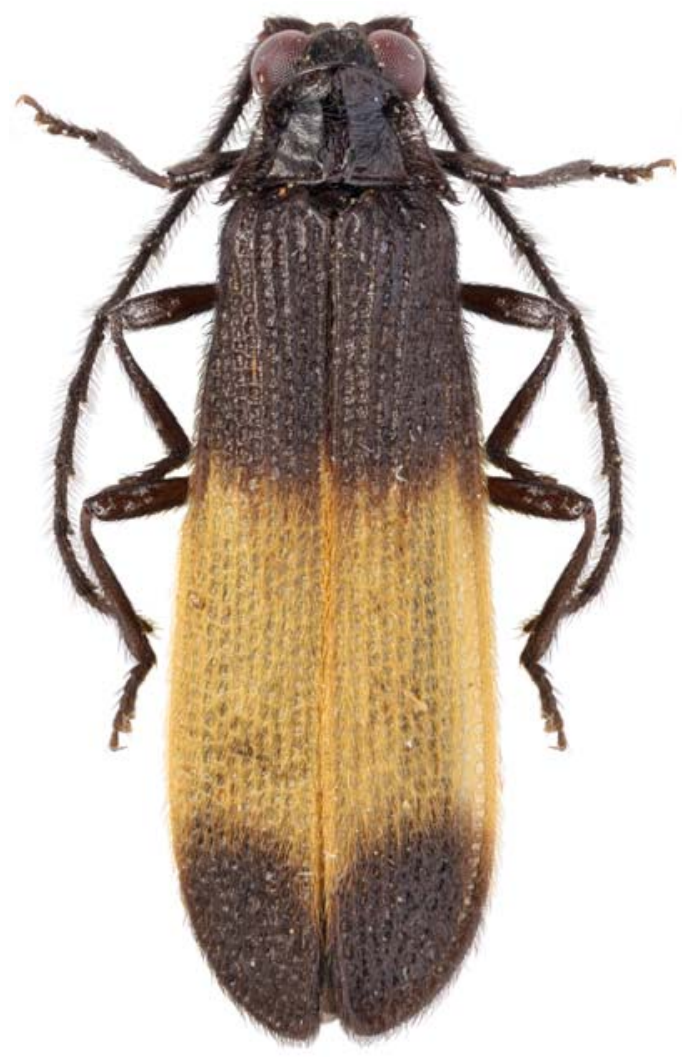

69
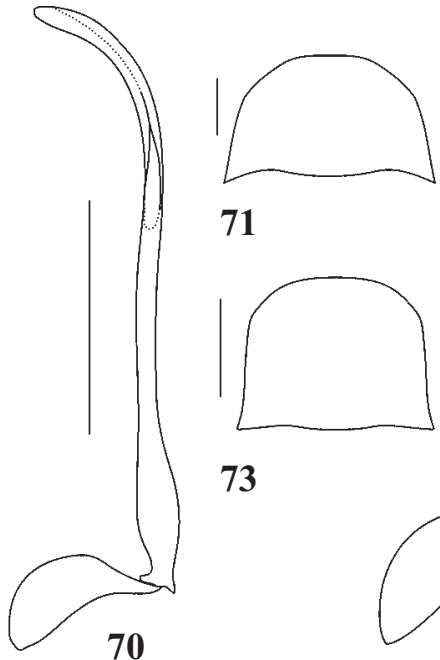

71

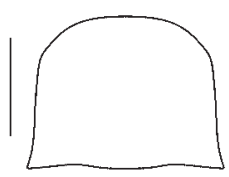

73
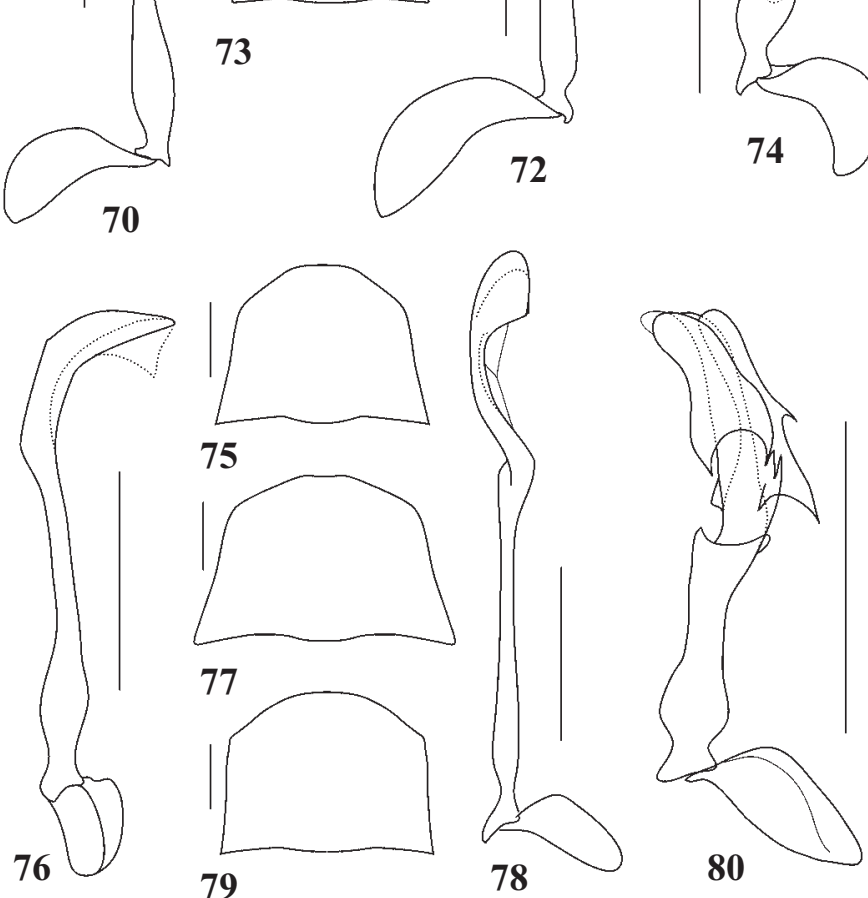

80

Figs 68-80. General view and details of Plateros spp., holotypes males: $68-70-$ P. fedorenkoi sp.n.; 71-72 - P. igneus sp.n.; 73$74-P$. innitidus sp.n.; 75-76 - P. integer sp.n.; 77-78 - P. kabakovi sp.n.; 78-80 - P. kradungensis sp.n.; $69-$ general view $(1=$ $6.2 \mathrm{~mm}) ; 71,73,75,77,79$ - pronotum; 70, 72, 74, 76, 78, 80 — aedeagus. Scale bar: $5 \mathrm{~mm}$.

Рис. 68-80. Общий вид и детали строения Plateros spp., голотипы, самцы: 68-70-P. fedorenkoi sp.n.; 71-72 - P. igneus sp.n.; 73-74 — P. innitidus sp.n.; 75-76 - P. integer sp.n.; 77-78 - P. kabakovi sp.n.; 78-80 — P. kradungensis sp.n.; 69 — общий вид (1 $=6.2$ мм); 71, 73, 75, 77, 79 - переднеспинка; 70, 72, 74, 76, 78, 80 - эдеагус. Масштабная линейка: 5 мм.

Pronotum strongly transverse, 1.9 times wider than long, almost triangular, with rounded anterior margin and prominent acute posterior angles, posterior margin inconspicuously bisinuate (Fig. 69). Scutellum square, truncate at apex.

Elytra long (3.7 times as long as wide humerally), very slightly widened in distal half (Fig. 69), with four equally developed primary costae; interstices with double rows of small subquadrate cells. Pubescence uniform, short and decumbent.

Aedeagus long and slender, with symmetric median lobe, slightly bent apically, with preapical openings on each side (Fig. 70).

Length: $6.2 \mathrm{~mm}$. Width (humerally): $1.5 \mathrm{~mm}$.

Female. Unknown.

ETYMOLOGY. The new species is named after Dr. D. Fedorenko, who collected the unique type specimen.

DIAGNOSIS. Very unlike all other Plateros species of the area due to its black upperside with broad yellow elytral band (Fig. 69), P. fedorenkoi sp.n. is similar to P. faber sp.n. in the male genital structure, distinguishable by the much slenderer and less curved distally median lobe of the aedeagus (Fig. 70).

\section{Plateros igneus Kazantsev sp.n. Figs 71-72}

MATERIAL: Holotype, $0^{7}$, NE Thailand, Loei Prov., Phu Kradung N.P., $16^{\circ} 53^{\prime} \mathrm{N} 101^{\circ} 47^{\prime} \mathrm{E}, 1300 \mathrm{~m}, 11-15 . V .1999$, D. Hauck leg. (ICCM).

DESCRIPTION. Male. Black. Pronotum, except for pair of elongate discal spots, and scutellum distally orange testaceous; elytra red.

Head dorsally with transverse impression behind antennal prominence, antennal sockets separated by minute lamina. Eyes small (separated medially above by about 2.5 times their radius). Ultimate maxillary palpomere elongate, widening distally, convex at apex. Antennae from antennomere 3 flattened, strongly serrate, extending to elytral middle; antennomere 3 about 2.4 times longer than antennomere 2 and 1.3 
times shorter than antennomere 4; antennomeres 3-11 with short erect pubescence.

Pronotum strongly transverse, 1.7 times wider than long, trapezoidal, with noticeable anterior and acute posterior angles, posterior margin bisinuate (Fig. 71). Scutellum transverse, rectangular, slightly emarginate at apex.

Elytra long (3.2 times as long as wide humerally), parallel-sided, only slightly widened behind shoulders, with four equally developed primary costae; interstices with double rows of small quadrate cells. Pubescence uniform, short and decumbent.

Aedeagus with conspicuously bent distal portion of median lobe, provided with noticeable spine in preapical area (Fig. 72).

Length: $8.0 \mathrm{~mm}$. Width (humerally): $2.1 \mathrm{~mm}$.

Female. Unknown.

ETYMOLOGY. The name of the new species is derived from the Latin for "burning", alluding to its bright reddish orange coloration.

DIAGNOSIS. $P$. igneus sp.n. seems to be related to $P$. belokobylskyi sp.n., distinguishable by the more orange pronotum, as well as by the conspicuously more bent distal portion of the median lobe of the aedeagus, with a noticeable spine in the preapical area (Fig. 72).

\section{Plateros innitidus Kazantsev sp.n. Figs 73-74}

MATERIAL: Holotype, $\mathrm{O}^{7}$, C Laos, Ban Phabat, $70 \mathrm{~km} \mathrm{~N}$ Vientiane, $150 \mathrm{~m}, 18^{\circ} 16.1^{\prime} \mathrm{N} 103^{\circ} 10.9^{\prime} \mathrm{E}, 27-30 . I V .1997$, Strb \& Hergovits leg. (ICCM); paratypes: $\sigma^{7}$, same label; $O^{7}$, N Thailand, Nan Prov., Bo Klua, $19^{\circ} 08^{\prime} \mathrm{N} 101^{\circ} 10^{\prime} \mathrm{E}, 700 \mathrm{~m}, 22$ 26.IV.1999, D. Hauck leg. (ICCM); O', Cambodia, Angkor Thom, sweeping, 23.V.2003, J Constant, K. Smet \& P. Grootaert leg. (IRSN).

DESCRIPTION. Male. Black. Narrow anterior and lateral pronotal margins testaceous.

Head dorsally with conspicuous roundish impression behind antennal prominence, antennal sockets separated by minute lamina. Eyes small (separated medially above by about 2.5 times their radius). Ultimate maxillary palpomere elongate, almost parallel-sided. Antennae from antennomere 3 flattened, strongly serrate, almost attaining elytral apices; antennomere 3 about 4 times longer than antennomere 2 and subequal in length to antennomere 4; antennomeres 3-11 with relatively long erect pubescence.

Pronotum transverse, trapezoidal, 1.4 times wider than long, with obscured anterior and small acute posterior angles, anterior margin rounded, posterior margin bisinuate (Fig. 73). Scutellum square, feebly emarginate at apex.

Elytra long ( 3 times as long as wide humerally), parallelsided, with four equally developed primary costae; interstices with double rows of small roundish cells. Pubescence uniform, short and decumbent.

Aedeagus with straight robust proximal and narrow spiral distal portions of median lobe, with long outer groove in its spiral part (Fig. 74)

Length: 4.8-5.4 mm. Width (humerally): $1.3-1.4 \mathrm{~mm}$.

Female. Unknown.

ETYMOLOGY. The name of the new species is derived from the Latin for "not" and "nitidus", the name of a Plateros species, with which it has certain resemblance, but very little in common.

DIAGNOSIS. P. innitidus sp.n. resembles $P$. nitidus Pic, 1938 by the shape of pronotum but is easily distinguishable by the brownish pronotal margins, serrate antennae and spiral median lobe of the aedeagus (Fig. 74).

\section{Plateros integer Kazantsev sp.n. Figs 75-76}

MATERIAL: Holotype, $\sigma^{7}$, Vietnam, Hoa Binh Prov., Mai Chan Distr., Pa Co, 1100-1200 m, 20 $45^{\prime} \mathrm{N} 104^{\circ} 54^{\prime} \mathrm{E}, 27-$ 28.IV.2002, S. Belokobylsky leg. (ICCM).

DESCRIPTION. Male. Black.

Head dorsally with inconspicuous transverse impression behind antennal prominence, antennal sockets almost contiguous. Eyes small (separated medially above by about 1.8 times their radius). Ultimate maxillary palpomere elongate, almost parallel-sided, convex at apex. Antennae from antennomere 3 slightly flattened, narrow, almost parallel-sided, extending to elytral two thirds; antennomere 3 about 1.8 times longer than antennomere 2 and 1.8 times shorter than antennomere 4; antennomeres 3-11 with short sub-erect pubescence and longer distal bristles.

Pronotum transverse, 1.25 times wider than long, slightly trapezoidal, with noticeable anterior and small acute posterior angles, anterior margin produced forward, posterior margin bisinuate (Fig. 75). Scutellum elongate, feebly emarginate at apex.

Elytra long (3.5 times as long as wide humerally), parallel-sided, with four equally developed primary costae; interstices with double rows of small roundish cells. Pubescence uniform, short and decumbent.

Aedeagus with narrow, slightly widened distally and pointed at apex median lobe (Fig. 76).

Length: $6.3 \mathrm{~mm}$. Width (humerally): $1.4 \mathrm{~mm}$.

Female. Unknown.

ETYMOLOGY. The name of the new species is derived from the Latin for "immaculate", alluding to its uniformly black coloration.

DIAGNOSIS. $P$. integer sp.n. is similar to $P$. nitidus Pic, 1938, distinguishable by the acute posterior pronotal angles and more complexly arranged apex of the aedeagus (Fig. 76).

\section{Plateros kabakovi Kazantsev sp.n. Figs 77-78}

MATERIAL: Holotype, $\sigma^{7}$, Vietnam, mountains by $\mathrm{Sa} \mathrm{Pa}$, 1600-2000 m, 5.VIII.1962, O. Kabakov leg. (ICCM); paratype,,$+ \mathrm{N}$ Vietnam, Lao Cai Prov., Hoang Lien Son Mt. Range, env. Fansipan, Tram Ton, 1950-2100 m, VII.2007, D. Fedorenko leg. (ICCM).

DESCRIPTION. Male. Black. Pronotum reddish testaceous, with elongate fuscous median spot; elytra red, with fuscous longitudinal stripes.

Head dorsally with conspicuous roundish impression behind antennal prominence, antennal sockets almost contiguous. Eyes moderately large (separated medially above by about 1.4 times their radius). Ultimate maxillary palpomere elongate, parallel-sided, distally oblique. Antennae from antennomere 3 flabellate, extending to elytral three fourths; flabellae of antennomeres 4-10 somewhat shorter than antennomeres; antennomere 3 about 4 times longer than antennomere 2 and 1.1 times shorter than antennomere 4; antennomeres 3-11 with long erect curly pubescence.

Pronotum transverse, 1.4 times wider than long, trapezoidal, with well noticeable anterior and prominent acute posterior angles, anterior margin triangularly produced forward, posterior margin bisinuate (Fig. 77). Scutellum square, feebly emarginate at apex.

Elytra long (3.25 times as long as wide humerally), parallel-sided, with primary costa 4 more prominent in proximal fourth; interstices with double rows of small subquadrate cells. Pubescence uniform, short and decumbent.

Aedeagus with almost straight median lobe, slightly twisted near apex (Fig. 78). 
Female. Similar to male, but eyes somewhat smaller and antennae only broadly serrate.

Length: 7.5-10.0 mm. Width (humerally): $2.1-2.5 \mathrm{~mm}$.

ETYMOLOGY. The new species is named after Dr. O. Kabakov, who collected one of the specimens of the type series.

DIAGNOSIS. P. kabakovi sp.n. resembles $P$. tonkineus Pic, 1926, differing by the flabellate antennae, fuscous longitudinal stripes at the proximal two thirds of elytral interstices and differently arranged apex of the aedeagus (Fig. 78).

\section{Plateros kradungensis Kazantsev sp.n.} Figs 78-80

MATERIAL: Holotype, $0^{7}$, NE Thailand, Loei Prov., Phu Kradung N.P., $16^{\circ} 52^{\prime} \mathrm{N} 101^{\circ} 49^{\prime} \mathrm{E}, 1000 \mathrm{~m}, 16-17 . V .1999$, D. Hauck leg. (ICCM); paratypes, 4 우, same label (ICCM).

DESCRIPTION. Male. Black. Pedicel and anterior and lateral margins of pronotum light brown.

Head dorsally with noticeable roundish impression behind antennal prominence, antennal sockets separated by minute lamina. Eyes moderately large (separated medially above by about 1.4 times their radius). Ultimate maxillary palpomere elongate, almost parallel-sided, convex at apex. Antennae from antennomere 3 flattened, serrate, extending to elytral two thirds; antennomere 3 about 4 times longer than antennomere 2 and 1.25 times shorter than antennomere 4 ; antennomeres 3-11 with relatively long erect pubescence.

Pronotum transverse, 1.4 times wider than long, somewhat trapezoidal, with prominent anterior and small acute posterior angles, anterior margin produced forward, posterior margin inconspicuously bisinuate (Fig. 79). Scutellum square, feebly emarginate at apex.

Elytra long (3.8 times as long as wide humerally), parallel-sided, with primary costa 4 slightly more elevated in most of its length, other primary costae hardly distinguishable from secondary ones; interstices with double rows of small roundish cells. Pubescence uniform, short and decumbent.

Aedeagus with short robust median lobe, provided with two hood-like structures and numerous dents in apical part (Fig. 80).

Female. Similar to male, but eyes smaller and antennae broader.

Length: $4.6-5.7 \mathrm{~mm}$. Width (humerally): $1.0-1.3 \mathrm{~mm}$.

ETYMOLOGY. The name of the new species is derived from the national park in Thailand, where the type series was collected.

DIAGNOSIS. $P$. kradungensis sp.n. belongs to the $P$. chapaensis Pic, 1923 group of species, differing by the short and complexly arranged median lobe of the aedeagus (Fig. 80).

\section{Plateros laocaensis Kazantsev sp.n.} Figs 81-83

MATERIAL: Holotype, $0^{7}$, N Vietnam, Lao Cai Prov., Hoang Lien Son Mt. Range, env. Fansipan, Tram Ton, 1950-2100 m, VII.2007, D. Fedorenko leg. (ICCM); paratypes: $2 \mathrm{O}^{7} \mathrm{O}^{7}$ and,$+ \mathrm{N}$ Vietnam, Lai Cai Prov., 28 km W Sa Pa, 1600 m, 2.VII.1997, C.-F. Lee leg. (ICCM)

DESCRIPTION. Male. Uniformly black.

Head dorsally with roundish impression behind antennal prominence, antennal sockets almost contiguous. Eyes relatively small (separated medially above by about 1.9 times their radius). Ultimate maxillary palpomere elongate, widest at middle. Antennae from antennomere 3 slightly flattened, narrow, lightly serrate, extending to elytral three fourths; antennomere 3 about 2.4 times longer than antennomere 2 and 1.3 times shorter than antennomere 4 ; antennomeres 3 11 with short erect pubescence.

Pronotum transverse, 1.5 times wider than long, trapezoidal, with inconspicuous anterior and prominent acute poste- rior angles, anterior margin rounded, posterior margin conspicuously bisinuate (Fig. 81). Scutellum square, very feebly emarginate at apex.

Elytra long (3.6 times as long as wide humerally), parallel-sided, with primary costa 4 more prominent in humeral area, other primary costae hardly distinguishable from secondary ones; interstices with double rows of small quadrate cells. Pubescence uniform, short and decumbent.

Aedeagus with sub-symmetric, elongate, bidentate preapically median lobe (Figs 82-83).

Female. Similar to male, but eyes smaller and antennae shorter.

Length: $6.2-6.6 \mathrm{~mm}$. Width (humerally): $1.4-1.6 \mathrm{~mm}$.

ETYMOLOGY. The name of the new species is derived from the province in Vietnam, where the type series was collected.

DIAGNOSIS. P. laocaensis sp.n. is somewhat similar to P. nitidus Pic, 1938, distinguishable by the prominent acute posterior pronotal angles and more elongate and bidentate preapically median lobe of the aedeagus (Figs 82-83).

\section{Plateros loeiensis Kazantsev sp.n. Figs 84-86}

MATERIAL: Holotype, $\sigma^{7}$, NE Thailand, Loei Prov., Phu Kradung N.P., $16^{\circ} 523^{\prime} \mathrm{N} 101^{\circ} 49^{\prime} \mathrm{E}, 1000 \mathrm{~m}, 16-17 . V .1999$, D. Hauck leg. (ICCM).

DESCRIPTION. Male. Black. Narrow pronotal margins light brown.

Head dorsally with small roundish impression behind antennal prominence, antennal sockets almost contiguous. Eyes moderately large (separated medially above by about 1.2 times their radius). Ultimate maxillary palpomere elongate, slightly narrowed before apex, convex distally. Antennae narrow, filiform, extending to elytral three fourths, from antennomere 3 lightly serrate; antennomere 3 about 4 times longer than antennomere 2 and 1.25 times shorter than antennomere 4; antennomeres 3-11 with long erect pubescence.

Pronotum transverse, 1.2 times wider than long, with straight sides, noticeable anterior and small acute posterior angles, anterior margin rounded, posterior margin almost straight (Fig. 84). Scutellum square, feebly emarginate at apex.

Elytra long (3.7 times as long as wide humerally), parallel-sided, with four equally developed primary costae, primary costae not much differing from secondary ones; interstices with double rows of small subquadrate cells. Pubescence uniform, short and decumbent.

Aedeagus symmetric, with short and apically hooded median lobe (Figs 85-86).

Length: $5.0 \mathrm{~mm}$. Width (humerally): $1.0 \mathrm{~mm}$.

Female. Unknown.

ETYMOLOGY. The name of the new species is derived from the province in Thailand, where the type specimen was collected.

DIAGNOSIS. P. loeiensis sp.n. resembles $P$. laocaensis sp.n., differing by the serrate antennae and shorter and apically hooded median lobe of the aedeagus (Figs 85-86).

\section{Plateros merulus Kazantsev sp.n. Figs 87-88}

MATERIAL: Holotype, O’, C Laos, Bolikhamsai, Ban Nape, Kaew Nua Pass, 500-700 m, 18²2.3'N 10509.1'E, 4-12.V.1997, Strba \& Hergovits leg. (ICCM).

DESCRIPTION. Male. Uniformly black.

Head dorsally with conspicuous roundish impression behind antennal prominence, antennal sockets almost contiguous. Eyes relatively small (separated medially above 

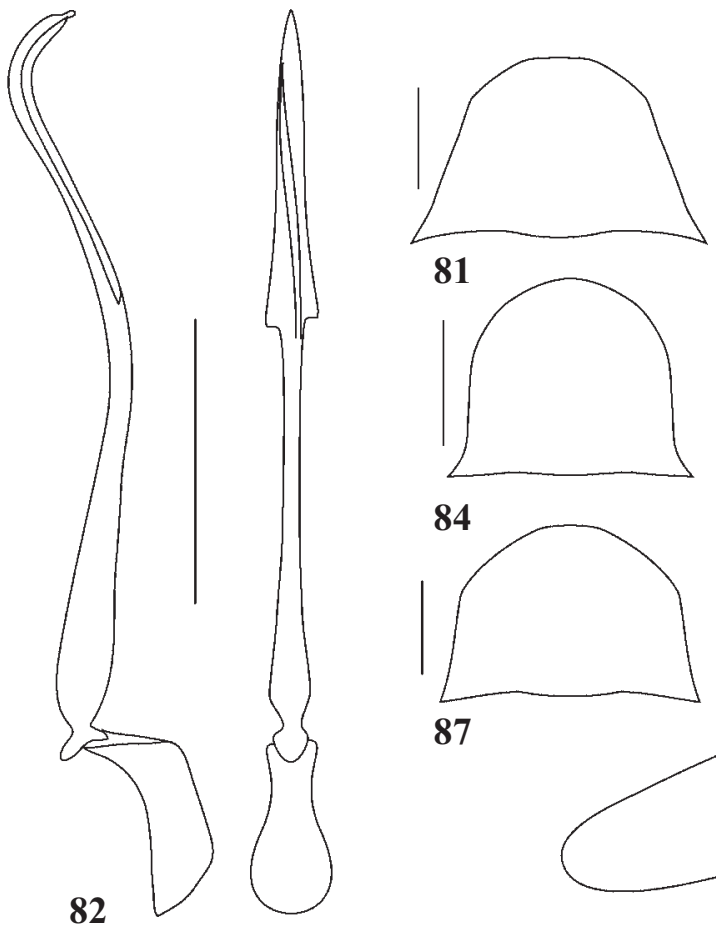

\section{4}

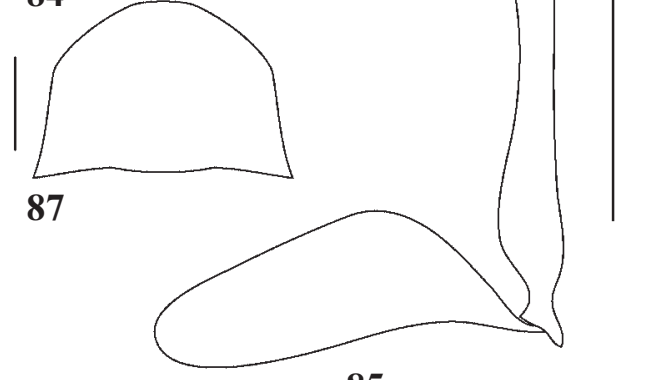

85

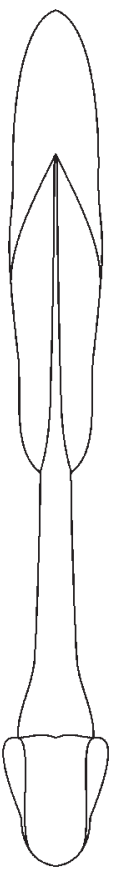

86

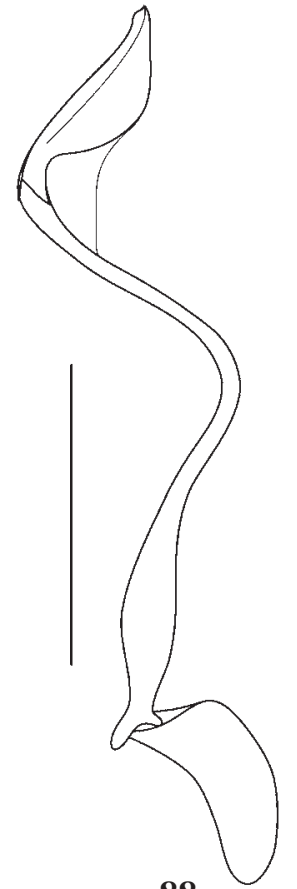

88

83
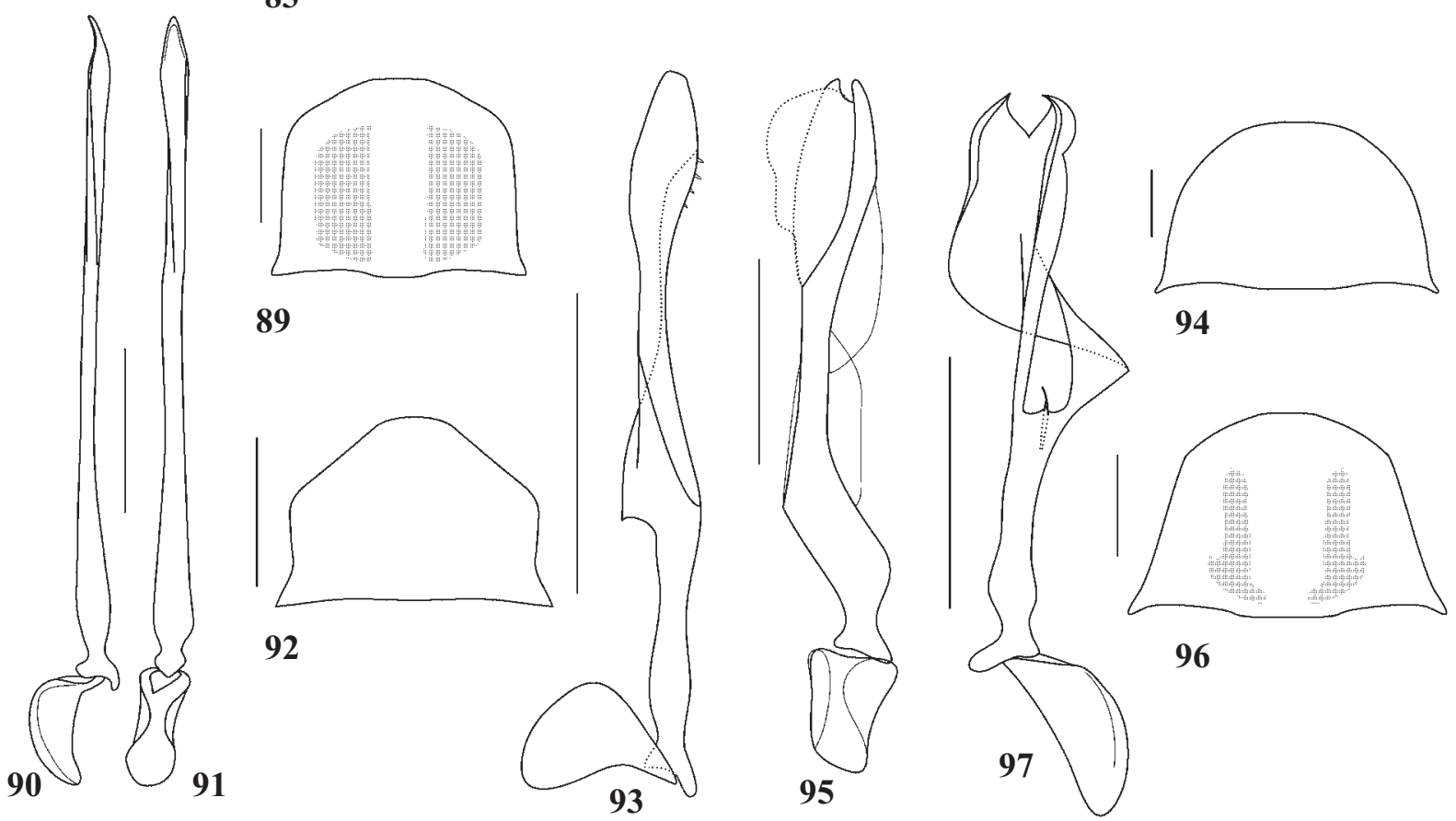

94

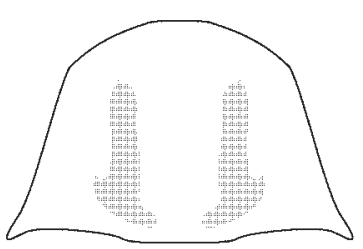

96

Figs 81-97. Details of Plateros spp., holotypes males: 81-83 - P. laocaensis sp.n.; 84-86 - P. loeiensis sp.n.; 87-88 - P. merulus sp.n.; 88-91 - P. nanensis sp.n.; 92-93 - P. nemo sp.n.; 94-95 - P. nonus sp.n.; 96-97 - P. orlovi sp.n.; 81, 84, 87, 89, 92, 94, 96 — pronotum; 82-83, 85-86, 88, 90-91, 93, 95, 97 - aedeagus. Scale bar: $5 \mathrm{~mm}$.

Рис. 81-97. Детали строения Plateros spp., голотипы, самцы: 81-83- P. laocaensis sp.n.; 84-86 - P. loeiensis sp.n.; 87-88 P. merulus sp.n.; 88-91 - P. nanensis sp.n.; 92-93 - P. nemo sp.n.; 94-95 - P. nonus sp.n.; 96-97 - P. orlovi sp.n.; 81, 84, 87, 89, 92, 94, 96 - переднеспинка; 82-83, 85-86, 88, 90-91, 93, 95, 97 - эдеагус. Масштабная линейка: 5 мм.

by about 2 times their radius). Ultimate maxillary palpomere elongate, almost parallel-sided, oblique and slightly convex at apex. Antennae extending to elytral three fourths, from antennomere 3 flabellate; flabellae of antennomeres
4-10 shorter than antennomeres; antennomere 3 about 2.8 times longer than antennomere 2 and 1.1 times shorter than antennomere 4; antennomeres 3-11 with long erect pubescence. 
Pronotum transverse, 1.4 times wider than long, trapezoidal, with noticeable anterior and acute posterior angles, posterior margin bisinuate (Fig. 87). Scutellum square, slightly emarginate at apex.

Elytra long (3.1 times as long as wide humerally), parallel-sided, with primary costa 4 slightly more prominent in proximal fourth; interstices with double rows of small quadrate cells. Pubescence uniform, short and decumbent.

Aedeagus with narrow spirally curved median lobe making ca. $270^{\circ}$ twist (Fig. 88).

Length: $5.8 \mathrm{~mm}$. Width (humerally): $1.4 \mathrm{~mm}$.

Female. Unknown.

ETYMOLOGY. The name of the new species is derived from the Latin for "blackbird", alluding to its uniformly black coloration.

DIAGNOSIS. P. merulus sp.n. is similar to $P$. faber sp.n., distinguishable by the spiral median lobe of the aedeagus (Fig. 88) The new species differs from $P$. assamicus (Kleine, 1929), also of similar coloration and antennal structure, by the narrower and more spirally twisted median lobe of the aedeagus.

\section{Plateros nanensis Kazantsev sp.n.} Figs 88-91

MATERIAL: Holotype, $0^{7}$, N Thailand, Nan Prov., Bo Klua, $19^{\circ} 08^{\prime} \mathrm{N} 101^{\circ} 10^{\prime}$ E, $700 \mathrm{~m}, 22-26 . I V .1999$, D. Hauck leg. (ICCM); paratypes: 2 오, same label; 2 오, NE Thailand, Loei Prov., Phu Kradung N.P., $15 \mathrm{~km} \mathrm{~W}$ Kusum, $16^{\circ} 53^{\prime} \mathrm{N} 101^{\circ} 47^{\prime} \mathrm{E}, 1300 \mathrm{~m}, 11$ 15.V.1999, D. Hauck leg. (ICCM).

DESCRIPTION. Male. Black. Pronotum, except for pair of longitudinal discal spots, orange testaceous; elytra red.

Head dorsally with two conspicuous impressions behind antennal prominence, antennal sockets separated by minute lamina. Eyes moderately large (separated medially above by about 1.5 times their radius). Ultimate maxillary palpomere elongate, widest at middle, convex at apex. Antennae from antennomere 3 flabellate; flabellae of antennomeres 4-10 longer than antennomeres; antennomere 3 about 3 times longer than antennomere 2 and subequal in length to antennomere 4; antennomeres 3-11 with long erect pubescence.

Pronotum transverse, 1.3 times wider than long, with almost straight sides, rounded anterior and small acute posterior angles, anterior margin somewhat triangularly produced forward, posterior margin bisinuate (Fig. 89). Scutellum square, slightly emarginate at apex.

Elytra long ( 3.5 times as long as wide humerally), slightly widened behind shoulders, with four equally developed primary costae; interstices with double rows of small quadrate cells. Pubescence uniform, dense, short and decumbent.

Aedeagus with long straight narrow median lobe (Figs 90-91).

Female. Similar to male, but larger and broader, eyes smaller and antennae strongly serrate.

Length: 7.2-10.6 mm. Width (humerally): $1.6-2.6 \mathrm{~mm}$.

ETYMOLOGY. The name of the new species is derived from the province in Thailand, where most of the type series was collected.

DIAGNOSIS. $P$. nanensis sp.n. somewhat resembles $P$. igneus sp.n., easily distinguishable by the flabellate antennae and long straight narrow median lobe of the aedeagus (Figs 90-91).

\section{Plateros nemo Kazantsev sp.n.} Figs 92-93

MATERIAL: Holotype, $0^{\top}$, Thailand, Changmai Zoo, $18^{\circ} 49^{\prime} \mathrm{N}$ 985'ㄹ, 400 m, 7-14.XI.1988, Chantaramongkol leg. (ICCM).

DESCRIPTION. Male. Black.

Head dorsally with inconspicuous round impression behind antennal prominence, antennal sockets almost contigu- ous. Eyes large (separated medially above by about 0.9 times their radius). Ultimate maxillary palpomere only slightly longer than wide, widest at middle. Antennae tapering distally, extending to elytral two thirds; from antennomere 3 flattened, strongly serrate, antennomere 3 about 3 times longer than antennomere 2 and subequal in length to antennomere 4; antennomeres 3-11 with relatively long erect pubescence.

Pronotum transverse, 1.3 times wider than long, with conspicuously concave sides, prominent anterior and acute posterior angles, anterior margin triangularly produced forward (Fig. 92). Scutellum square, slightly emarginate at apex.

Elytra long (3.8 times as long as wide humerally), parallel-sided, with primary costa 4 more prominent in humeral area; interstices with double rows of small subqyadrate cells. Pubescence uniform, short and sub-erect.

Median lobe of aedeagus with prominent tooth in middle and short minute spines in apical part (Fig. 93).

Length: $4.8 \mathrm{~mm}$. Width (humerally): $1.2 \mathrm{~mm}$.

Female. Unknown.

ETYMOLOGY. The name of the new species is derived from the Latin for "nobody", alluding to its commonly black coloration.

DIAGNOSIS. $P$. nemo sp.n. may be placed near $P$. nitidus Pic, 1938, distinguishable by the serrate antennae, prominent posterior pronotal angles and presence of a tooth in the middle of the median lobe of the aedeagus (Fig. 93).

\section{Plateros nonus Kazantsev sp.n. Figs 94-95}

MATERIAL: Holotype, $\sigma^{\top}$, Vietnam, Nin Binh Prov., Cue Phuong N.P., $200 \mathrm{~m}, 20^{\circ} 21^{\prime} \mathrm{N} 105^{\circ} 36^{\prime} \mathrm{E}, 5-6 . V .2002$, S. Belokoby1sky leg. (ICCM); paratypes: + , same label; $O^{\gamma}$ and + , Vietnam, Hoa Binh Prov., Yen Thai Distr., Lac Thinh, Cue Phuong N.P., 300 m, $20^{\circ} 23^{\prime} \mathrm{N} 105^{\circ} 34^{\prime} \mathrm{E}, 1-2 . V .2002$, S. Belokobylsky leg.; + , Vietnam, Hoa Binh Prov., Mai Chan Distr., Pa Co, $1100-1200 \mathrm{~m}, 20^{\circ} 45^{\prime} \mathrm{N}$ 10454'E, 18-21.IV.2002, S. Belokobylsky leg.; + , N Laos, 20 km NW Luang Namtha, 800-1000 m, 4-12.V.1997, Strba \& Hergovits leg.; $20^{7} \mathrm{O}^{7}$ and 2 \%o, $\mathrm{N}$ Laos, $15 \mathrm{~km}$ NW Luang Namtha, $750 \mathrm{~m}$, $21^{\circ} 07.5^{\prime} \mathrm{N} 101^{\circ} 21.0^{\prime} \mathrm{E}, 13-24 . V .1997$, Strba \& Hergovits leg.; $0^{\top}, \mathrm{C}$ Laos, Bolikhamsai, Ban Nape, Kaew Nua Pass, 500-700 m, $18^{\circ} 22.3^{\prime} \mathrm{N} 105^{\circ} 09.1^{\prime} \mathrm{E}, 18-30 . V .1998$, Strba \& Hergovits leg.; O' $^{\prime}$, Laos, Bolikhamxai Prov., Rd 8, $15 \mathrm{~km}$ from intersection with Rd 13, 200 m, 24.X.2003, S. Kurbatov leg. (ICCM).

DESCRIPTION. Male. Black. Pedicel distally light brown; pronotum and elytra orange testaceous.

Head dorsally with two inconspicuous impressions behind antennal prominence, antennal sockets separated by minute lamina. Eyes small (separated medially above by about 2 times their radius). Ultimate maxillary palpomere elongate, parallel-sided, oblique and convex at apex. Antennae extending to slightly over elytral middle; from antennomere 3 flattened, broad, serrate, antennomere 3 about 2.5 times longer than antennomere 2 and 1.2 times shorter than antennomere 4; antennomeres 3-11 with relatively long decumbent pubescence and long distal bristles.

Pronotum transverse, 1.5 times wider than long, semielliptical, with narrowly produced posterior angles (Fig. 94). Scutellum square, truncate at apex.

Elytra long (3.5 times as long as wide humerally), parallel-sided, slightly concave at sides, with four almost equally developed primary costae; interstices with double rows of mostly quadrate cells. Pubescence double, short and decumbent, and sparser, longer and sub-erect.

Aedeagus with robust, not spiral median lobe (Fig. 95).

Female. Similar to male, but eyes slightly smaller and antennae somewhat shorter.

Length: 8.0-10.2 mm. Width (humerally): 2.0-2.4 mm. 
ETYMOLOGY. The name of the new species is derived from the Latin for "ninth", as it appeared to be the ninth bright orange species of the area.

DIAGNOSIS. $P$. nonus sp.n. is rather similar to $P$. $b i$ foveiceps (Pic, 1921), distinguishable by the serrate, not flabellate, antennae and robust, not spiral median lobe of the aedeagus (Fig. 95).

VARIATION. In one of the paratypes the pronotum is entirely dark brown.

\section{Plateros orlovi Kazantsev sp.n. Figs 96-97}

MATERIAL: Holotype, $0^{7}$, Vietnam, Lao Cai Prov., Sa Pa Distr., Fan Si Pan Mt., 1900-2500 m, 20.IV-9.V.1999, N.L. Orlov leg. (ICCM).

DESCRIPTION. Male. Black. Pronotum, except in two narrow discal stripes, and elytra cinnabar red.

Head dorsally with conspicuous round impression behind antennal prominence, antennal sockets almost contiguous. Eyes small (separated medially above by about 2.2 times their radius). Ultimate maxillary palpomere elongate, widest at middle, convex at apex. Antennae tapering distally, extending to elytral two thirds; from antennomere 3 flattened, serrate, antennomere 3 about 2.4 times longer than antennomere 2 and 1.3 times shorter than antennomere 4; antennomeres 3-11 with short erect pubescence.

Pronotum transverse, 1.5 times wider than long, trapezoidal, with noticeable anterior and long acute posterior angles, posterior margin inconspicuously bisinuate (Fig. 96). Scutellum square, truncate at apex.

Elytra long (3.75 times as long as wide humerally and 6 times longer than pronotum), parallel-sided, with primary costa 4 slightly more prominent in proximal fourth; interstices with double rows of subquadrate cells. Pubescence uniform, short and decumbent.

Aedeagus with robust, provided with screw strictures and bifurcate apex median lobe (Fig. 97).

Length: $7.2 \mathrm{~mm}$. Width (humerally): $1.6 \mathrm{~mm}$.

Female. Unknown.

ETYMOLOGY. The new species is named after Mr. N. Orlov, who collected the unique type specimen.

DIAGNOSIS. $P$. orlovi sp.n. seems to be related to $P$. nonus sp.n., but differs by the narrower body and antennae, straight outer elytral margins and more dilated and twisted median lobe of the aedeagus (Fig. 97).

\section{Plateros pulverulentus Kazantsev sp.n. Figs 98-99}

MATERIAL: Holotype, $\sigma^{7}$, Vietnam, Tamdao, 14.IV.1986(ICCM)

DESCRIPTION. Male. Black. Pronotal margins narrowly light brown.

Head dorsally with two small impression behind antennal prominence, antennal sockets separated by minute lamina. Eyes small (separated medially above by about 2.3 times their radius). Ultimate maxillary palpomere elongate, parallelsided, convex at apex. Antennae extending to elytral three fourths; from antennomere 3 flattened, strongly serrate, antennomere 3 about 4.6 times longer than antennomere 2 and 1.1 times shorter than antennomere 4; antennomeres 3-11 with long erect curly pubescence.

Pronotum transverse, 1.4 times wider than long, slightly trapezoidal, with noticeable anterior and acute posterior angles, posterior margin bisinuate (Fig. 98). Scutellum square, emarginate at apex.

Elytra long (3.2 times as long as wide humerally), parallel-sided, with primary costa 4 slightly more elevated in proximal third; interstices with double rows of small subquadrate cells. Pubescence uniform, short and sub-erect.

Aedeagus with almost straight median lobe, with screwlike structures on its surface (Fig. 99).

Length: $5.4 \mathrm{~mm}$. Width (humerally): $1.3 \mathrm{~mm}$.

Female. Unknown.

ETYMOLOGY. The name of the new species is derived from the Latin for "dusty", alluding to its coloration.

DIAGNOSIS. $P$. pulverulentus sp.n. is similar to $P$. innitidus sp.n., distinguishable by the straighter median lobe of the aedeagus, with screw-like structures on its surface (Fig. 99).

\section{Plateros subplanatus Kazantsev sp.n. Figs 100-101}

MATERIAL: Holotype, $\mathrm{O}^{\top}$, N Vietnam, Lai Cai Prov., $28 \mathrm{~km} \mathrm{~W}$ $\mathrm{Sa} \mathrm{Pa}, 1600$ m, 2.VII.1997, C.-F. Lee leg. (ICCM); paratype, + , same label (ICCM)

DESCRIPTION. Male. Black.

Head dorsally with conspicuous longitudinal impression between antennal prominences, antennal sockets almost contiguous. Eyes moderately large (separated medially above by about 1.5 times their radius). Ultimate maxillary palpomere elongate, widest at middle, narrowing distally. Antennae narrow, tapering distally, extending to elytral three fourths; from antennomere 3 flattened, serrate, antennomere 3 about 4 times longer than antennomere 2 and 1.1 times shorter than antennomere 4; antennomeres 3-11 with short erect pubescence.

Pronotum transverse, 1.6 times wider than long, with triangularly produced anterior margin, concave sides, noticeable anterior and acute posterior angles (Fig. 100). Scutellum elongate, parallel-sided, truncate at apex.

Elytra long (3.75 times as long as wide humerally and 6 times longer than pronotum), parallel-sided, with four equally developed primary costae, hardly distinguishable from secondary ones; interstices with double rows of small subquadrate or roundish cells. Pubescence uniform, short and decumbent.

Aedeagus with almost straight narrow widened distally and pointed at apex median lobe (Fig. 101).

Female. Similar to male, but eyes smaller and antennae narrower and somewhat shorter.

Length: 5.8-7.6 mm. Width (humerally): $1.5-1.7 \mathrm{~mm}$.

ETYMOLOGY. The name of the new species is derived from the Latin for "after" and "planatus", the name of a Plateros species, which has a similar aedeagus.

DIAGNOSIS. $P$. subplanatus sp.n. is similar to $P$. planatus Waterhouse, 1879 in the shape of the male copulatory organs, distinguishable by the uniformly black body, larger eyes and more symmetric median lobe of the aedeagus (Fig. 101).

\section{Plateros tenebrosus Kazantsev sp.n. Figs 102-104}

MATERIAL: Holotype, $\sigma^{7}$, S Vietnam, N Dongnai, Nam Cat Tien N.P., 19.V-18.VI.2005, D. Fedorenko leg. (ICCM).

DESCRIPTION. Male. Black. Pronotum orange testaceous.

Head dorsally with inconspicuous shallow impression behind antennal prominence, antennal sockets separated by minute lamina. Eyes relatively small (separated medially above by about 1.75 times their radius). Ultimate maxillary palpomere elongate, widest at middle, slightly narrowing distally. Antennae extending to elytral two thirds; from antennomere 3 flattened, strongly serrate; antennomere 3 about 2.75 times longer than antennomere 2 and 1.1 times shorter than antennomere 4; antennomeres 3-11 with long erect pubescence. 

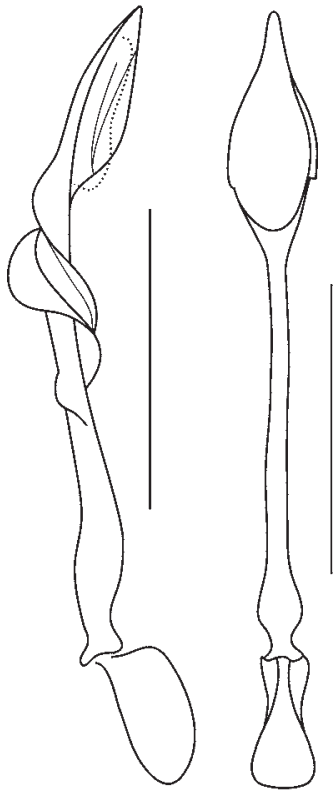

101

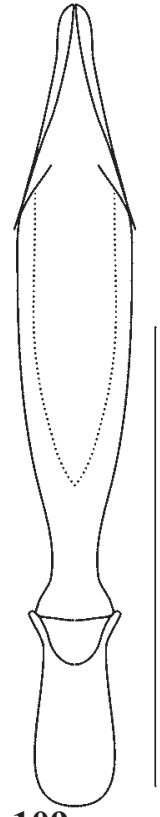

109

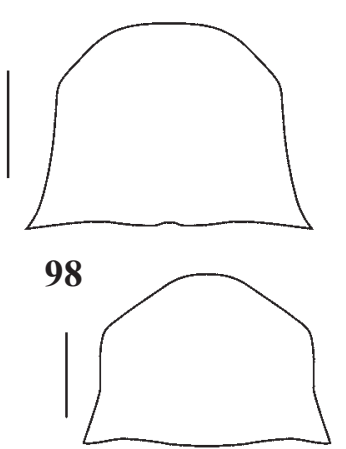

100

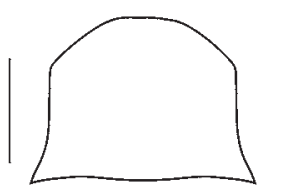

102
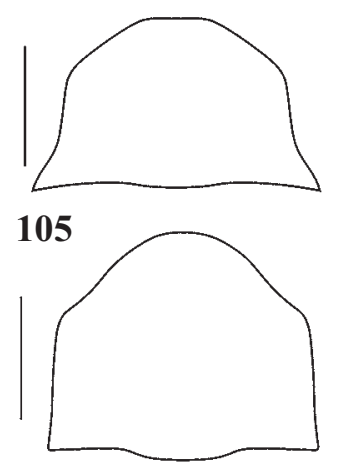

108

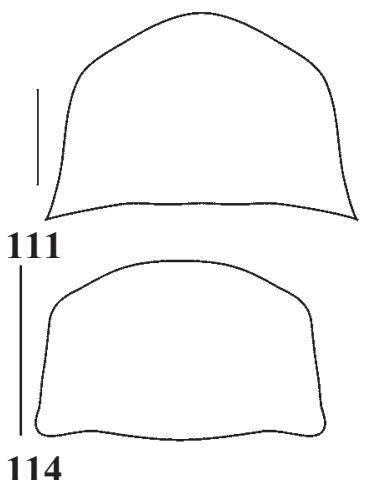

114
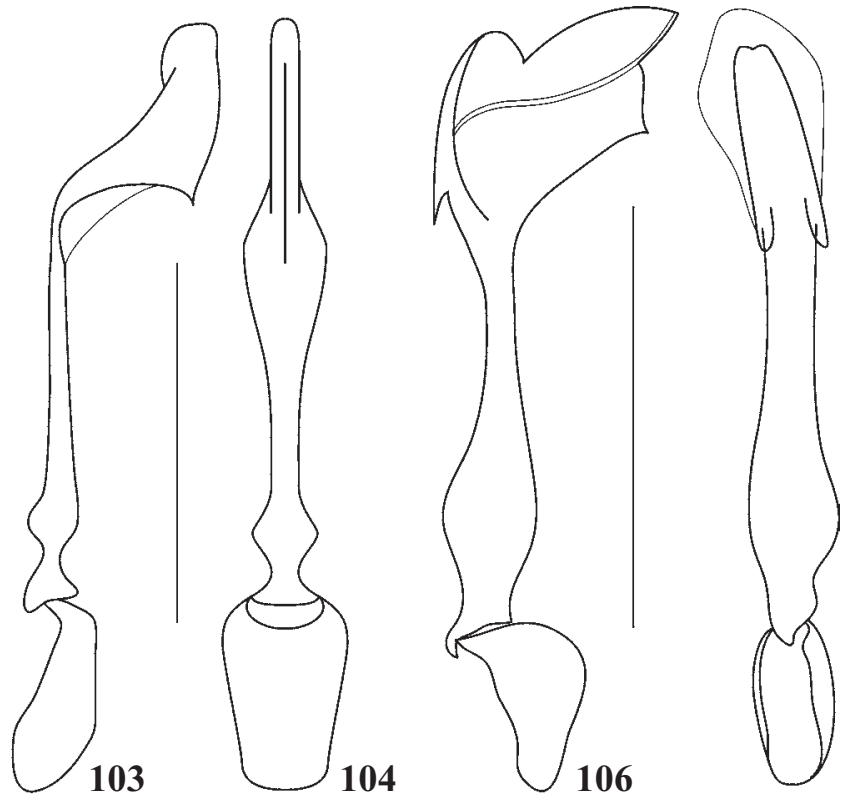

107

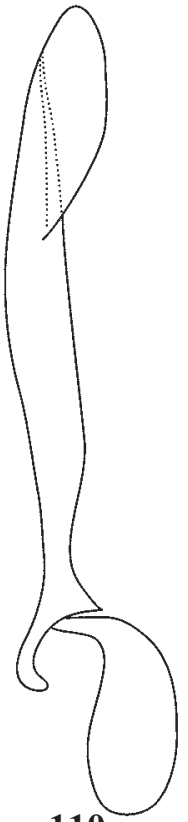

110

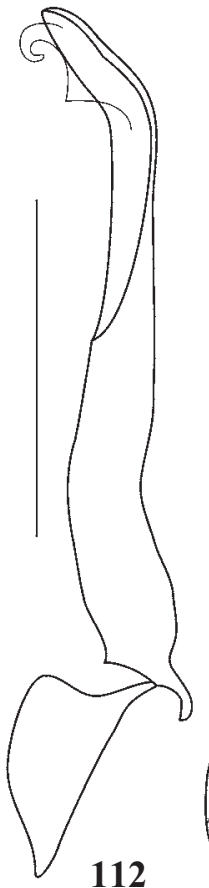

112

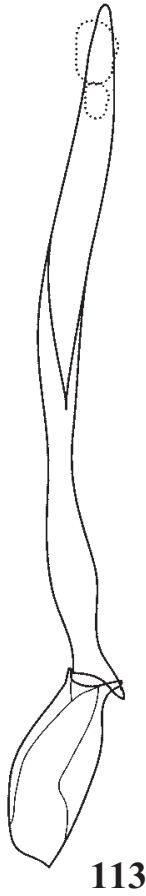

113

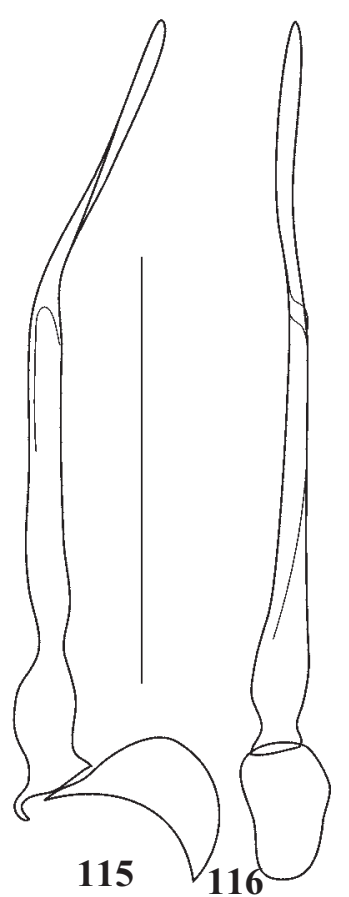

Figs 98-116. Details of Plateros spp., holotypes males: 98-99 - P. pulverulentus sp.n.; 100-101 - P. subplanatus sp.n.; 102-104 — P. tenebrosus sp.n.; 105-107 - P. bruggei sp.n.; 108-110 - P. grootaerti sp.n.; 111-113 - P. holynskiorom sp.n.; 114-116 - P. indentatus sp.n.; 98, 100, 102, 105, 108, 111, 114 — pronotum; 99, 101, 103-104, 106-107, 108-110, 112-113 - aedeagus. Scale bar: $5 \mathrm{~mm}$.

Рис. 98-116. Детали строения Plateros spp., голотипы, самцы: 98-99 - P. pulverulentus sp.n.; 100-101 - P. subplanatus sp.n.; 102-104 - P. tenebrosus sp.n.; 105-107 - P. bruggei sp.n.; 108-110 - P. grootaerti sp.n.; 111-113 - P. holynskiorom sp.n.; 114116 - P. indentatus sp.n.; 98, 100, 102, 105, 108, 111, 114 - переднеспинка; 99, 101, 103-104, 106-107, 108-110, 112-113 — эдеагус. Масштабная линейка: 5 мм.

Pronotum transverse, 1.5 times wider than long, with straight sides, noticeable anterior and acute posterior angles (Fig. 102). Scutellum square, truncate at apex.

Elytra long (3.3 times as long as wide humerally), parallel-sided, with four almost equally developed primary costae, not much distinguishable from secondary ones; interstices with double rows of small roundish cells. Pubescence uniform, short and decumbent.

Aedeagus symmetric, with narrow median lobe; narrow apical hood with pair of spines (Figs 103-104).

Length: $4.3 \mathrm{~mm}$. Width (humerally): $1.1 \mathrm{~mm}$.

Female. Unknown. 
ETYMOLOGY. The name of the new species is derived from the Latin for "dark", alluding to its coloration.

DIAGNOSIS. $P$. tenebrosus sp.n. is somewhat similar to $P$. loeiensis sp.n., distinguishable by the uniformly orange testaceous pronotum and narrower median lobe of the aedeagus, the apical hood of which bears a pair of spines (Figs 103-104).

\section{Plateros bruggei Kazantsev sp.n.}

Figs 105-107

MATERIAL: Holotype, $\sigma^{\top}$, Neth. New Guinea, Hollandia, rain forest, $250 \mathrm{ft}, \mathrm{V} .1945$, H. Hoogstraal leg. (ZMAU).

DESCRIPTION. Male. Dark brown. Trochanters and proximal halves of femurs testaceous.

Head dorsally with conspicuous roundish impression behind antennal prominence, antennal sockets almost contiguous. Eyes large (separated medially above by about 0.9 times their radius). Ultimate maxillary palpomere small, only slightly longer than wide, widest at middle. Antennae extending to just elytral two thirds; from antennomere 3 flattened, serrate, antennomere 3 about 3.6 times longer than antennomere 2 and subequal in length to antennomere 4 ; antennomeres 3-11 with long erect pubescence.

Pronotum transverse, 1.5 times wider than long, with almost straight sides, pronounced anterior and prominent acute posterior angles, anterior margin triangularly produced forward (Fig. 105). Scutellum square, slightly emarginate at apex.

Elytra long (3.2 times as long as wide humerally), parallel-sided, with four almost equally developed primary costae; interstices with double rows of subquadrate cells. Pubescence uniform, short and decumbent.

Aedeagus with relatively robust median lobe, conspicuously flattened in lateral view at apex (Figs 106-107).

Length: $4.4 \mathrm{~mm}$. Width (humerally): $1.1 \mathrm{~mm}$.

Female. Unknown.

ETYMOLOGY. The new species is named after Dr. B. Brugge (Zoological Museum of Amsterdam University), who helped with the loan of the ample Lycidae material from the Sunda Islands and New Guinea.

DIAGNOSIS. $P$. bruggei sp.n. is probably related to $P$. serratus (Bocáková, 1997), easily distinguishable by the uniformly black elytra and male genital structures (Figs 106-107).

\section{Plateros grootaerti Kazantsev sp.n.} Figs 108-110

MATERIAL: Holotype, $\sigma^{\top}$, Papua New Guinea, Madang Province, Baiteta, light AR 8 (canopy mission), 11.VI.1996, O. Missa leg. (IRSN); paratype, $O^{7}$, Papua New Guinea, Madang Province, Baiteta, light (canopy mission), IV.1996, O. Missa leg. (ICCM).

DESCRIPTION. Male. Dark brown. Pronotum, scutellum, elytra outer margins, pro-, meso- and metathorax, coxae, trochanters, femurs, tibiae and tarsomeres 1 proximally testaceous.

Head dorsally with conspicuous roundish impression behind antennal prominence, antennal sockets almost contiguous. Eyes moderately large (separated medially above by about 1.2 times their radius). Ultimate maxillary palpomere relatively small, elongate, widest at middle. Antennae extending to elytral two thirds; from antennomere 3 flattened, serrate, antennomere 3 about 3 times longer than antennomere 2 and 1.5 times shorter than antennomere 4; antennomeres 3-11 with moderately long erect pubescence.

Pronotum transverse, 1.2 times wider than long, with straight sides, rounded anterior and straight posterior angles, anterior margin conspicuously produced forward, posterior margin medially slightly produced backward (Fig. 108). Scutellum square, feebly emarginate at apex.
Elytra long (3.6 times as long as wide humerally), parallel-sided, with swollen outer margins, four almost equally developed primary costae; interstices with double rows of small roundish cells. Pubescence short and decumbent.

Aedeagus with straight widened in the middle median lobe, provided with distal pair of dents (Figs 108-110).

Length: $5.5-6.0 \mathrm{~mm}$. Width (humerally): $1.3-1.4 \mathrm{~mm}$.

Female. Unknown.

ETYMOLOGY. The new species is named after Dr. P. Grootaert (Institut Royal de Sciences naturelles de Belgique, Bruxelles), who kindly arranged the loan of the vast Lycidae material from New Guinea.

DIAGNOSIS. $P$. grootaerti sp.n. is possibly related to $P$. serratus (Bocáková, 1997), easily distinguishable by the black elytra with pale margins and orange testaceous pronotum, as well as by the male genital structures (Figs 108-110).

\section{Plateros holynskiorom Kazantsev sp.n.} Figs 111-113

MATERIAL: Holotype, $\sigma^{7}$, Papua New Guinea, $10 \mathrm{~km} \mathrm{~N}$ Madang, 2 km NNW Riwo, 8-11.II.1989, M. \& R. Holyñski leg. (ICCM).

DESCRIPTION. Male. Dark brown. Elytral margins light brown; pedicel distally, outer margin of antennomeres 3-11, pronotum, scutellum, trochanters and femurs proximally testaceous.

Head dorsally with conspicuous triangular impression behind antennal prominence, antennal sockets almost contiguous. Eyes large (separated medially above by about their radius). Ultimate maxillary palpomere small, elongate, parallel-sided, convex at apex. Antennae narrow, slightly tapering distally, extending to elytral four fifths; from antennomere 3 flattened, serrate, antennomere 3 about 3 times longer than antennomere 2 and 1.3 times shorter than antennomere 4; antennomeres 3-11 with long erect curly pubescence.

Pronotum transverse, 1.7 times wider than long, trapezoidal, with obscured anterior and acute prominent posterior angles, anterior margin triangularly produced forward, posterior margin somewhat concave (Fig. 111). Scutellum square, slightly rounded and emarginate at apex.

Elytra long (3.1 times as long as wide humerally), parallel-sided, with four equally developed primary costae; interstices with double rows of roundish cells. Pubescence uniform, short and decumbent.

Aedeagus with relatively straight, slightly bent and narrowed distally median lobe (Figs 112-113).

Length: $6.2 \mathrm{~mm}$. Width (humerally): $1.7 \mathrm{~mm}$.

Female. Unknown.

ETYMOLOGY. The new species is named after Dr. R. Holyñski and his wife, M. Holyñska, who collected the unique type specimen.

DIAGNOSIS. P. holynskiorom sp.n. is somewhat similar to P. inflexus (Bocáková, 1997), easily distinguishable by the black elytra and orange testaceous pronotum and scutellum, as well as by the male genital structures (Figs 112-113).

\section{Plateros indentatus Kazantsev sp.n. Figs 114-116}

MATERIAL: Holotype, ऽ $\bigcirc^{\top}$, Papua New Guinea, Madang Province, Baiteta, AR 22 (canopy mission), 12.VI.1996, O. Missa leg. (IRSN).

DESCRIPTION. Male. Black. Pedicel distally, basal palpomeres, trochanters and femurs proximally testaceous

Head dorsally with conspicuous roundish impression behind antennal prominence, antennal sockets almost contiguous. Eyes moderately large (separated medially above by about 1.3 times their radius). Ultimate maxillary palpomere 
small, elongate, widened near apex. Antennae narrow, extending to elytral three fourths; from antennomere 3 flattened, serrate, antennomere 3 about 3 times longer than antennomere 2 and 1.3 times shorter than antennomere 4; antennomeres 3-11 with long erect curly pubescence.

Pronotum transverse, 1.7 times wider than long, slightly trapezoidal, with blunt anterior and rounded posterior angles, anterior margin relatively little produced forward (Fig. 114). Scutellum square, feebly emarginate at apex.

Elytra long (3.4 times as long as wide humerally), parallel-sided, with primary costa 4 more elevated in proximal third; interstices with double rows of small, mostly pentagonal cells. Pubescence uniform, short and su-erect.

Aedeagus with narrow and slightly bent distally median lobe (Figs 115-116).

Length: $4.0 \mathrm{~mm}$. Width (humerally): $0.9 \mathrm{~mm}$.

Female. Unknown.

ETYMOLOGY. The name of the new species is derived from the Latin for "teethless", alluding to the shape of its aedeagus.

DIAGNOSIS. $P$. indentatus sp.n. is similar to $P$. simplex (Bocáková, 1997), distinguishable by the narrower and more conspicuously bent distally median lobe of the aedeagus (Figs 115-116).

\section{Plateros madangensis Kazantsev sp.n.} Figs 117-119

MATERIAL: Holotype, $\sigma^{\top}$, Papua New Guinea, Madang Province, Baiteta, fogging, AR 47 (canopy mission), 30.IV.1996, O. Missa leg. (IRSN); paratype, + , Papua New Guinea, Madang Province, Baiteta, fogging, AR 39 (canopy mission), 4.VIII.1995, O. Missa leg. (ICCM).

DESCRIPTION. Male. Dark brown. Outer margin of antennomeres 3-11, palps, pronotum, trochanters and femurs proximally testaceous.

Head dorsally with conspicuous roundish impression behind antennal prominence, antennal sockets almost contiguous. Eyes large (their radius by 1.7 times exceeding distance separating them). Ultimate maxillary palpomere small, elongate, widest near apex. Antennae narrow, filiform, extending to elytral three fourths; antennomere 3 about 2.5 times longer than antennomere 2 and 1.4 times shorter than antennomere 4; antennomeres 3-11 with long erect curly pubescence.

Pronotum transverse, 1.5 times wider than long, with almost straight sides, blunt anterior and acute posterior angles, anterior margin triangularly produced forward; posterior margin somewhat concave (Fig. 117). Scutellum square, noticeably emarginate at apex.

Elytra long (3.3 times as long as wide humerally), parallel-sided, with four equally developed primary costae; interstices with double rows of roundish cells. Pubescence uniform, short and decumbent.

Aedeagus with slightly bent and hooked distally median lobe, bidentate near apex (Figs 118-119).

Female. Similar to male, but eyes smaller.

Length: 4.6-5.6 mm. Width (humerally): 1.1-1.3 $\mathrm{mm}$.

ETYMOLOGY. The name of the new species is derived from the province in northwest Papua New Guinea, where the type series was collected.

DIAGNOSIS. P. madangensis sp.n. is similar to $P$. proprius (Bocáková, 1997), distinguishable by the larger eyes and differently shaped male genital structures (Figs 118-119).

\section{Plateros makarovi Kazantsev sp.n.} Figs 120-122

MATERIAL: Holotype, $\sigma^{\top}$, Papua New Guinea, Madang Province, Baiteta, light, AR 52 (canopy mission), 23.V.1996, O. Missa leg. (IRSN)
DESCRIPTION. Male. Black. Pedicel distally light brown; trochanters and femurs proximally testaceous.

Head dorsally with conspicuous roundish impression behind antennal prominence, antennal sockets almost contiguous. Eyes moderately large (separated medially above by about their radius). Ultimate maxillary palpomere small, only slightly longer than wide, nearly parallel-sided. Antennae extending to elytral three fourths; from antennomere 3 flattened, serrate, antennomere 3 about 2.5 times longer than antennomere 2 and 1.2 times shorter than antennomere 4; antennomeres 3-11 with long erect pubescence.

Pronotum transverse, 1.4 times wider than long, trapezoidal, with noticeable anterior and acute prominent posterior angles, anterior margin triangularly produced forward (Fig. 120). Scutellum square, slightly emarginate at apex.

Elytra long (3.2 times as long as wide humerally), parallel-sided, with primary costa 4 more developed in proximal third; interstices with double rows of subquadrate cells. Pubescence uniform, short and decumbent.

Aedeagus with hooked distally median lobe, provided with curved distal tooth (Figs 121-122).

Length: $4.5 \mathrm{~mm}$. Width (humerally): $1.1 \mathrm{~mm}$.

Female. Unknown.

ETYMOLOGY. The new species is named after Dr. K. Makarov, who kindly helped with the photographs for this paper.

DIAGNOSIS. P. makarovi sp.n. is possibly related to $P$. serratus (Bocáková, 1997), distinguishable by the uniformly black elytra, as well as by the male genital structures (Figs 121-122).

\section{Plateros novaguineensis Kazantsev sp.n.} Figs 123-124

MATERIAL: Holotype, $\sigma^{\top}$, Papua New Guinea, Madang Province, Baiteta, light, AR 52 (canopy mission), 20.V.1996, O. Missa leg. (IRSN)

DESCRIPTION. Male. Dark brown. Pedicel distally and outer elytral margins light brown; frons, labrum, palps, pronotum, scutellum, pro-meso- and metathorax, coxae, trochanters, femurs, except distal tips, and tibiae proximally testaceous.

Head dorsally with inconspicuous roundish impression behind antennal prominence, antennal sockets almost contiguous. Eyes moderately large (separated medially above by about their radius). Ultimate maxillary palpomere small, elongate, parallel-sided, convex at apex. Antennae extending to elytral five sixths; from antennomere 3 flattened, serrate, antennomere 33 times longer than antennomere 2 and 1.5 times shorter than antennomere 4; antennomeres 3-11 with short erect pubescence and longer distal bristles.

Pronotum transverse, 1.2 times wider than long, with almost straight sides, blunt anterior and acute posterior angles, anterior margin rounded (Fig. 123). Scutellum subquadrate, minutely emarginate at apex.

Elytra long (3.6 times as long as wide humerally), parallel-sided, with four equally developed primary costae; interstices with double rows of roundish or pentagonal cells. Pubescence uniform, short and decumbent.

Aedeagus with straight median lobe with hammer-like dilatation at apex (Fig. 124).

Length: $5.7 \mathrm{~mm}$. Width (humerally): $1.3 \mathrm{~mm}$.

Female. Unknown.

ETYMOLOGY. The name of the new species is derived from the country, where the unique type specimen was collected.

DIAGNOSIS. $P$. novaguineensis sp.n. is related to $P$. languidulus (Bocáková, 1997), distinguishable by the rufous elytral margins and differently shaped male genital structures (Fig. 124). 


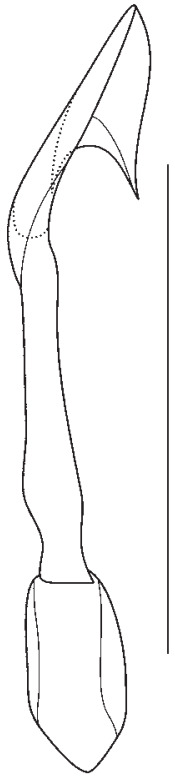

118

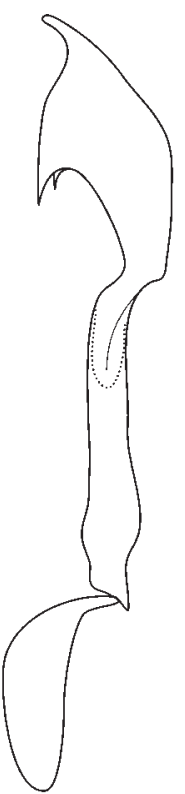

119

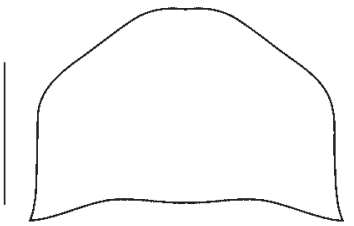

117

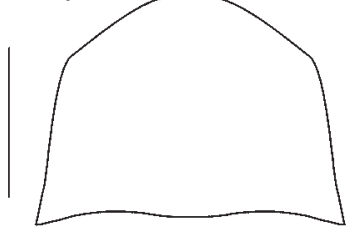

120

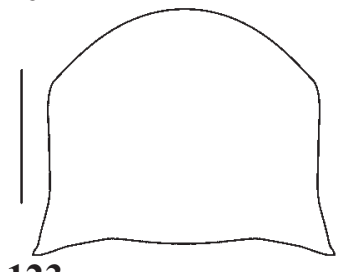

123
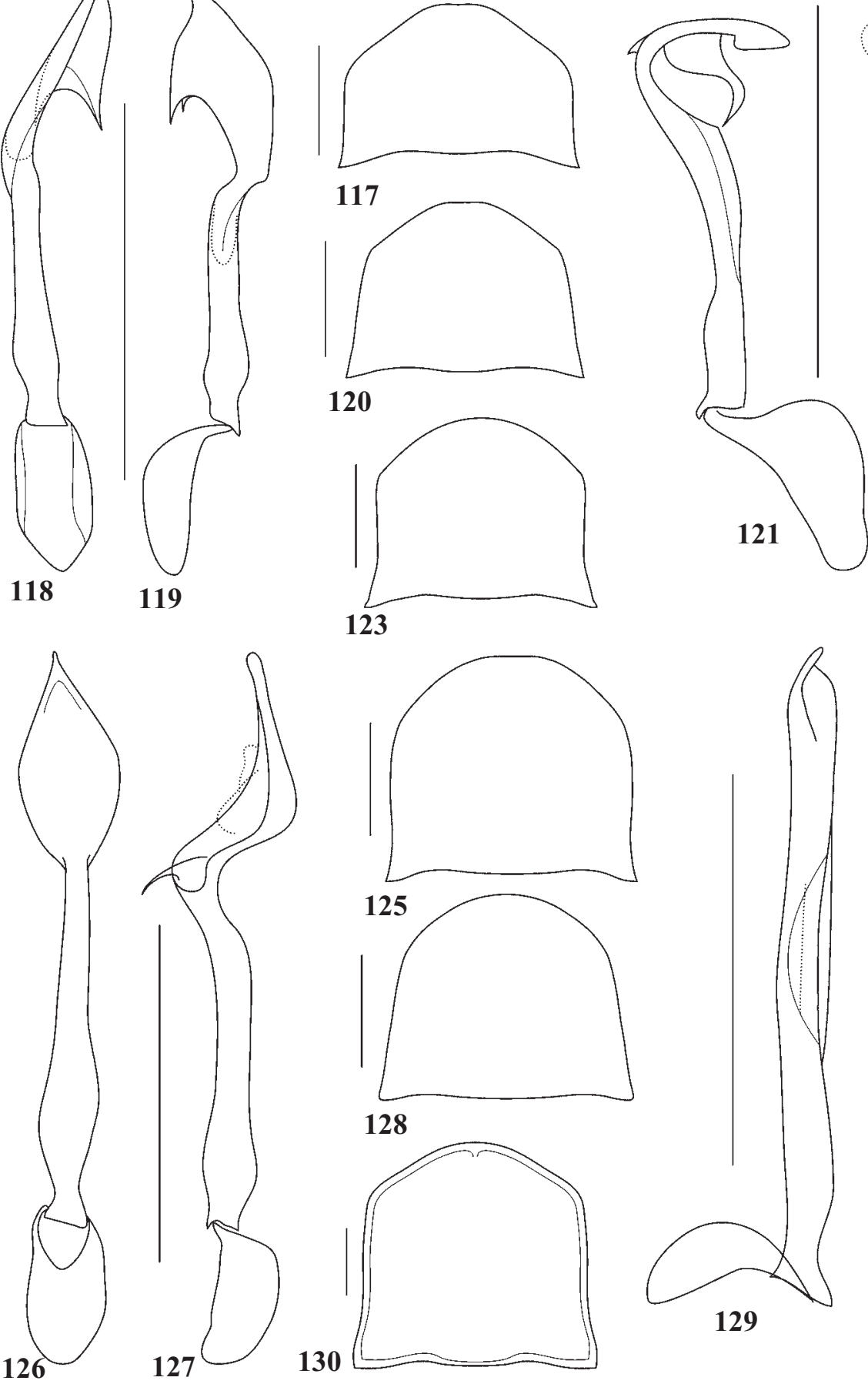

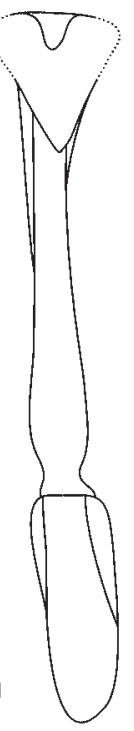

122

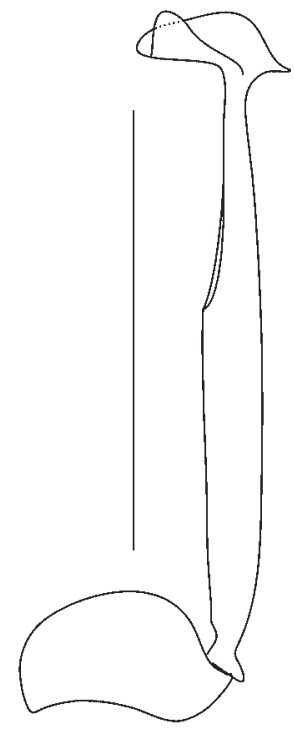

124

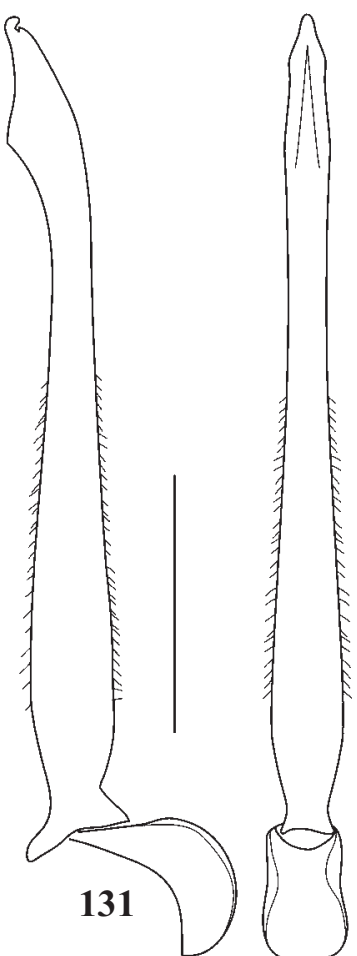

132

Figs 117-132. Details of Plateros spp., holotypes males: 117-119 - P. madangensis sp.n.; 120-122 - P. makarovi sp.n.; 123-124 - P. novaguineensis sp.n.; 125-127 - P. papuaensis sp.n.; 128-129 - P. rufosuturalis sp.n.; 130-132 - P. villosopenis sp.n.; 117 , 120, 123, 125, 128, 130 - pronotum; 118-119, 121-122, 124, 126-127, 129, 131-132 — aedeagus. Scale bar: $5 \mathrm{~mm}$.

Рис. 117-132. Детали строения Plateros spp., голотипы, самцы: 117-119 - P. madangensis sp.n.; 120-122 — P. makarovi sp.n.; 123124 - P. novaguineensis sp.n.; 125-127 - P. papuaensis sp.n.; 128-129 - P. rufosuturalis sp.n.; 130-132 - P. villosopenis sp.n.; 117, 120, 123, 125, 128, 130 - переднеспинка; 118-119, 121-122, 124, 126-127, 129, 131-132 — эдеагус. Масштабная линейка: 5 мм.

\section{Plateros papuaensis Kazantsev sp.n.}

Figs 125-127

MATERIAL: Holotype, $\sigma^{7}$, Papua New Guinea, $10 \mathrm{~km}$ N Madang, 2 km NNW Riwo, 8-11.II.1989, M. \& R. Holyñski leg. (ICCM).
DESCRIPTION. Male. Dark brown. Pedicel distally and outer elytral margins in proximal half light brown; labrum, palps, pronotum, scutellum, coxae, trochanters, femurs in proximal half, tibiae proximally and tarsomeres 1-2 testaceous. 
Head dorsally with inconspicuous triangular impression behind antennal prominence, antennal sockets almost contiguous. Eyes moderately large (separated medially above by about their radius). Ultimate maxillary palpomere small, elongate, parallel-sided, convex at apex. Antennae extending to elytral three fourths; from antennomere 3 flattened, serrate, antennomere 3 about 2.4 times longer than antennomere 2 and 1.3 times shorter than antennomere 4 ; antennomeres 3 11 with relatively long erect pubescence.

Pronotum transverse, 1.2 times wider than long, with widened anteriorly sides, blunt anterior and small acute prominent posterior angles (Fig. 125). Scutellum square, truncate at apex.

Elytra long (3.8 times as long as wide humerally), narrow, flattened, parallel-sided, with four equally developed primary costae; interstices with double rows of roundish or pentagonal cells. Pubescence uniform, short and decumbent.

Aedeagus with conspicuously dilated distally median lobe, provided with long spine at base of dilatation (Figs 126-127).

Length: $5.8 \mathrm{~mm}$. Width (humerally): $1.2 \mathrm{~mm}$.

Female. Unknown.

ETYMOLOGY. The name of the new species is derived from the country, where the unique type specimen was collected.

DIAGNOSIS. P. papuaensis sp.n. is possibly related to P. usitatus (Bocáková, 1997), but differs by the more dilated distally median lobe, with a long spine at the base of the dilatation (Figs 126-127).

\section{Plateros rufosuturalis Kazantsev sp.n.}

Figs 128-129

MATERIAL: Holotype, $0^{7}$, Papua New Guinea, $38 \mathrm{~km} \mathrm{~N}$ Madang, 3 km NW Matukar, 27.I.1989, M. \& R. Holyñski leg. (ICCM).

DESCRIPTION. Male. Dark brown. Pedicel distally, labrum, palps, pronotum, scutellum, outer elytral margins and suture in proximal three fourths, pro-meso- and metathorax, coxae, trochanters, femurs and tibiae, except distal tips, and tarsomeres 1 testaceous.

Head dorsally with inconspicuous rectangular impression behind antennal prominence, antennal sockets almost contiguous. Eyes relatively small (separated medially above by about 2 times their radius). Ultimate maxillary palpomere small, elongate, widening and convex distally. Antennae extending to elytral four fifths; from antennomere 3 flattened, but nearly parallel-sided, antennomere 3 about 2.4 times longer than antennomere 2 and 1.3 times shorter than antennomere 4; antennomeres 3-11 with short erect pubescence.

Pronotum transverse, 1.3 times wider than long, trapezoidal, with rounded anterior and acute posterior angles, anterior margin rounded (Fig. 128). Scutellum square, rounded and minutely emarginate at apex.

Elytra long (3.3 times as long as wide humerally), parallel-sided, with conspicuously swollen outer margins and four equally developed primary costae; interstices with double rows of small roundish cells. Pubescence uniform, short and decumbent.

Aedeagus with straight median lobe, provided with cavity in central portion and bifid at apex (Fig. 129).

Length: $5.6 \mathrm{~mm}$. Width (humerally): $1.3 \mathrm{~mm}$

Female. Unknown.

ETYMOLOGY. The name of the new species is derived from the Latin for "red" and "suture", alluding to the coloration of the new species.

DIAGNOSIS. By the structure of the aedeagus $P$. rufosuturalis sp.n. resembles $P$. nigrithorax Pic, 1935 from Zaire, illustrated by Kazantsev [2000], but is easily distinguishable by the swollen rufous elytral margins and slenderer median lobe of the aedeagus (Fig. 129).

\section{Plateros villosopenis Kazantsev sp.n.}

Figs 130-132

MATERIAL: Holotype, $\sigma^{\top}$, Papua New Guinea, Madang Province, Baiteta, AR 10 (canopy mission), 20.V.1996, O. Missa leg. (IRSN); paratypes: $\sigma^{7}$, same label; $\sigma^{7}$, Papua New Guinea, Madang Province, Baiteta, light trap AR 14 (canopy mission), 4.VI.1996, O. Missa leg.; $60^{\top} \sigma^{7}$ and + , Papua New Guinea, Madang Province, Baiteta, light T 2 (canopy mission), 20.VI.1996, O. Missa leg.; 우, Papua New Guinea, Madang Province, Baiteta, light AR 62 (canopy mission), 4.VII.1996, O. Missa leg. (IRSN and ICCM).

DESCRIPTION. Male. Testaceous. Inner margin of antennomeres 3-10 brown.

Head dorsally with inconspicuous trapezoidal impression behind antennal prominence, antennal sockets almost contiguous. Eyes moderately large (separated medially above by about 1.2 times their radius). Ultimate maxillary palpomere relatively small, elongate, widest near base. Antennae relatively broad, tapering distally, extending to elytral three fourths; from antennomere 3 flattened, serrate, antennomere 3 about 2.8 times longer than antennomere 2 and 1.2 times shorter than antennomere 4; antennomeres 3-11 with short erect pubescence and longer distal bristles.

Pronotum almost quadrate, only 1.1 times wider than long, with narrow swollen margins, almost straight sides, blunt anterior and small acute posterior angles, anterior margin triangularly produced forward (Fig. 130). Scutellum square, slightly emarginate at apex.

Elytra long (3.75 times as long as wide humerally), parallel-sided, with four equally developed primary costae; interstices with double rows of small roundish cells. Pubescence uniform, short and decumbent.

Aedeagus with straight median lobe, provided with minute hook at apex and numerous bristles in proximal two thirds (Figs 131-132).

Female. Similar to male, but eyes smaller and antennomeres 3-10 less serrate.

Length: $8.6-11.4 \mathrm{~mm}$. Width (humerally): $2.0-2.5 \mathrm{~mm}$.

ETYMOLOGY. The name of the new species is derived from the Latin for "hairy" and "penis", alluding to the unusually hairy median lobe of its aedeagus.

DIAGNOSIS. P. villosopenis sp.n. is very unlike the rest of Plateros from New Guinea due to its mostly testaceous coloration; also, it may be differentiated from all known congenerics by the conspicuously hairy proximal part of the median lobe of the aedeagus (Figs 131-132).

\section{Plateros cacaophilus Kazantsev sp.n. Figs 133-134}

MATERIAL: Holotype, $0^{7}$, Costa Rica, Guanacaste, Vulcan Cacao, SW slopes, 1000-1400 m, 5-10.IV.2004, M. Fedoruk leg. (ICCM); paratypes: $20^{7} O^{7}$, same label (ICCM).

DESCRIPTION. Male. Dark brown. Pronotum pink, with pair of basal dark spots.

Head dorsally with conspicuous elongate impression behind antennal prominence, antennal sockets almost contiguous. Eyes large (separated medially above by about 0.8 times their radius). Ultimate maxillary palpomere relatively small, only slightly longer than wide, widening distally. Antennae relatively narrow, extending to elytral two thirds; from antennomere 3 flattened, serrate, antennomere 3 about twice as long as antennomere 2 and 2.2 times shorter than antennomere 4; antennomeres 3-11 with short erect pubescence and longer distal bristles. 
Pronotum strongly transverse, 1.7 times wider than long, trapezoidal, with pronounced anterior and long acute posterior angles, anterior margin triangularly produced forward (Fig. 133). Scutellum elongate, parallel-sided, feebly emarginate at apex.

Elytra long (3.5 times as long as wide humerally), elliptical, widest ca. in middle, with four equally developed primary costae; interstices with double rows of subquadrate cells. Pubescence uniform, short and decumbent.

Aedeagus with slightly bent and conspicuously widened distally median lobe (Fig. 134).

Length: 5.8-6.2 mm. Width (humerally): $1.4-1.5 \mathrm{~mm}$.

Female. Unknown.

ETYMOLOGY. The name of the new species is derived from the volcano, on the slopes of which the type series was collected.

DIAGNOSIS. P. cacaophilus sp.n. does not resemble any of the Plateros species of the area due to its strongly transverse pink pronotum with long posterior angles (Fig. 133).

\section{Plateros cerberus Kazantsev sp.n.} Figs 135-137

MATERIAL: Holotype, $\sigma^{7}$, Costa Rica, Vulcan Poas, 1900 2200 m, 7-12.IV.2003, S. Kazantsev leg. (ICCM); paratypes: and + , same label (ICCM).

DESCRIPTION. Male. Dark brown. Pronotal lateral margins and humeri testaceous.

Head dorsally with small inconspicuous roundish impression behind antennal prominence, antennal sockets separated by minute lamina. Eyes small (separated medially above by about 3.6 times their radius). Ultimate maxillary palpomere relatively small, only slightly longer than wide, widening and convex distally. Antennae relatively broad, tapering distally, extending to elytral two thirds; from antennomere 3 flattened, serrate, antennomere 3 about twice as long as antennomere 2 and 1.8 times shorter than antennomere 4; antennomeres 3-11 with short erect pubescence and longer distal bristles.

Pronotum transverse, 1.4 times wider than long, trapezoidal, with rounded anterior angles and small acute posterior angles, anterior margin rounded (Fig. 135). Scutellum square, truncate at apex.

Elytra long (4 times as long as wide humerally), widest in distal fourth, with four equally developed prominent primary costae; interstices with double rows of subquadrate cells. Pubescence uniform, sort and decumbent.

Aedeagus with almost straight slender median lobe, provided with two small perpendicular teeth near apex (Figs 136-137).

Female. Similar to male, but antennae slightly shorter and narrower.

Length: $6.8-9.3 \mathrm{~mm}$. Width (humerally): $1.5-2.0 \mathrm{~mm}$.

ETYMOLOGY. The name of the new species is derived from the Latin noun meaning "dog guarding Hades", alluding to its dark coloration.

DIAGNOSIS. P. cerberus sp.n. resembles $P$. terminator Kazantsev, 2005 [= terminalis Gorham, 1880, homonym] due to the similar coloration pattern, but differs by the uniformly black antennae and testaceous spot on shoulders, as well as by the male genital structures (Figs 136-137).

\section{Plateros nigripennis Kazantsev sp.n.} Figs 138-140

MATERIAL: Holotype, $\sigma^{7}$, Costa Rica, Monteverde, 1500 1800 m, 15-20.IV.2003, S. Kazantsev leg. (ICCM); paratypes, $0^{7}$ and + , same label (ICCM).
DESCRIPTION. Male. Dark brown. Pronotal lateral margins testaceous.

Head dorsally with small, but conspicuous round impression behind antennal prominence, antennal sockets almost contiguous. Eyes relatively small (separated medially above by about 2.4 times their radius). Ultimate maxillary palpomere small, slightly longer than wide, widening and convex distally. Antennae narrow, tapering distally, extending to elytral two thirds; from antennomere 3 flattened, serrate, antennomere 3 about 1.2 longer than antennomere 2 and 2.3 times shorter than antennomere 4; antennomeres 3-11 with short semi-erect pubescence and longer distal bristles.

Pronotum transverse, 1.4 times wider than long, trapezoidal, with conspicuous anterior and acute posterior angles, anterior margin triangularly produced forward (Fig. 138). Scutellum elongate, parallel-sided, feebly emarginate at apex.

Elytra long (4 times as long as wide humerally), parallelsided, with four equally developed prominent primary costae; interstices with double rows of subquadrate cells. Pubescence uniform, short and decumbent.

Aedeagus with short, widened and hooked distally median lobe (Figs 138-140).

Female. Similar to male, but slightly more robust, eyes smaller, antennae somewhat shorter.

Length: $6.5-6.7 \mathrm{~mm}$. Width (humerally): $1.45-1.55 \mathrm{~mm}$.

ETYMOLOGY. The name of the new species is derived from the Latin for "black" and "wings", alluding to its uniformly black elytra.

DIAGNOSIS. $P$. nigripennis sp.n. is rather close to $P$. cerberus sp.n., distinguishable by the uniformly black parallel-sided elytra, short pedicel and short, widened and hooked distally median lobe of the aedeagus (Figs 138-140).

\section{Plateros papilio Kazantsev sp.n.} Figs 141-142

MATERIAL: Holotype, $O^{7}$, Costa Rica, Puntarenas, $2 \mathrm{~km}$ NE Golfito, 2-3.VII.1997, at blacklight, J. Scott leg. (ICCM).

DESCRIPTION. Male. Dark brown. Labrum, pronotum, except for pair of basal median longitudinal stripes, scutellum, elytra, except longitudinal stripe in proximal half in first interstice, trochanters and femurs distally testaceous.

Head dorsally with two minute round impressions behind antennal prominence, antennal sockets separate by minute lamina. Eyes moderately large (separated medially above by about 1.3 times their radius). Ultimate maxillary palpomere small, elongate, slightly widening distally. Antennae broad, tapering distally, extending to elytral two thirds; from antennomere 3 flattened, serrate, antennomere 3 about 3 times longer than antennomere 2 and 1.3 times shorter than antennomere 4; antennomeres 3-11 with short erect pubescence and longer distal bristles.

Pronotum transverse, 1.5 times wider than long, trapezoidal, with conspicuous anterior and acute posteriorly produced posterior angles, posterior margin conspicuously bisinuate (Fig. 141). Scutellum square, truncate at apex.

Elytra long ( 3 times as long as wide humerally), flattened, parallel-sided, with primary costae 2 and 4 more developed in most of their length; interstices with double rows of small transverse cells. Pubescence uniform, short and decumbent.

Aedeagus with relatively robust median lobe, provided with butterfly-like apical structure (Fig. 142).

Length: $7.8 \mathrm{~mm}$. Width (humerally): $2.2 \mathrm{~mm}$.

Female. Unknown.

ETYMOLOGY. The name of the new species is derived from the Latin noun meaning "butterfly", alluding to the shape of the apex of its aedeagus resembling a sitting butterfly in lateral view. 

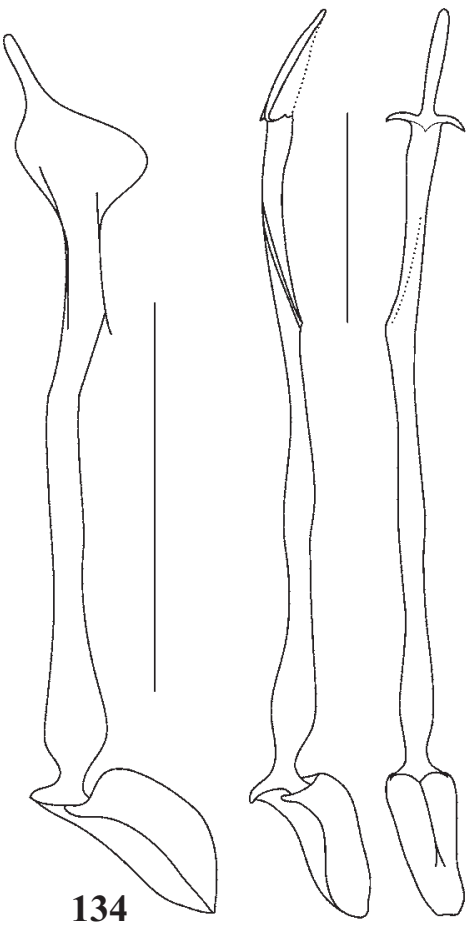

136

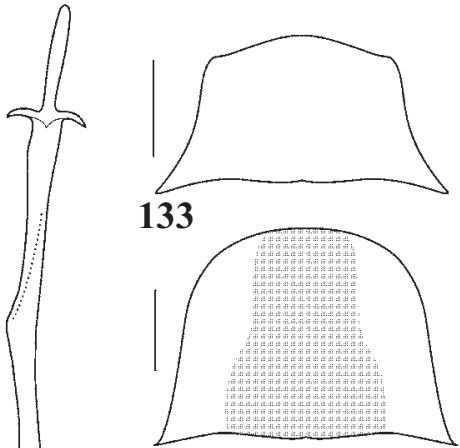

135

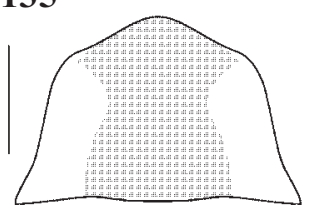

138

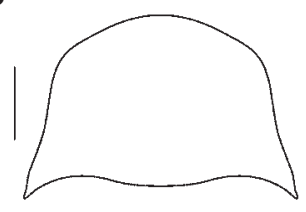

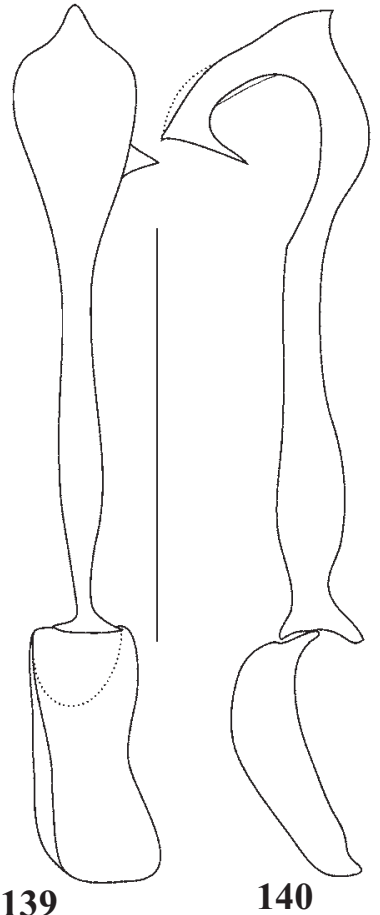

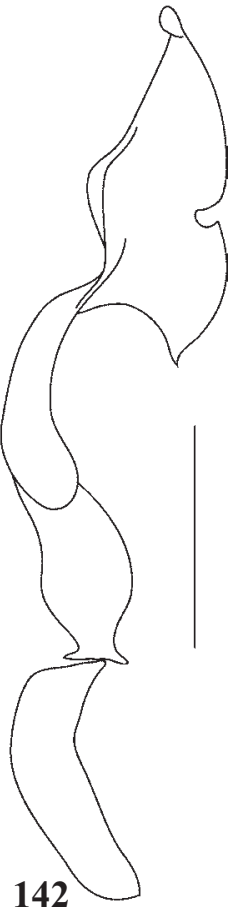

141

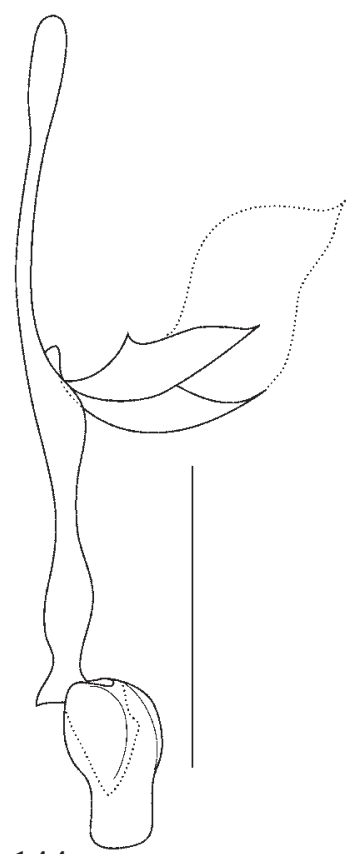

144

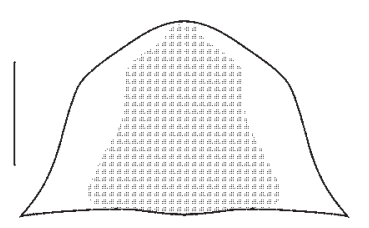

143

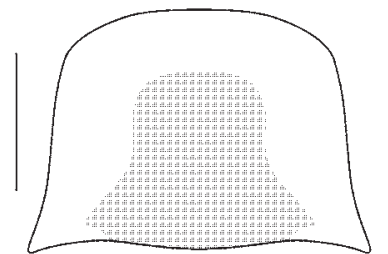

145

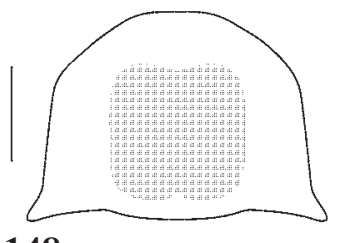

148

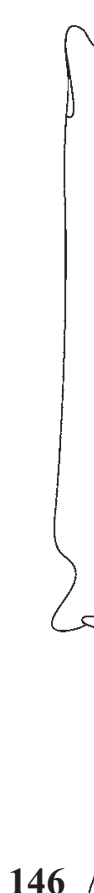

146
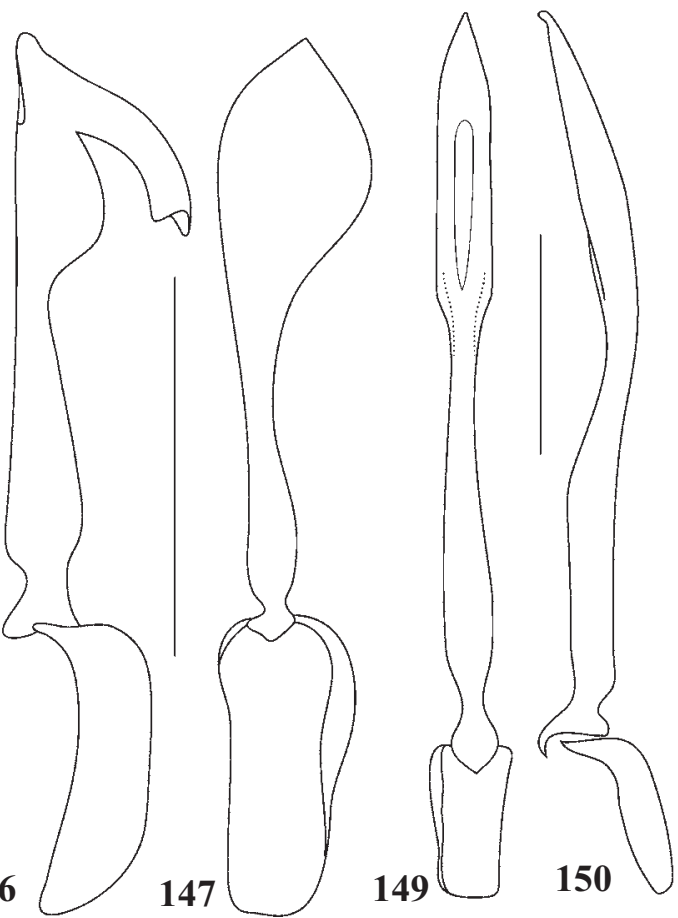

Figs 133-150. Details of Plateros spp., holotypes males: 133-134 - P. cacaophilus sp.n.; 135-137 - P. cerberus sp.n.; $138-140-P$. nigripennis sp.n.; 141-142 - P. papilio sp.n.; 143-144 - P. parallelipennis sp.n.; 145-147 — P. hephaestus sp.n.; 148-150-P. amazonensis sp.n.; 133, 135, 138, 141, 143, 145, 148 — pronotum; 134, 136-137, 138-140, 142, 144, 146-147, 148-150 — aedeagus. Scale bar: $5 \mathrm{~mm}$.

Рис. 133-150. Детали строения Plateros spp., голотипы, самцы: 133-134 - P. cacaophilus sp.n.; 135-137 — P. cerberus sp.n.; 138140 - P. nigripennis sp.n.; 141-142 — P. papilio sp.n.; 143-144 - P. parallelipennis sp.n.; 145-147 — P. hephaestus sp.n.; 148-150P. amazonensis sp.n.; 133, 135, 138, 141, 143, 145, 148 - переднеспинка; 134, 136-137, 138-140, 142, 144, 146-147, 148-150 эдеагус. Масштабная линейка: 5 мм.

DIAGNOSIS. P. papilio sp.n. does not resemble any of the Plateros species of the area due to its testaceous elytra with dark longitudinal stripe in the first interstice, as well as by the robust median lobe of the aedeagus, provided with butterfly-like apical structure (Fig. 142). 


\section{Plateros parallelipennis Kazantsev sp.n.} Figs 143-144

MATERIAL: Holotype, $\sigma^{7}$, Costa Rica, Monteverde, 15001800 m, 15-20.IV.2003, S. Kazantsev leg. (ICCM); paratypes, $0^{7}$ and + , same label; $O^{7}$, Costa Rica, Vulcan Poas, 1900-2200 m, 712.IV.2003, S. Kazantsev leg. (ICCM).

DESCRIPTION. Male. Black. Proximal palpomeres, pronotal lateral margins, trochanters and profemurs testaceous.

Head dorsally with conspicuous and deep round impression behind antennal prominence, antennal sockets almost contiguous. Eyes large (separated medially above by about their radius). Ultimate maxillary palpomere small, elongate, nearly parallel-sided, feebly convex at apex. Antennae broad, tapering distally, extending to elytral four fifths; from antennomere 3 flattened, serrate, antennomere 3 about 4 times longer than antennomere 2 and 1.25 times shorter than antennomere 4; antennomeres 3-11 with long erect pubescence.

Pronotum transverse, 1.6 times wider than long, trapezoidal, with conspicuous anterior and long acute posterior angles, anterior margin triangularly produced forward (Fig. 143). Scutellum elongate, parallel-sided, truncate at apex.

Elytra long (3.9 times as long as wide humerally), parallel-sided, with four almost equally developed primary costae; interstices with double rows of small roundish cells. Pubescence uniform, short and decumbent.

Aedeagus with slender median lobe, provided with two dragon wing-like appendages just below middle; phallobase partly closed dorsally as well (Fig. 144).

Female. Similar to male, but eyes smaller, antennae conspicuously shorter and less serrate, elytra slightly widened in distal half.

Length: $6.6-8.2 \mathrm{~mm}$. Width (humerally): $1.4-1.8 \mathrm{~mm}$.

ETYMOLOGY. The name of the new species is derived from the Latin for "parallel" and "wings", alluding to its parallel-sided elytra.

DIAGNOSIS. $P$. parallelipennis sp.n. is similar to $P$. nigripennis sp.n., distinguishable by the much slenderer and longer median lobe of the aedeagus, provided with two dragon wing-like appendages just below middle (Fig. 144); its partly closed dorsally phallobase seems to be quite unique, however, the typical Plateros female genitals assuredly brings the taxon to this very genus.

\section{Plateros hephaestus Kazantsev sp.n. Figs 145-147}

MATERIAL: Holotype, $0^{7}$, Costa Rica, Vulcan Poas, 2300 2400 m, 7-12.IV.2003, S. Kazantsev leg. (ICCM); paratypes: 3 우, same label; 2 우으, Costa Rica, Vulcan Poas, 1900-2200 m, 712.IV.2003, S. Kazantsev leg. (ICCM).

DESCRIPTION. Male. Black. Pronotal anterior and lateral margins testaceous.

Head dorsally with conspicuous deep round impression behind antennal prominence, antennal sockets separated by narrow lamina. Eyes small (separated medially above by about 4.4 times their radius). Ultimate maxillary palpomere small, elongate, widening and convex distally. Antennae narrow, almost filiform, extending to elytral two thirds; antennomere 3 about 1.1 times longer than antennomere 2 and 2 times shorter than antennomere 4 ; antennomeres 3-11 with short erect pubescence and longer distal bristles.

Pronotum transverse, 1.4 times wider than long, with almost straight sides, rounded anterior and small acute posterior angles, anterior margin relatively little produced forward (Fig. 145). Scutellum square, truncate at apex.

Elytra long (4.3 times as long as wide humerally), parallel-sided, with four prominent equally developed primary costae; interstices with double rows of roundish or pentagonal cells. Pubescence uniform, short and decumbent.

Aedeagus with short median lobe, its apical part straight, dilated at base of apical hook (Figs 146-147).

Female. Similar to male, but more robust, antennae shorter, with decumbent pubescence.

Length: 6.6-8.4 mm. Width (humerally): $1.4-1.9 \mathrm{~mm}$.

ETYMOLOGY. The name of the new species is derived from "Hephaistos", the Greek god of fire and volcanoes, as all specimens of the type series were collected on the slopes of an active volcano in Costa Rica.

DIAGNOSIS. $P$. hephaestus sp.n. is fairly close to $P$. nigripennis sp.n., distinguishable by the testaceous anterior and lateral margins of the pronotum and almost straight pronotal sides, as well as by the shorter median lobe of the aedeagus, with straighter apical part and dilatation at the base of apical hook (Figs 146-147).

\section{Plateros amazonensis Kazantsev sp.n. Figs $148-150$}

MATERIAL: Holotype, $\sigma^{7}$, Peru, Loreto, R. Amazon, $68 \mathrm{~km}$ SW Iquitos (to Nauta), R. Itaya, at light, $4^{\circ} 11^{\prime} \mathrm{S} 73^{\circ} 26^{\prime} \mathrm{W}, 110 \mathrm{~m}$, 1.II.2006, A. Petrov leg. (ICCM).

DESCRIPTION. Male. Dark brown. Pedicel distally, pronotal margins, elytral shoulders, outer margins extending to three fifths and obscured narrow band at ca. three fifths, trochanters proximally and femurs proximally testaceous.

Head dorsally with two small round impression behind antennal prominence, antennal sockets separated by minute lamina. Eyes small (separated medially above by about 2.3 times their radius). Ultimate maxillary palpomere relatively small, elongate, parallel-sided, rounded at apex. Antennae extending to elytral three fourths; from antennomere 3 flattened, strongly serrate, antennomere 3 about thrice as long as antennomere 2 and 1.3 times shorter than antennomere 4; antennomeres 3-11 with short semi-erect pubescence and longer distal bristles.

Pronotum transverse, 1.4 times wider than long, with almost straight sides, noticeable anterior and small acute posterior angles (Fig. 148). Scutellum square, rounded at apex.

Elytra moderately long (2.75 times as long as wide humerally), parallel-sided, with four equally developed primary costae; interstices with double rows of small, mostly pentagonal cells. Pubescence uniform, short and decumbent.

Aedeagus with straight, slightly widened distally and feebly bent before apex median lobe (Figs 148-150).

Length: $6.7 \mathrm{~mm}$. Width (humerally): $1.9 \mathrm{~mm}$.

Female. Unknown.

ETYMOLOGY. The name of the new species is derived from the river, in the basin of which the unique type specimen was collected.

DIAGNOSIS. P. amazonensis sp.n. is possibly related to P. subhumeralis Pic, 1923 of similar coloration, differing by the uniformly black antennae and different male genital structures (Figs 148-150).

\section{Plateros lugubris Kazantsev sp.n.} Figs 151-152

MATERIAL: Holotype, $\sigma^{7}$, Ecuador, Orellana, Tiputini Biol. Stn, $0^{\circ} 39.5^{\prime} \mathrm{S} 76^{\circ} 26^{\prime} \mathrm{W}, 28$. VII-3.VIII.2008, A. Tishechkin leg. (ICCM).

DESCRIPTION. Male. Black. Pedicel distally, antennomeres 8-11 and pronotal anterior and lateral margins testaceous.

Head dorsally with conspicuous roundish impression behind antennal prominence, antennal sockets separated by minute lamina. Eyes small (separated medially above by about 2.7 times their radius). Ultimate maxillary palpomere 


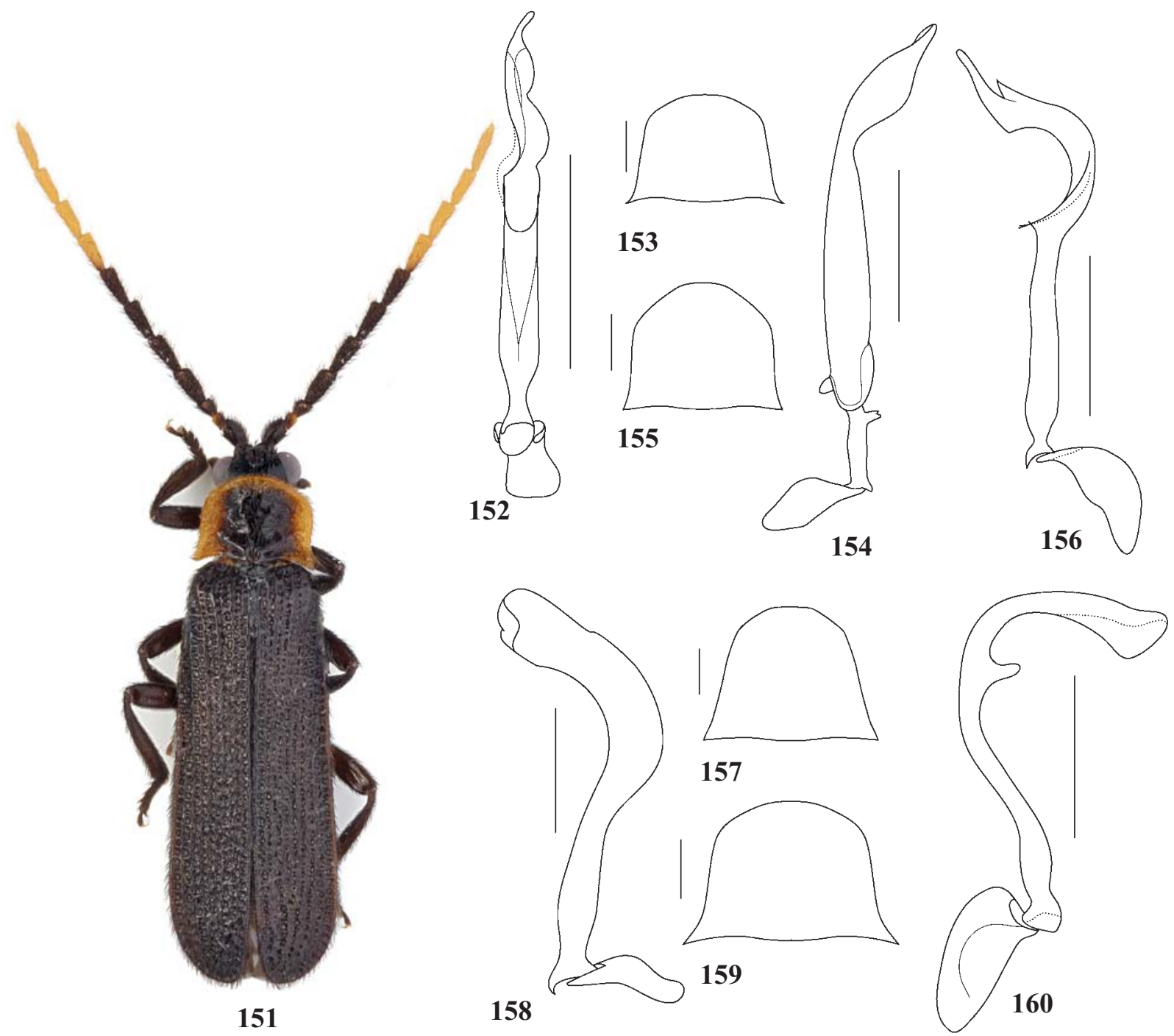

Figs 151-160. General view and details of Plateros spp., holotypes males: 151-152 - P. lugubris sp.n.; 153-154 - P. mosolovi sp.n.; 155-156 - P. nautaensis sp.n.; 157-158 - P. piger sp.n.; $158-160-P$. pirana sp.n.; 151 - general view $(1=5.0 \mathrm{~mm}) ; 153,155,157$, 159 — pronotum; 152, 154, 156, 158, 160 — aedeagus. Scale bar: $5 \mathrm{~mm}$.

Рис. 151-160. Общий вид и детали строения Plateros spp., голотипы, самцы: 151-152 — P. lugubris sp.n.; 153-154 — P. mosolovi sp.n.; 155-156 - P. nautaensis sp.n.; 157-158 - P. piger sp.n.; 158-160 — P. pirana sp.n.; 151 — общий вид $(1=5.0$ мм); 153, 155, 157, 159 — переднеспинка; 152, 154, 156, 158, 160 — эдеагус. Масштабная линейка: 5 мм.

small, only slightly longer than wide, widest at middle, convex at apex. Antennae narrow, extending to elytral two thirds; from antennomere 3 flattened, slightly serrate (Fig. 151), antennomere 3 about 1.4 times longer than antennomere 2 and 2.1 times shorter than antennomere 4 (Fig. 151); antennomeres 3-11 with short semi-erect pubescence.

Pronotum transverse, 1.4 times wider than long, with almost straight sides, rounded anterior and small acute posterior angles; anterior margin broadly rounded, posterior margin bisinuate (Fig. 151). Scutellum square, truncate at apex.

Elytra long (3.4 times as long as wide humerally), parallel-sided, with four equally developed and hardly distinguishable, except at proximal fourth, from secondary primary costae; interstices with double rows of small roundish (closer to outer margins) or irregular (closer to suture) cells. Pubescence uniform, short and decumbent.

Aedeagus with slender, almost straight, but slightly twisted and bent distally median lobe (Fig. 152).
Length: $5.0 \mathrm{~mm}$. Width (humerally): $1.2 \mathrm{~mm}$.

Female. Unknown

ETYMOLOGY. The name of the new species is derived from the Latin for "mourning", alluding to its black elytra.

DIAGNOSIS. P. lugubris sp.n. is somewhat similar to $P$. apicicornis Pic, 1923, easily distinguishable by the parallelsided elytra and four yellow terminal antennomeres, as well as by the male genital structures (Fig. 152).

\section{Plateros mosolovi Kazantsev sp.n.}

Figs 153-154

MATERIAL: Holotype, Peru, Huanuco, 40 km NNW Tingo Maria, Sta Marta, 1200 m, 15-16.IV.2008, O. Mosolov leg. (ICCM); paratypes: $2 O^{7} O^{7}$ and + , same label; $2 O^{7} O^{7}$, Peru, Amazon, $50 \mathrm{~km} \mathrm{~S}$ Iquitos, Panguana Camp, 28-30.I.1997, A. Petrov leg. (ICCM).

DESCRIPTION. Male. Black. Pronotal lateral margins and elytral shoulders testaceous.

Head dorsally with two small round impressions behind 
antennal prominence, antennal sockets almost contiguous. Eyes relatively small (separated medially above by about 2.9 times their radius). Ultimate maxillary palpomere small, elongate, nearly parallel-sided, convex at apex. Antennae extending to elytral two thirds; from antennomere 3 flattened, serrate, antennomere 3 about 2.2 times longer than antennomere 2 and 1.2 times shorter than antennomere 4; antennomeres 3-11 with short erect pubescence.

Pronotum transverse, 1.5 times wider than long, trapezoidal, with noticeable anterior and long acute posterior angles, anterior margin relatively little produced forward (Fig. 153). Scutellum square, slightly rounded at apex.

Elytra long (3.3 times as long as wide humerally), parallel-sided, with primary costa 4 more conspicuous in most of its length; other primary costae hardly distinguishable from secondary ones; interstices with double rows of small subquadrate cells. Pubescence uniform, short and decumbent.

Aedeagus with slightly widened and bent distally median lobe, provided with proximal "leg"; "leg" with bidentate distal process (Fig. 154).

Female. Similar to male, but eyes smaller, antennae shorter and less serrate.

Length: 4.8-7.2 mm. Width (humerally): $1.3-2.0 \mathrm{~mm}$.

ETYMOLOGY. The new species is named after Dr. O. Mosolov, who collected most of the type series.

DIAGNOSIS. P. mosolovi sp.n. is similar to $P$. subhumeralis Pic, 1923, distinguishable by the uniformly black antennae; the new species differs from $P$. amazonensis sp.n. by the testaceous posterior pronotal margin, as well as by the presence of a "leg" in the basal portion of the median lobe of the aedeagus and its more bent apex (Fig. 154).

\section{Plateros nautaensis Kazantsev sp.n. Figs 155-156}

MATERIAL: Holotype, $\mathrm{O}^{7}$, Peru, R. Morannon, $30 \mathrm{~km} \mathrm{NW}$ Nauta, Buen Fin, 6-8.II.1997, A. Petrov leg. (ICCM).

DESCRIPTION. Male. Black. Pronotal anterior and lateral margins, elytral shoulders, transverse band distad of middle and outer margin between them, trochanters and profemurs proximally testaceous.

Head dorsally with inconspicuous roundish impression behind antennal prominence, antennal sockets almost contiguous. Eyes relatively large (separated medially above by about 1.25 times their radius). Ultimate maxillary palpomere small, only slightly longer than wide, widest at middle. Antennae extending to elytral two thirds; from antennomere 3 flattened, strongly serrate, antennomere 3 about twice as long as antennomere 2 and 1.2 times shorter than antennomere 4; antennomeres 3-11 with short sparse erect pubescence.

Pronotum transverse, 1.4 times wider than long, with almost straight sides, noticeable anterior and acute posterior angles, anterior margin tringularly produced forward (Fig. 155). Scutellum square, truncate at apex.

Elytra long (3.2 times as long as wide humerally), slightly widening behind shoulders, with four equally developed primary costae; interstices with double rows of subquadrate cells. Pubescence uniform, short and decumbent.

Aedeagus with relatively slender median lobe, semicircularly bent distally and bidentate in preapical area (Fig. 156).

Length: $6.8 \mathrm{~mm}$. Width (humerally): $1.7 \mathrm{~mm}$.

Female. Unknown.

ETYMOLOGY. The name of the new species is derived from the locality, where the unique type specimen was collected.

DIAGNOSIS. P. nautaensis sp.n. differs from the similarly coloured P. enormis Kazantsev, 2005 [= irregularis Pic, 1923, homonym] only by the male genital structures (Fig. 156).

\section{Plateros piger Kazantsev sp.n. \\ Figs $157-158$}

MATERIAL: Holotype, $\sigma^{7}$, Ecuador, Orellana, Yasuni Res. Stn, 11-26.VII.2008, A. Tishechkin leg. (ICCM); paratypes: $2+0$, Ecuador, Orellana, Tiputini Biol. Stn, 0 $0^{\circ} 39.5^{\prime} \mathrm{S} 76^{\circ} 26^{\prime} \mathrm{W}, 28$.VII3.VIII.2008, A. Tishechkin leg. (ICCM).

DESCRIPTION. Male. Black. Pronotal lateral margins, elytral shoulders, transverse band distad of middle and outer margin between them, trochanters and femurs proximally testaceous.

Head dorsally with two small round impression behind antennal prominence, antennal sockets almost contiguous. Eyes relatively small (separated medially above by about 1.5 times their radius). Ultimate maxillary palpomere small, elongate, nearly parallel-sided, convex at apex. Antennae extending to elytral three fifths; from antennomere 3 flattened, flabellate, flabellae about as long as antennomeres, antennomere 3 about 2.4 times longer than antennomere 2 and 1.5 times shorter than antennomere 4; antennomeres 3-11 with short sparse erect pubescence.

Pronotum transverse, 1.3 times wider than long, trapezoidal, with inconspicuous anterior and acute posterior angles, anterior margin somewhat triangularly produced forward (Fig. 157). Scutellum square, slightly emarginate at apex.

Elytra long (3.4 times as long as wide humerally), flattened, parallel-sided, with four prominent equally developed primary costae; interstices with double rows of small roundish cells. Pubescence uniform, short and decumbent.

Aedeagus with relatively robust, slightly widened and bent distally median lobe (Fig. 158).

Female. Similar to male, but eyes smaller, antennae shorter and only serrate.

Length: 6.8-7.6 mm. Width (humerally): $1.6-1.9 \mathrm{~mm}$.

ETYMOLOGY. The name of the new species is derived from the Latin for "sluggish", alluding to the way the netwinged beetles move.

DIAGNOSIS. $P$. piger sp.n. is similar to $P$. nautaensis sp.n., distinguishable by the less transverse pronotum, as well as by the more robust, more distally widened median lobe of the aedeagus, which is not semicircularly bent in apical part (Fig. 158).

\section{Plateros pirana Kazantsev sp.n. Figs 158-160}

MATERIAL: Holotype, $\sigma^{7}$, Ecuador, Orellana, Yasuni Res. Stn, 11-26.VII.2008, A. Tishechkin leg. (ICCM); paratypes: $3 \sigma^{7} \sigma^{7}$, same label; 2 90, Ecuador, Orellana, Yasuni N.P., Via Maxus at Queb, Piraña Bridge, $0^{\circ} 39.5^{\prime} \mathrm{S} 76^{\circ} 26^{\prime} \mathrm{W}, 14-24$.VII.2008, A. Tishechkin leg.; O' $^{\top}$ Ecuador, Orellana, Tiputini Biol. Stn, $0^{\circ} 39.5^{\prime} \mathrm{S} 76^{\circ} 26^{\prime} \mathrm{W}$, 28.VII-3.VIII.2008, A. Tishechkin leg. (ICCM).

DESCRIPTION. Male. Dark brown. Proximal palpomeres, antennomeres 10-11, pronotal lateral margins, elytral shoulders and transverse band distad of middle, trochanters and femurs proximally testaceous.

Head dorsally flat behind antennal prominence, antennal sockets almost contiguous. Eyes moderately large (separated medially above by about 1.5 times their radius). Ultimate maxillary palpomere small, elongate, widest at middle. Antennae extending to elytral two thirds; from antennomere 3 flattened, strongly serrate, antennomere 3 about 2.6 times longer than antennomere 2 and 1.5 times shorter than antennomere 4; antennomeres 3-11 with short erect pubescence and longer distal bristles.

Pronotum transverse, 1.4 times wider than long, with almost straight sides, inconspicuous anterior and long acute posterior angles, anterior margin broadly rounded (Fig. 159). Scutellum square, truncate at apex. 


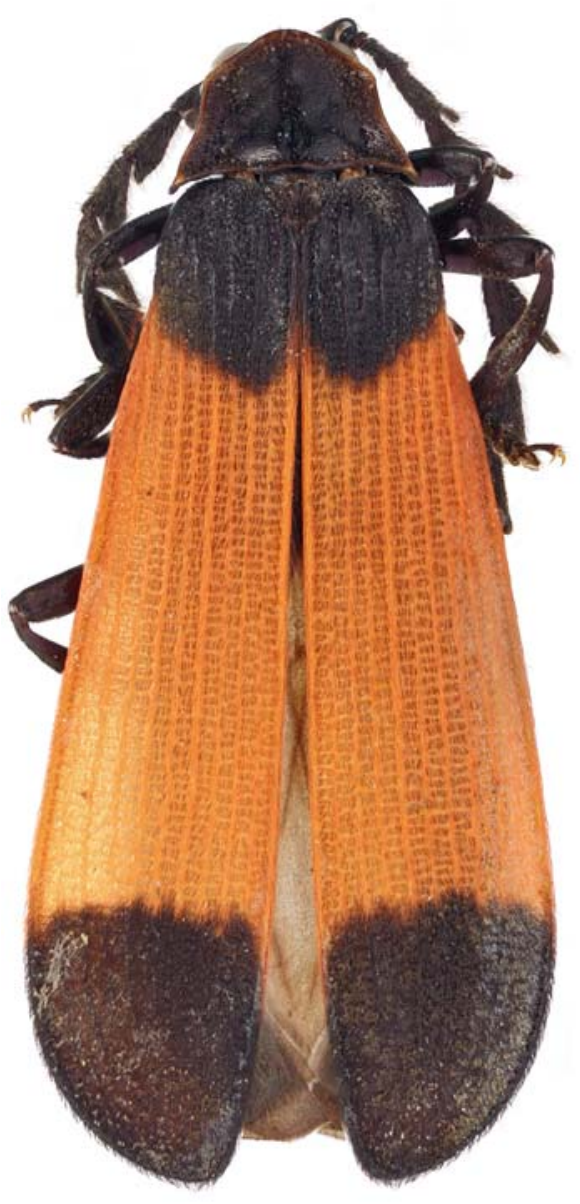

161

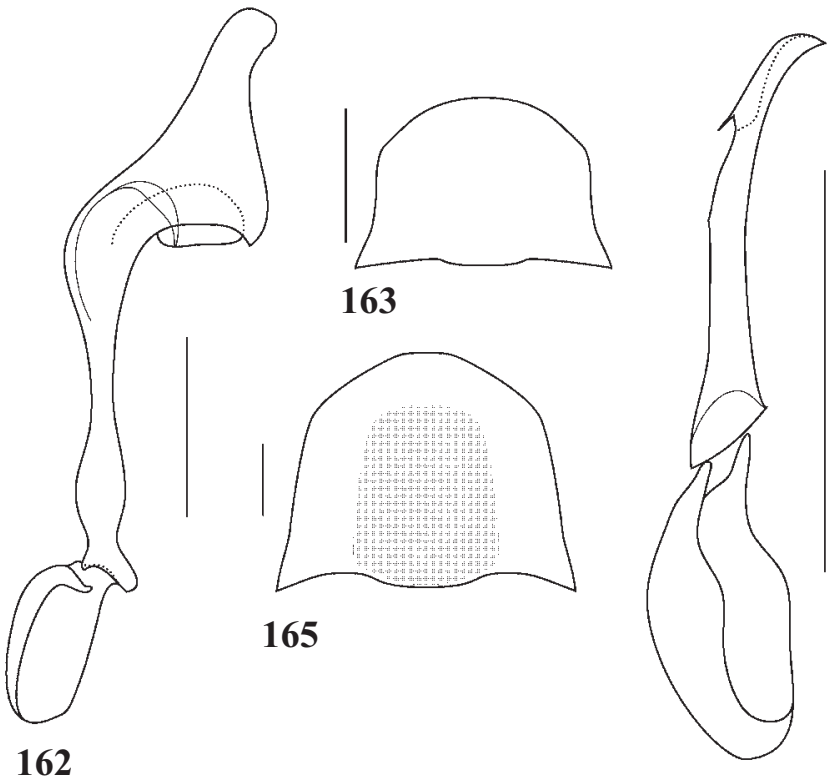

162

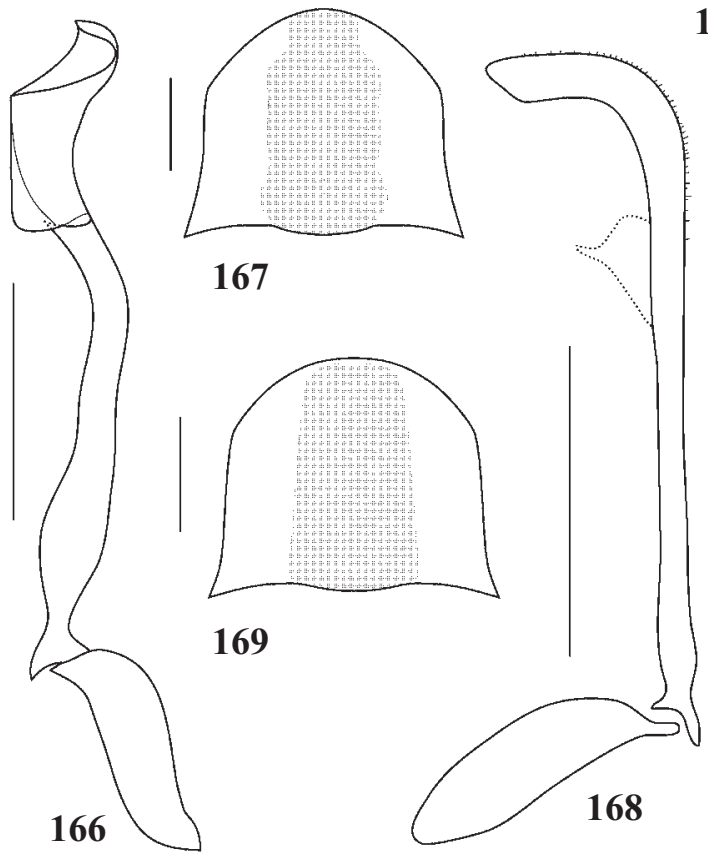

164

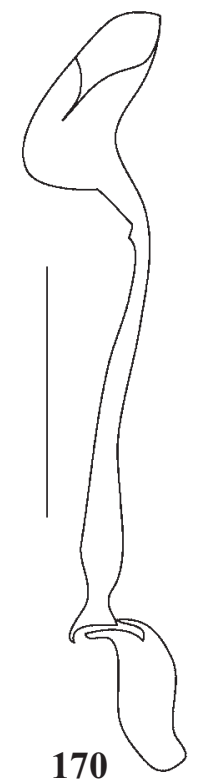

Figs 161-170. General view and details of Plateros spp., holotypes males: 161-162 - P. speciosus sp.n.; 163-164 - P. tartarus sp.n.; 165-166 - P. tiputiniensis sp.n.; 167-168 - P. yasuniensis sp.n.; 168-170 - P. zakharovi sp.n.; 161 - general view $(1=11.9 \mathrm{~mm}) ; 163$, $165,167,169$ - pronotum; 162, 164, 166, 168, 170 - aedeagus. Scale bar: $5 \mathrm{~mm}$.

Рис. 161-170. Общий вид и детали строения Plateros spp., голотипы, самцы: 161-162 — P. speciosus sp.n.; 163-164 — P. tartarus sp.n.; 165-166 - P. tiputiniensis sp.n.; 167-168 - P. yasuniensis sp.n.; 168-170 - P. zakharovi sp.n.; 161 - общий вид (1=11.9 мм); $163,165,167,169$ - переднеспинка; 162, 164, 166, 168, 170 - эдеагус. Масштабная линейка: 5 мм.

Elytra long (3.3 times as long as wide humerally), flattened, parallel-sided, with primary costae 2 and 4 more prominent; interstices with double rows of small roundish or pentagonal cells. Pubescence uniform, short and decumbent.

Aedeagus with slender, evenly curved median lobe, provided with dent in preapical part (Fig. 160).

Female. Similar to male, but eyes somewhat smaller, antennal pubescence decumbent.

Length: 6.2-9.0 mm. Width (humerally): 1.7-2.6 mm.
ETYMOLOGY. The name of the new species is derived from the Spanish noun meaning "piranha", as part of the type series was collected in the vicinities of the Piraña Bridge in Yasuni National Park in Ecuador.

DIAGNOSIS. P pirana sp.n. is similar to $P$. nautaensis sp.n., distinguishable by the testaceous two terminal antennomeres and slender, evenly curved median lobe of the aedeagus with a dent in its preapical part (Fig. $160)$. 


\section{Plateros speciosus Kazantsev sp.n.} Figs 161-162

MATERIAL: Holotype, $\sigma^{7}$, Peru, Huanuco, nr. Chinchao, 700 m, 18.VIII.1988, Zakharov leg. (ICCM).

DESCRIPTION. Male. Black. Narrow pronotal margins light brown; elytral transverse band occupying ca. half their length reddish orange.

Head dorsally with conspicuous transverse impression behind antennal prominence, antennal sockets almost contiguous. Eyes moderately large (separated medially above by about 1.3 times their radius). Ultimate maxillary palpomere relatively robust, elongate, widest at middle, convex at apex. Antennae extending to elytral two thirds; from antennomere 3 flattened, strongly serrate (Fig. 161), antennomere 3 about 1.6 times longer than antennomere 2 and 1.6 times shorter than antennomere 4; antennomeres 3-11 with short semierect pubescence and longer distal bristles.

Pronotum transverse, 1.4 times wider than long, trapezoidal, with conspicuous anterior and long acute posterior angles, anterior margin triangularly produced forward, posterior margin bisinuate (Fig. 161). Scutellum elongate, parallelsided, truncate at apex.

Elytra long (3.8 times as long as wide humerally), widening behind shoulders, widest in distal fourth, with four almost equally developed primary costae, hardly distinguishable from secondary ones in posterior half; interstices with double rows of mostly rectangular transverse cells. Pubescence uniform, short and decumbent.

Aedeagus with relatively robust, slightly bent distally median lobe, provided with apical helmet-like dilatation (Fig. 162).

Length: $11.9 \mathrm{~mm}$. Width (humerally): $2.7 \mathrm{~mm}$.

Female. Unknown.

ETYMOLOGY. The name of the new species is derived from the Latin for "handsome", alluding to its nice appearance.

ETYMOLOGY. The name of the new species is derived from the country, where the

DIAGNOSIS. P. speciosus sp.n. does not resemble any of the Plateros species of the area due to the broad reddish orange band on its elytra (Fig. 161), as well as the male genital structures (Fig. 162).

\section{Plateros tartarus Kazantsev sp.n. Figs 163-164}

MATERIAL: Holotype, ơ, Ecuador, Orellana, Yasuni N.P., Via Maxus at Queb, Pirana Bridge, 0³9.5'S 76²6'W, 14 24.VII.2008, A. Tishechkin leg. (ICCM).

DESCRIPTION. Male. Black. Proximal palpomeres, trochanters and femurs proximally yellow testaceous.

Head dorsally with small round impression behind antennal prominence, antennal sockets almost contiguous. Eyes relatively small (separated medially above by about 2.3 times their radius). Ultimate maxillary palpomere robust, only slightly longer than wide, conspicuously widened and convex distally. Antennae relatively narrow, tapering distally, extending to elytral three fourths; from antennomere 3 flattened, lightly serrate, antennomere 3 about 1.5 times longer than antennomere 2 and 2 times shorter than antennomere 4 ; antennomeres 3-11 with short semi-erect pubescence and longer distal bristles.

Pronotum transverse, 1.5 times wider than long, with almost straight sides, noticeable anterior and small acute posterior angles, anterior margin broadly rounded (Fig. 163). Scutellum square, feebly emarginate at apex.

Elytra long (3.6 times as long as wide humerally), parallel-sided, with four equally developed primary costae; inter- stices with double rows of mostly pentagonal cells. Pubescence uniform, short and semi-erect.

Aedeagus with straight, slender and short median lobe (Fig. 164)

Length: $4.5 \mathrm{~mm}$. Width (humerally): $1.1 \mathrm{~mm}$.

Female. Unknown.

ETYMOLOGY. The name of the new species is derived from the Latin for "hell", alluding to its almost uniformly black coloration.

DIAGNOSIS. $P$. tartarus sp.n. approaches $P$. atricolor Pic, 1923 of similar coloration pattern, but differs by the black coxae and yellow testaceous trochanters, as well as by the straight, slender and short median lobe of the aedeagus (Fig. 164).

\section{Plateros tiputiniensis Kazantsev sp.n.} Figs 165-166

MATERIAL: Holotype, $\sigma^{7}$, Ecuador, Orellana, Tiputini Biol. Stn, 0 39.5'S 76²6' W, 28.VII-3.VIII.2008, A. Tishechkin leg. (ICCM); paratype,, , same label (ICCM).

DESCRIPTION. Male. Black. Labrum, frons, pronotal anterior and lateral margins, elytral shoulders and transverse band distad of middle, trochanters and femurs proximally testaceous.

Head dorsally with inconspicuous roundish impression and two small longitudinal furrows behind antennal prominence, antennal sockets almost contiguous. Eyes moderately large (separated medially above by about 1.6 times their radius). Ultimate maxillary palpomere small, elongate, slightly widening distally and convex at apex. Antennae broad, extending to elytral three fourths; from antennomere 3 flattened, strongly serrate, antennomere 3 about twice as long as antennomere 2 and 1.25 times shorter than antennomere 4; antennomeres 3-11 with short erect pubescence and longer distal bristles.

Pronotum transverse, 1.25 times wider than long, slightly trapezoidal, with rounded pronounced and acute prominent posterior angles, anterior margin triangularly produced forward, posterior margin bisinuate; surface with dense short decumbent pubescence (Fig. 165). Scutellum square, feebly emarginate at apex.

Elytra moderately long (3.1 times as long as wide humerally), parallel-sided, flattened, with primary costa 4 more prominent in proximal half; interstices with double rows of small subquadrate cells. Pubescence uniform, short and decumbent.

Aedeagus nearly symmetrical, with slender, bidentate apically median lobe (Fig. 166).

Length: 8.6-9.5 mm. Width (humerally): 2.3-2.4 mm.

Female. Similar to male, but antennomeres 3-10 less serrate.

ETYMOLOGY. The name of the new species is derived from the locality, where the small type series was collected.

DIAGNOSIS. P. tiputiniensis sp.n. is similar to $P$. nautaensis sp.n., distinguishable by the conspicuously pubescent pronotum and straighter and differently arranged distally median lobe of the aedeagus (Fig. 166).

\section{Plateros yasuniensis Kazantsev sp.n.}

Figs 167-168

MATERIAL: Holotype, $\sigma^{7}$, Ecuador, Orellana, Yasuni Res. Stn, 11-26.VII.2008, A. Tishechkin leg. (ICCM); paratype, $\sigma^{7}$, same label (ICCM).

DESCRIPTION. Male. Black. Labrum, pronotal lateral margins, elytral shoulders and transverse band distad of middle, trochanters and femurs proximally testaceous. 


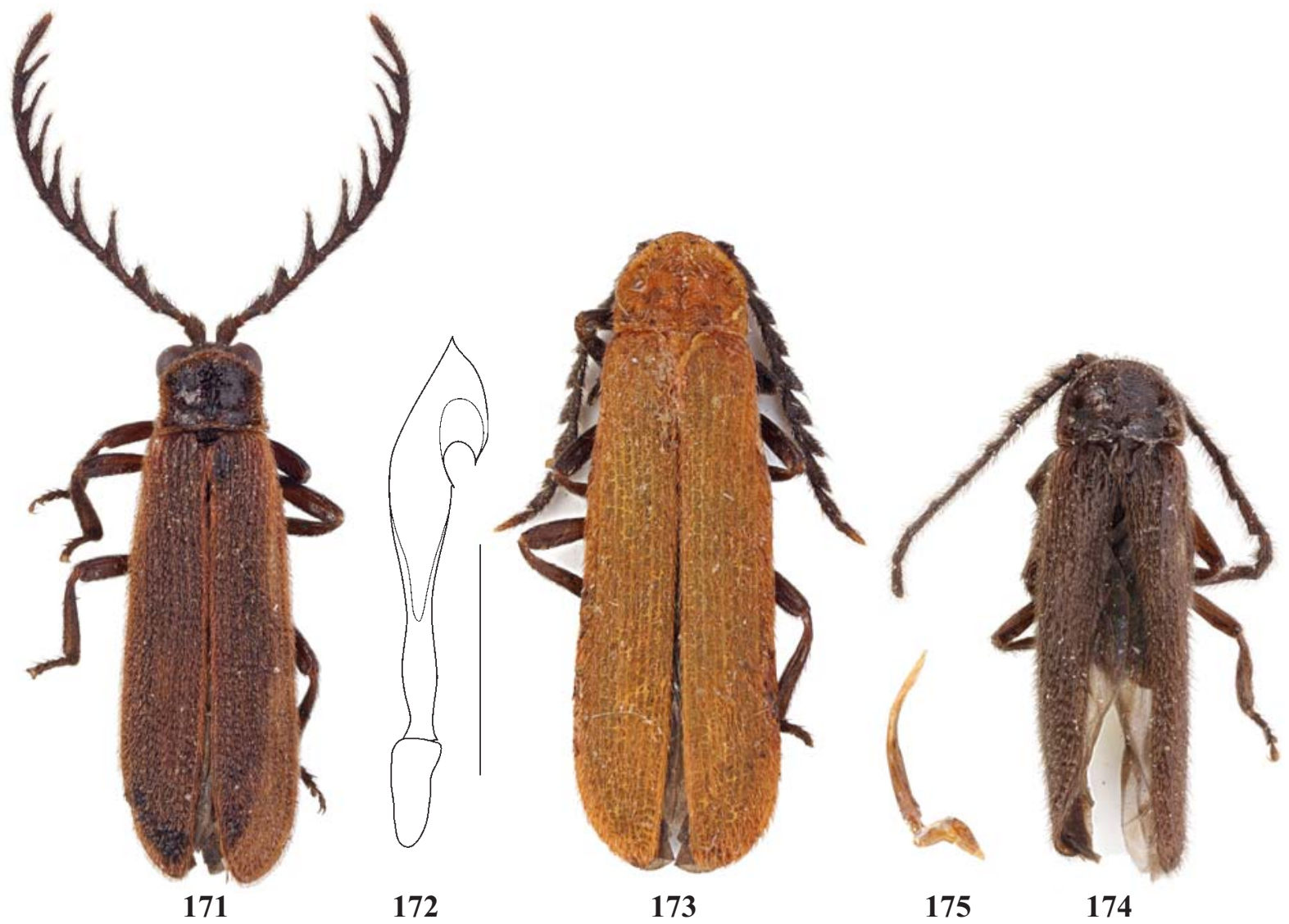

Figs 171-175. General view and details of Plateros spp., lectotypes: $171-172-P$. donckieri $(1=5.9 \mathrm{~mm}) ; 173-P$. nathani $(1=8.0$ $\mathrm{mm}) ; 174-175-P$. nitidus $(1=4.7 \mathrm{~mm}) ; 171-172,174-175$ - males; 173 - female; 171, 173-174 - general view; 172,175 - aedeagus. Scale bar: $5 \mathrm{~mm}$.

Рис. 171-175. Общий вид и детали строения Plateros spp., лектотипы: 171-172 - P. donckieri $(1=5.9$ мм); 173 - P. nathani $(1$ $=8.0$ мм $) ; 174-175-P$. nitidus $(1=4.7$ мм $) ; 171-172,174-175$ - самцы; 173 - самка; 171, 173-174 - общий вид; 172, 175 — эдеагус. Масштабная линейка: 5 мм.

Head dorsally with inconspicuous roundish impression and two small longitudinal furrows behind antennal prominence, antennal sockets almost contiguous. Eyes moderately large (separated medially above by about 1.6 times their radius). Ultimate maxillary palpomere small, elongate, slightly widening distally and convex at apex. Antennae tapering distally, extending to elytral two thirds; antennomeres 3-7 flattened and serrate, antennomere 3 about twice as long as antennomere 2 and 1.25 times shorter than antennomere 4; antennomeres 3-11 with short sparse erect pubescence and longer distal bristles.

Pronotum transverse, 1.2 times wider than long, with almost straight sides, noticeable anterior and acute posterior angles, anterior margin narrowly rounded (Fig. 167). Scutellum square, slightly rounded at apex.

Elytra long (3.75 times as long as wide humerally), parallel-sided, with four almost equally developed primary costae; interstices with double rows of small roundish cells. Pubescence uniform, short and decumbent.

Aedeagus with straight hooked distally median lobe, provided with minute bristles in apical part (Fig. 168).

Length: $6.8-7.2 \mathrm{~mm}$. Width (humerally): $1.6-1.7 \mathrm{~mm}$.

Female. Unknown.

ETYMOLOGY. The name of the new species is derived from the national park, where the type series was collected.

DIAGNOSIS. P. yasuniensis sp.n. is similar to $P$. nautaensis sp.n., distinguishable by the hockey stick-like median lobe of the aedeagus with minute bristles in its apical part (Fig. 168).

\section{Plateros zakharovi Kazantsev sp.n. Figs 168-170}

MATERIAL: Holotype, $0^{7}$, Peru, $60 \mathrm{~km}$ W Pucallpa, Stn Ivita, 25-31.III.1988, Zakharov leg. (ICCM); paratypes: + , Peru, $60 \mathrm{~km} \mathrm{~W}$ Pucallpa, Stn Ivita, II.1988, Zakharov leg.; + , Peru, Huanuco, 40 km NNW Tingo Maria, Sta Marta, 1200 m, 15-16.IV.2008, O. Mosolov leg. (ICCM).

DESCRIPTION. Male. Black. Pronotal narrow anterior margin and broad lateral sides, elytral last interstice and transverse band at middle, interrupted by suture, trochanters and femurs proximally testaceous.

Head dorsally with inconspicuous transverse impression and two small longitudinal furrows behind antennal prominence, antennal sockets almost contiguous. Eyes relatively small (separated medially above by about 1.8 times their radius). Ultimate maxillary palpomere small, elongate, narrowing distally. Antennae extending to elytral two thirds; from antennomere 3 flattened, serrate, antennomere 3 about 2.8 times longer than antennomere 2 and 1.3 times shorter than antennomere 4 ; antennomeres 3-11 with relatively long semi-erect pubescence.

Pronotum transverse, 1.25 times wider than long, with almost straight sides, conspicuous anterior and small acute posterior angles, anterior margin rounded (Fig. 169). Scutellum square, truncate at apex. 
Elytra long (3.3 times as long as wide humerally), parallelsided, with primary costa 4 noticeably more elevated in proximal two thirds; interstices with double rows of small pentagonal or roundish cells. Pubescence uniform, short and decumbent.

Aedeagus with slender, conspicuously dilated and flattened distally median lobe (Fig. 170).

Female. Similar to male, but antennomeres 3-10 less serrate.

Length: 5.7-6.0 mm. Width (humerally): $1.4-1.5 \mathrm{~mm}$.

ETYMOLOGY. The new species is named after Dr. Zakharov, who collected part of the type series.

DIAGNOSIS. P. zakharovi sp.n. is similar to P. nautaensis sp.n., distinguishable by the smaller size, less serrate antennae and dilated and flattened distally median lobe (Fig. 170).

Plateros bifoveiceps (Pic, 1921)

Ditoneces bifoveiceps Pic, 1921: 4

MATERIAL: Lectotype, hereby designated, O7, [Vietnam], "HoaBinh, Tonkin", "Ditoneces bifoveiceps Pic" [Pic's manuscript labels] (MNHN); paralectotype, hereby designated,, , same pin (MNHN).

REMARKS. As Pic's [1921] description does not indicate the uniqueness of specimens, a lectotype and a paralectotype of Plateros bifoveiceps is hereby designated in compliance with the ICZN to clarify the application of the name to a taxon.

\section{Plateros donckieri (Pic, 1923)}

Figs 171-172

Ditoneces donckieri Pic, 1923: 49

MATERIAL: Lectotype, hereby designated, $\sigma^{\top}$, [Vietnam], "HoaBinh, Tonkin" [printed], "Ditoneces donckieri n.sp." [Pic's manuscript label] (MNHN)

REMARKS. As Pic's [1923] description does not indicate the uniqueness of the specimen, the lectotype of Plateros donckieri is hereby designated in compliance with the ICZN to clarify the application of the name to a taxon. It is possible that part of the distal portion of the aedeagus of the Lectotype is missing (Fig. 172).

\section{Plateros nathani Pic, 1943}

Fig. 173

Plateros nathani Pic, 1943: 5

MATERIAL: Lectotype, hereby designated,, , [S India], "Coimba Yok, mars [18]93" [Pic's manuscript label], "Nathani n.sp.' [Pic's manuscript label] (MNHN)

REMARKS. As Pic's [1943] description does not indicate the uniqueness of the specimen, the lectotype of Plateros nathani is hereby designated in compliance with the ICZN to clarify the application of the name to a taxon.

\section{Plateros nitidus Pic, 1938}

Figs 174-175

Plateros nitidus Pic, 1938: 160

MATERIAL: Lectotype, hereby designated, $O^{\top}$, [Vietnam], "Hoa Binh" [Pic's manuscript label], "P. nitidus n.sp." [Pic's manuscript label] (MNHN)

REMARKS. As Pic's [1938] description does not indicate the uniqueness of the specimen, the lectotype of Plateros nitidus is hereby designated in compliance with the ICZN to clarify the application of the name to a taxon.

Plateros planatus Waterhouse, 1879

Plateros planatus Waterhouse, 1879: 27

Plateros fulgens Kleine, 1933: 20

Ditoneces hoanus Pic, 1926: 32, syn.n.

Ditoneces incisicollis Pic, 1921: 5

Plateros koreanus Kleine, 1936: 263

Ditoneces pallidus Pic, 1921: 5, syn.n.

Plateros purus Kleine, 1926: 99

Ditoneces sulcatithorax Pic, 1925: 18
Plateros tuberculatus Pic, 1921: 6

MATERIAL: Lectotype of Ditoneces pallidus Pic, hereby designated, $O^{7}$, [China], "Chang Hai" [manuscript label], "Ditoneces ㅇ sp. nov." [manuscript label], "pallidus n.sp." [Pic's manuscript label] (MNHN); Lectotype of Ditoneces hoanus Pic, hereby designated, $\sigma^{7}$, [Vietnam], "Hoa Binh" [manuscript label], "Ditoneces hoanus n.sp." [Pic's manuscript label] (MNHN).

REMARKS. As Pic's [1921-1922; 1926] descriptions do not indicate the uniqueness of specimens, lectotypes of $\mathrm{Di}$ toneces pallidus and Ditoneces hoanus are hereby designated in compliance with the International Code of Zoological Nomenclature to clarify the application of a name to a taxon. The lectotype of Ditoneces pallidus, although labelled as female, is in fact a male specimen of Plateros planatus Waterhouse, 1879; the lectotype of Ditoneces hoanus is another specimen of the same taxon. Therefore, Ditoneces pallidus Pic, 1921, syn.n. and Ditoneces hoanus Pic, 1926, syn.n. are put in synonymy with Plateros planatus Waterhouse, 1879.

Plateros tumacacori Green, 1953

Plateros tumacacori Green, 1953: 155

Plateros rocioae Zaragoza, 1999: 53, syn.n.

REMARKS. Comparison of the male genitalia and descriptions of $P$. tumacacori Green and $P$. rocioae Zaragoza demonstrates that the two taxa belong to a single species. Hence, Plateros rocioae Zaragoza, 1999, syn.n. becomes a synonym of the older taxon.

The following new names are proposed to replace existing younger homonyms:

Plateros afroguineensis nom.n. pro Plateros guineensis Kazantsev, 1997: 11, nec Plateros guineensis (Pic, 1921): 2 (Graciloplateros).

Plateros alitecostatus nom.n. pro Plateros diversecostatus Pic, 1942: 6, nec Plateros diversecostatus (Pic, 1922): 22 (Calleros).

Plateros angus nom.n. pro Plateros angustatus (Pic, 1939): 165 (Calleros), nec Plateros angustatus (Pic, 1926): 23 (Melampyrus).

Plateros antennifer nom.n. pro Plateros antennalis Kleine 1930: 167, nec Plateros antennalis Bourgeois, 1882: 144.

Plateros atrosuturalis nom.n. pro Plateros nigrosuturalis (Kleine, 1931): 275 (Ditoneces), nec Plateros nigrosuturalis (Pic, 1921): 5 (Microditoneces).

Plateros balabacensis nom.n. pro Plateros balabacanus (Pic, 1929): 73 (Ditoneces), nec Plateros balabacanus (Pic, 1921): 2 (Microplateros).

Plateros bicoloricrus nom.n. pro Plateros bicoloripes Pic, 1943: 14, nec Plateros bicoloripes (Pic, 1923): 74 (Planeteros). Plateros bocakovae nom.n. pro Plateros prominens (Bocakova, 1997): 208 (Melaneros), nec Plateros prominens Kleine, 1940: 895.

Plateros brunneorufus nom.n. pro Plateros rufobrunneus (Gorham, 1882): 5 (Ditoneces), nec Plateros rufobrunneus (Gorham, 1881): 26 (Calleros).

Plateros caballeroi nom.n. pro Plateros aterrimus Zaragoza, 1999: 26, nec Plateros aterrimus (Gorham, 1884): 244 (Calleros). Plateros ciceroi nom.n. pro Plateros tonkineus (Pic, 1931): 97 (Ditoneces), nec Plateros tonkineus Pic, 1926: 31.

Plateros constantini nom.n. pro Plateros marseuli (Pic, 1934): 33 (Calleros), nec Plateros marseuli Pic, 1923: 32. Plateros cristifer nom.n. pro Plateros pectinicornis (Pic,

1932): 5 (Calleros), nec Plateros pectinicornis Pic, 1923: 33. Plateros curtilinaris nom.n. pro Plateros curtelineatus (Pic,

1934): 134 (Calleros), nec Plateros curtelineatus Pic, 1926: 31. Plateros duomaculatus nom.n. pro Plateros bimaculatus Pic, 1922: 22 (Calleros), nec Plateros bimaculatus (Kirsch, 1873): 386 (Eros). 
Plateros elegans nom.n. pro Plateros mundus Kleine, 1949: 13, nec Plateros mundus (Kleine, 1931): 288 (Ditoneces). Plateros fuliganus nom.n. pro Plateros fuliginosus (Pic, 1934):

134 (Calleros), nec Plateros fuliginosus Kleine, 1930: 345.

Plateros gorhamianus nom.n. pro Plateros gorhami Zaragoza, 1999: 37, nec Plateros gorhami (Pic, 1921): 3 (Ditoneces).

Plateros hoabinhensis nom.n. pro Plateros binhanus Pic, 1925: 10, nec Plateros binhanus (Pic, 1925): 73 (Ditoneces). Plateros laditatus nom.n. pro Plateros dilatatus (Bocakova, 1997): 219 (Melaneros), nec Plateros dilatatus (Pic, 1926): 23 (Calleros)

Plateros maculaticrus nom.n. pro Plateros maculatipes (Pic, 1934): 122 (Calleros), nec Plateros maculatipes (Pic, 1926): 33 (Ditoneces).

Plateros mauricei nom.n. pro Plateros donckieri (Pic, 1934): 33 (Calleros), nec Plateros donckieri (Pic, 1923): 49 (Ditoneces).

Plateros miladae nom.n. pro Plateros gressitti (Bocakova, 1997): 203 (Melaneros), nec Plateros gressitti Nakane, 1971: 147.

Plateros nakanei nom.n. pro Plateros latevittatus Nakane, 1983: 120, nec Plateros latevittatus (Pic, 1934): 33 (Calleros).

Plateros nigrosutus nom.n. pro Plateros nigrosuturalis Kleine, 1939: 13, nec Plateros nigrosuturalis (Pic, 1921): 5 (Microditoneces).

Plateros parabolus nom.n. pro Plateros parallelus (Pic, 1928): 57 (Calleros), nec Plateros parallelus Gorham, 1880: 22.

Plateros pullatus nom.n. pro Plateros nigricolor Pic, 1943: 18, nec Plateros nigricolor (Pic, 1932): 5 (Calleros).

Plateros reductefasciatus nom.n. pro Plateros subfasciatus (Pic, 1934): 128 (Calleros), nec Plateros subfasciatus (Pic, 1930): 84 (Calleros).

Plateros semang nom.n. pro Plateros malaccanus (Pic, 1928): 15 (Ditoneces), nec Plateros malaccanus (Pic, 1921): 3 (Cautirodes).

Plateros simulus nom.n. pro Plateros simulator Kazantsev, 2005: 244, nec Plateros simulator Kleine, 1929: 250

Plateros subductor nom.n. pro Plateros subreductus (Pic, 1942): 5 (Ditoneces), nec Plateros subreductus (Pic, 1934): 33 (Calleros).
Plateros sumatrensis nom.n. pro Plateros longipennis (Pic, 1926): 34 (Libnetomorphus), nec Plateros longipennis (Pic, 1921): 6 (Melampyrus).

Plateros suturalissimus nom.n. pro Plateros longesuturalis (Pic, 1932): 255 (Calleros), nec Plateros longesuturalis (Pic, 1921): 5 (Microditoneces).

Plateros villosus nom.n. pro Plateros pilosus (Pic, 1934):

134 (Calleros), nec Plateros pilosus Kleine, 1926: 48.

Plateros zaragozai nom.n. pro Plateros falcatus Zaragoza, 1999: 24, nec Plateros falcatus (Bocakova, 1997): 205 (Melaneros)

The following new distributions are reported in Plateros:

Plateros hasegawai Nakane et Baba, 1961

Plateros hasegawai Nakane et Baba, 1961: 5

MATERIAL: $0^{7}$, South Kurils, Kunashir, env. Tretyakovo, 18 22.VII.1990, S. Kazantsev (ICCM)

REMARKS. This is the first record of Plateros hasegawai from Russia; the species was previously known only from Japan.

\section{Plateros veirsi Zaragoza, 1999}

Plateros veirsi Zaragoza, 1999: 28

MATERIAL: $120^{\prime}$ and $10 \%$, [USA], S[outh] W[estern] $\mathrm{R}$ [esearch] S[tation], $5 \mathrm{mi}$ W Portal, 5400 feet, Cochise Co., Arizona, 7.VII-9.VIII.1956, S. M. Cazier leg. (AMNH and ICCM).

REMARKS. This is the first record of Plateros veirsi from the USA; the species was previously known only from Mexico [Zaragoza, 1999].

\section{Biogeography}

The tribe Platerotini includes twelve genera, among them Plateros, one of the most species-rich in the family. Plateros is distributed in almost all biogeographical zones (Map 1) and in this respect is unique among the net-winged beetles. It has not been recorded only in the Western Palaearctic region, in the Greater Antilles, Madagascar, New Zealand and Melanesia/

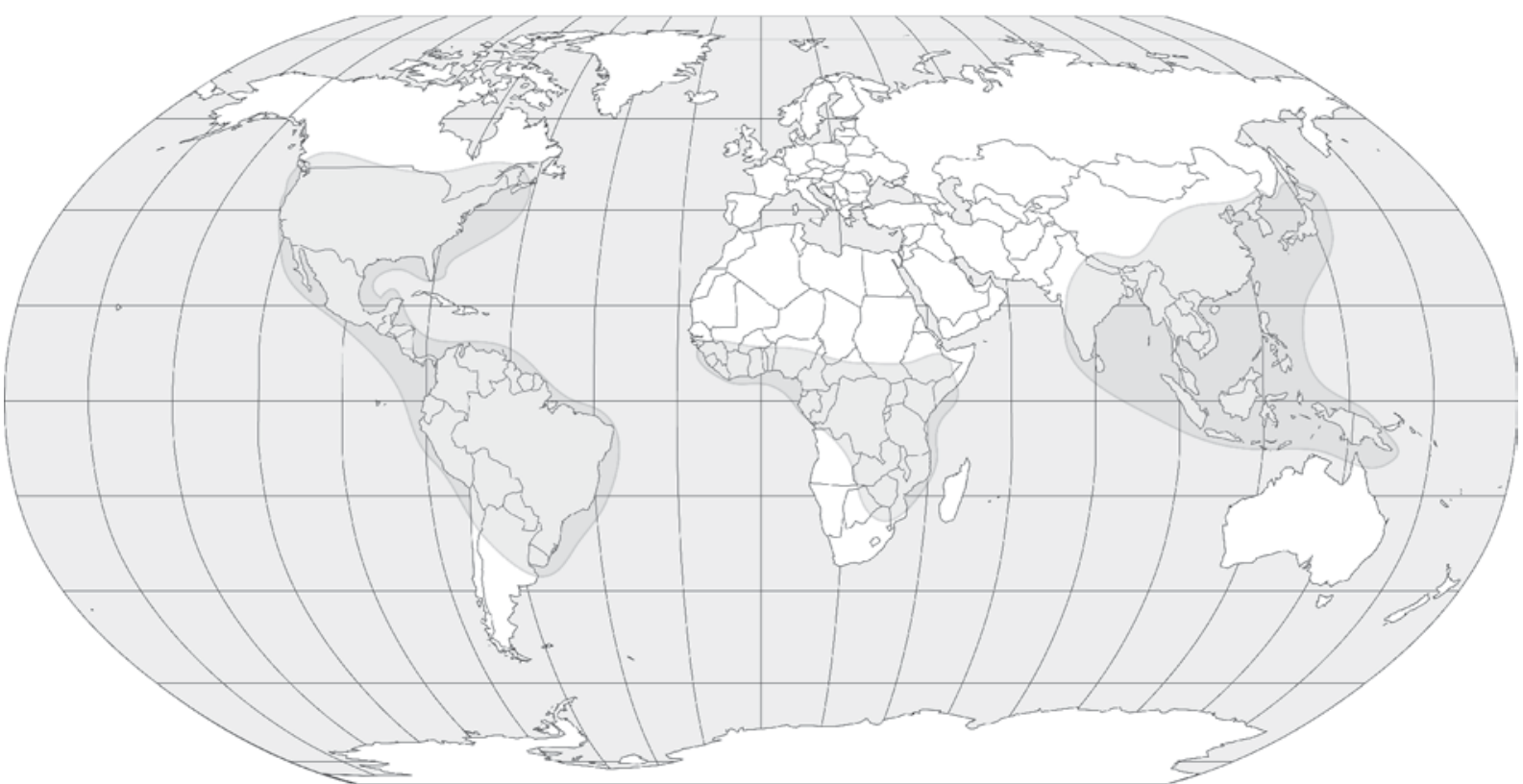

Map 1. World distribution of Plateros.

Карта 1. Ареал рода Plateros 
Polynesia. On the contrary, the other platerotine genera are confined to limited areas, in Central and mostly northern South America (Calolycus Gorham, 1881, Cavoplateros Pic, 1913, Euplateros gen.n., Falsocalleros Pic, 1933, Microlycus Pic, 1922, Neoplateros Kazantsev, 2006, Plateromimus Kazantsev, 2006, Paraplateros Zaragoza, 1999, stat.n., Teroplas Gorham, 1884, Ultroplateros Kazantsev, 2006) or in Sri Lanka and the Sunda Archipelago (Falsotrichalus Pic, 1921).

The absence of the tribe in the Greater Antilles, Madagascar and New Zealand seems to effectively exclude the probability of its across the water dispersal throughout the globe. The platerotines are virtually absent in Australia either, as the only species found on this continent originates from Queensland, where it was probably introduced from adjacent New Guinea relatively not so long ago through a land bridge.

Such distribution leads to two conclusions. First, the origin of the group should probably be placed in Central America, or on the land mass now making part of Central America, where the genus-group diversity is the highest. Second, given the continent drift theory is true, the emergence of platerotines should occur after the Pangaea split, as members of the group are absent or represent relatively recent intruders in fragments of former Lavrasia (e.g., in North America or East Asia), on the one hand, but prior to the Gondwana break-up, as platerotines occur on parts of both blocs that emerged after the first Gondwanaland split, on the other. The said split being the separation of Madagascar/India/New Guinea/Australia/Antarctica bloc ca. 200 (some studies suggest 150) million years ago, the tribe should be at least 200 (or 150) million years old. Of all fragments of this Gondwanaland bloc, however, the Platerotini, for one reason or another, seemed to survive only in India and New Guinea, moving to new territories therefrom through emerging land bridges.

ACKNOWLEDGEMENTS. I wish to express my gratitude to Dr. B. Brugge (Zoological Museum of Amsterdam University), Dr. C. Carlton and Dr. V. Bayless (Louisiana State University Arthropod Museum, Baton Rouge), Dr. P. Grootaert (Institut Royal de Sciences naturelles de Belgique, Bruxelles), Dr. M. Hartmann (Naturkundemuseum, Erfurt) and Dr. A. Kopetz (Krefeld, Germany), Dr. L. Herman (American Museum of Natural History, New York) and Dr. J. Menier (Muséum national d'Histoire naturelle, Paris), through whose courtesy I was able to study the Lycidae collections under their care. My sincere thanks are also due to Dr. D. Fedorenko (Moscow), Dr. R. Holyñski (Milanowek, Poland), Dr. O. Kabakov (S-Petersburg), Dr. O. Mosolov (Moscow), Dr. C.W. O'Brien (Green Valley, Arizona), Dr. A. Petrov (Moscow) and Dr. A. Tishechkin (Santa Barbara, California) for the interesting Platerotini material from various parts of Earth.

\section{References}

Bocáková M. 1997a. Revision of the genus Melaneros from China with a note on Ditoneces (Coleoptera, Lycidae) // Acta Soc. Zool. Bohem. Vol.61. P.175-190.

Bocáková M. 1997b. Revision and phylogenetic analysis of the genus Melaneros Fairmaire, 1877 (Coleoptera, Lycidae) from New Guinea // Entom. Basil. Vol.20. P.165-222.

Bocáková M. 2001. Revision and phylogenetic analysis of the subfamily Platerodinae (Coleoptera: Lycidae) // Eur. J. Entomol. Vol.98. P.53-85.

Kazantsev S. 1991. To the knowledge of oriental Lycidae (Coleoptera). Remarks on Lycidae of Himalaya // Entom. Basil. B.14. P.153-182.

Kazantsev S. 1997. Sur le sous-genre Planeteros (Coleoptera, Lycidae) // Rev. fr. d'Entom. (N.S.). Vol.19. Nos.1-2. P.7-17.

Kazantsev S. 2000. To the knowledge of the African subgenus Planeteros of the genus Melaneros (Coleoptera, Lycidae) // Beitr. Ent. B.5. H.1. S.103-118.

Kazantsev S. 2001. New species of the genus Melaneros Fairmaire, 1879 from Nepal, China and the USA (Coleoptera, Lycidae) // Russ. Entom. J. Vol.10. No.1. P.13-16.

Kazantsev S.V. 2005a. Contribution to the knowledge of the genus Plateros Bourgeois, 1879 (Lycidae, Coleoptera)// Russ. Entom. J. Vol.13. No.4 (2004). P.237-244.

Kazantsev S.V. 2005b. New and little known oriental species of Lycidae (Coleoptera) // Russ. Entom. J. Vol.14. No.1. P.21-28.

Kazantsev S.V. 2006a. Net-winged beetles of the genus Calolycus Gorham, 1881, with notes on Plateros Bourgeois, 1878 (Coleoptera: Lycidae) // Russ. Entom. J. Vol.14. No.3 (2005). P.203-208.

Kazantsev S.V. 2006b. A review of the genera Microlycus Pic, 1922 and Teroplas Gorham, 1884 (Coleoptera: Lycidae) // Russ. Entom. J. Vol.14. No.4 (2005). 275-280.

Kleine R. 1929. Neue Indische Lycidae nebst faunistischen Bemerkungen // Indian Forest Records. Vol.13. No.6 (1928). P.221-268, 5 tbs

Pic M. 1921-1922. Contribution à l'étude des Lycides // L'Echange, hors texte. Vol.37-38. Nos.404-410. P.1-28.

Pic M. 1923: Etude des Malacodermes de 1'Indochine recueillis par M.R.Vitalis de Salvaza // Faune Entomologique de 1' Indochine Française. Vol. 1. No.6. P.7-69.

Pic M. 1924-1939. Malacodermes exotiques // L'Echange, hors texte. Vol.40-55. Nos.418-477. P.1-472.

Pic M. 1943. (sans titre). Opuscula Martialia. Vol.9. P.7.

Zaragoza Cabaliero S. 1999. Cantharoidea (Coleoptera) de Mexico. III. El genero Plateros Bourgeois (Lycidae: Erotinae: Platerodini) // Acta Zool. Mex. (n.s.). Vol.78. P.1-71. 